\title{
16. SILICOFLAGELLATES AND SOME SPONGE SPICULES FROM THE SOUTHWEST PACIFIC, DEEP SEA DRILLING PROJECT, LEG 90
}

\author{
Sigurd Locker and Erlend Martini, Geologisch-Paläontologisches Institut der Universität, Frankfurt am Main ${ }^{2}$
}

\begin{abstract}
Silicoflagellates are described from Sites 588 (middle Eocene), 591 (middle Miocene to lower Pliocene), and 594 (middle Miocene to Quaternary) in the southwest Pacific. At Sites 591 and 594 a detailed silicoflagellate zonation is possible, although there are some obvious differences arising from the latitudinal position of the sites in the silicoflagellate assemblages. Comparison between the sequences recovered at Sites 591 and 206 (Leg 21) revealed two hiatuses in the latter, but helped to establish a zonation for this area from the lower Miocene to the Pleistocene and a correlation to standard nannoplankton zones. The stratigraphic implications of the taxonomy used by various authors and the species concept presented here are discussed in detail. Special reference is made to types described by Ehrenberg and to later synonyma, because the Ehrenberg collection is the base for all subsequent descriptions and evaluations of silicoflagellate taxa.

Two new genera (Neonaviculopsis, Paramesocena), two new subspecies (Dictyocha fibula subsp. asymmetrica, Neonaviculopsis neonautica subsp. praenautica), and three new forms (Dictyocha perlaevis $\mathrm{f}$. pentaradiata, Distephanus speculum subsp. speculum f. nonarius, and Mesocena ? hexalitha f. heptalitha) are described from the southwest Pacific Neogene and Pleistocene.

Associated sponge spicules were noted and will be described in detail in a later paper, but some are documented on Plate 13.
\end{abstract}

\section{INTRODUCTION}

During Leg 90 silicoflagellates and sponge spicules were found in three out of eight sites drilled in the New Caledonia to New Zealand region in the southwest $\mathrm{Pa}$ cific Ocean (Fig. 1). They are commonly associated with diatoms, radiolarians, ebridians, and actiniscidians.

Hole $588 \mathrm{C}$ yielded Middle Eocene silicoflagellates in the lowest core (Core 19). At Site 591 silicoflagellates are rather common in the middle Miocene to lower Pliocene, with the exception of the upper middle Miocene, where they do not occur or are rare. At Site 594 silicoflagellates occur from the middle Miocene through the Pleistocene and are investigated in detail in Holes 594 and 594A. As at Site 591, the upper middle Miocene contains only rare silicoflagellates compared with the general distribution at this site. Reworked silicoflagellates from the Paleogene were noted at various levels and are marked by an asterisk in Table 3 .

The assemblages of these sites and their age assignments are discussed below. Fossil lists for selected samples from Holes 588C, 591, 591A, 591B, 594, and 594A, and correlation to standard calcareous nannoplankton zones are presented in Tables 1 to 3, later. To obtain the abundances shown in these tables, a 120 -mm traverse was made across the slides. Five categories are used: 1 $=1$ specimen, $2=2$ to 5 specimens, $3=6$ to 15 specimens, $4=16$ to 50 specimens, $5=>50$ specimens.

\footnotetext{
${ }^{1}$ Kennett, J. P., von der Borch, C. C., et al., Init. Repts. DSDP, 90: Washington (U.S. Govt, Printing Office).

2 Addresses: (Locker, present address) Geologisch-Palãontologisches Institut der Universităt, Olshausenstr. 40-60, D-23 Kiel, Federal Republic of Germany; (Martini) Geologisch-Paläontologisches Institut der Universität, Senckenberg-Anlage 32-34, D-6000 Frankfurt am Main, Federal Republic of Germany.
}

Most silicoflagellate taxa described are documented by light microscopic photographs or by scanning electron microscope (SEM) pictures. Sponge spicules are not described in detail in this paper, but are documented by several photographs.

\section{SILICOFLAGELLATE ZONATION}

Investigations of various DSDP holes have shown that, with the exception of very few areas, the Paleogene silicoflagellate assemblages are relatively uniform in all oceans. But starting with the early to middle Miocene, distinct differentiation can be recognized between several regions of the oceans, especially between low and higher latitudes (Bukry, 1975; Ciesielski, 1975; Busen and Wise, 1977). This trend causes, in general, some difficulties in biostratigraphic correlations of Neogene sequences over long distances, for silicoflagellate assemblages that have different constituents and are adapted to warmer or cooler water conditions must be placed in somewhat different zonations. This is true for both the sections investigated from the southwest Pacific.

\section{Sites 591, 206}

The silicoflagellate zonation adopted here for the Neogene sequence at Site 591 is based on the stratigraphic occurrence of species which are found at Sites 591 and 206 (the latter investigated by Dumitrică, 1973b). The subdivision includes, from base to top, the Naviculopsis iberica Zone, Corbisema triacantha Zone, Dictyocha varia Zone, Neonaviculopsis neonautica neonautica Zone, Paramesocena circulus Zone, D. perlaevis Zone, and $D$. messanensis aculeata Zone (Fig. 2). Within the upper part of the C. triacantha Zone a Distephanus stauracanthus Horizon is distinguished and in the lower Quater- 


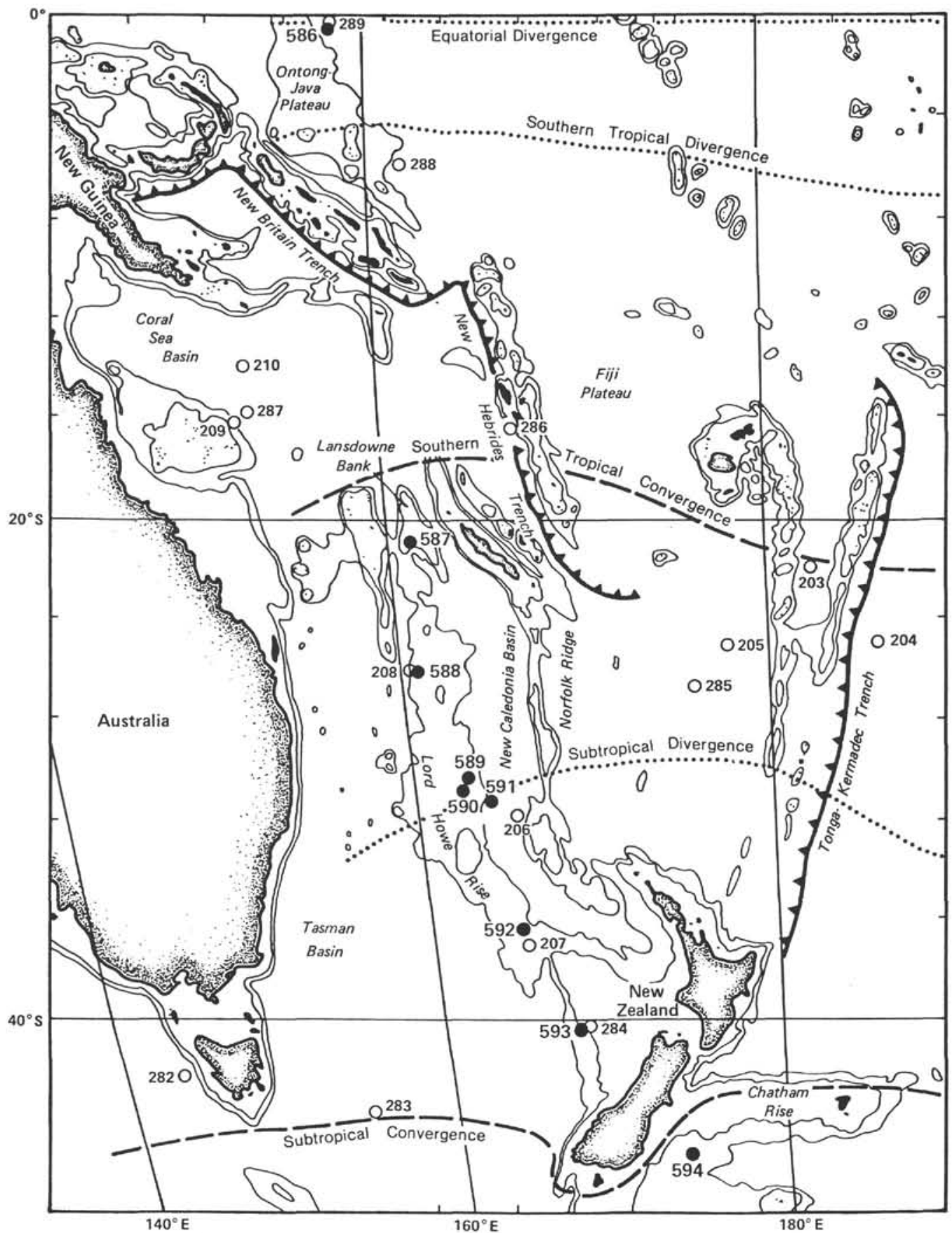

Figure 1. Location of sites drilled during Leg 90 (solid circles) and other DSDP drill sites (open circles) in the southwest Pacific.

nary a Mesocena quadrangula Horizon. It should be noted that no material was available for a short interval between the Naviculopsis iberica and the C. triacantha Zone; therefore, no zonal assignment is given for this interval. Only the datum levels of some Naviculopsis species extrapolated from other regions are indicated. The zonation used is otherwise representative for the low and middle latitudes in many regions of the oceans, as is demonstrated in the remarks following the identification of zones.

\section{Naviculopsis iberica Zone}

Definition. Interval from the first occurrence of $\mathrm{Na}$ viculopsis iberica to the last occurrence of $N$. navicula (new zone). Upper Oligocene to lower Miocene.

Occurrence. Present at Site 206, but not cored at Sites 591 and 594.

Remarks. The zone reflects a special development of late Oligocene to early Miocene silicoflagellate assemblages in the southern Pacific. In other regions the nom- 


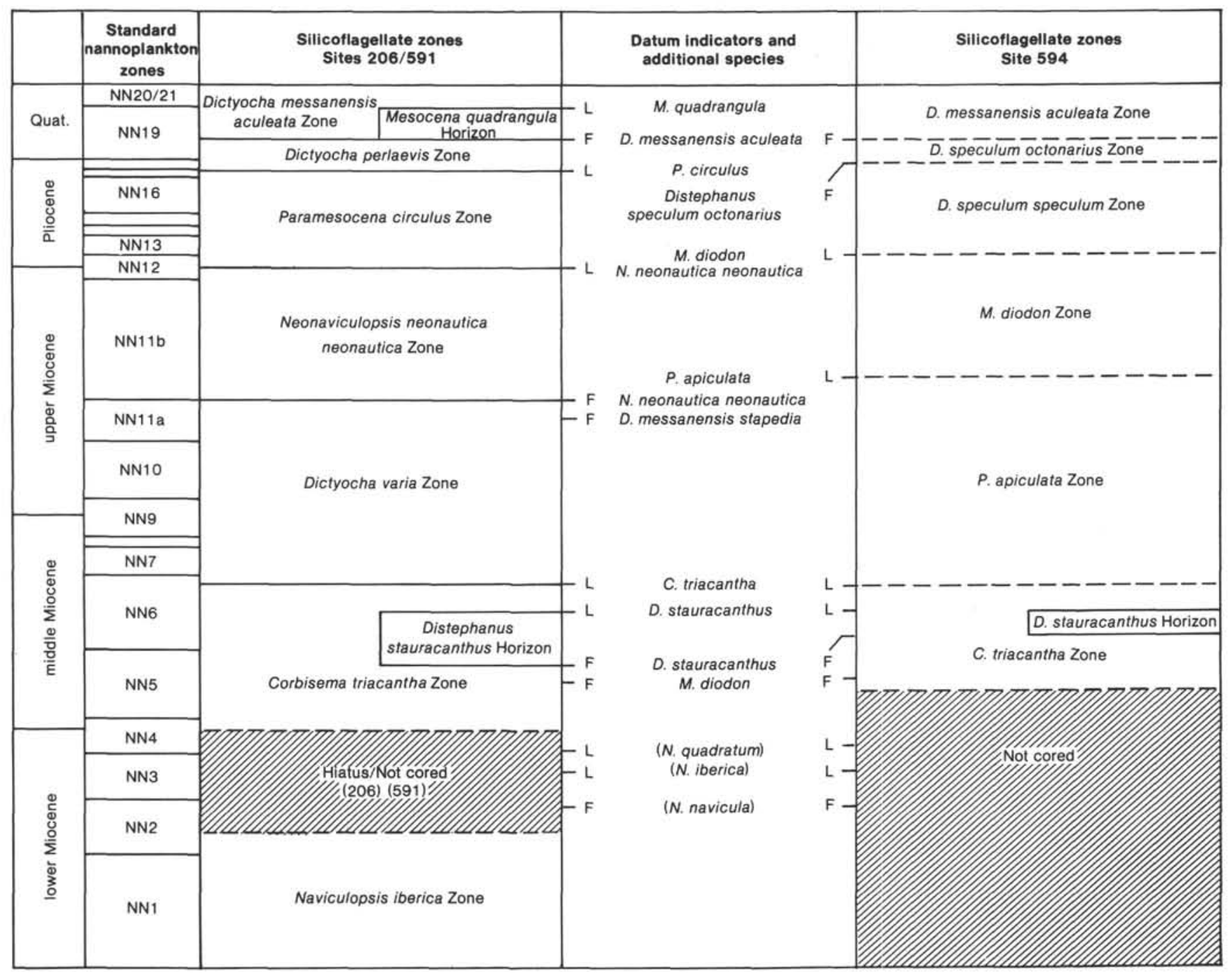

Figure 2. Silicoflagellate zones used at Sites 206/591 and Site 594, first (F) and last (L) occurrences of important silicoflagellate species, and correlation to standard nannoplankton zones. Parentheses indicate locations of datum levels within hiatus or uncored sections.

inate species may be associated with $N$. lata (Martini and Müller, 1976: Norwegian Sea, DSDP Site 338) indicating that the $N$. iberica Zone corresponds, more or less, to the $N$. lata Zone.

\section{Corbisema triacantha Zone}

Definition. Interval from the last occurrence of $\mathrm{Na}$ viculopsis species to the last occurrence of Corbisema triacantha (Martini, 1971a, 1972; base modified). Lower Miocene to middle Miocene.

Occurrence. Found at Site 591, Cores 591B-13 to 591B-21, and at Site 594, Cores 594A-12 to 594A-20 and Cores 594-46 to 594-53. Present also at Site 206.

Assemblage. At Site 591 Corbisema triacantha, Dictyocha fibula, and D. varia are common to abundant, and in the upper part, distinguished as Distephanus stauracanthus Horizon, some other species are also. Dictyocha fibula asymmetrica, D. medusa, Distephanus crux crux, and $D$. speculum giganteus are rare to few. The whole interval is characterized by the high number of
Cannopilus species and the presence of Macrora stella, a synuracean species.

In contrast to Site 591, most of the species cited are sparse at Site 594 . Only Corbisema triacantha and Distephanus crux crux are more or less consistently distributed throughout the zone. Most characteristic is the occurrence of Cannopilus depressus. Macrora stella is generally missing.

Remarks. The Corbisema triacantha Zone is rather uniformly developed in many regions. It was reported from low- and mid-latitude sites in the North Pacific (Experimental Mohole [EM] site, DSDP Sites 173, 469, 470, 472), central Pacific (DSDP Sites 65, 66, 71, 158, 495), South Pacific (DSDP Site 206), and North Atlantic (DSDP Sites 338, 369, 370, 391, 415, 416).

In higher latitudes identification of the zone may be difficult because $C$. triacantha specimens are fewer. But under these conditions, Cannopilus depressus may be used as a nearly time-equivalent indicator. High-latitude records with Corbisema triacantha scarcely present are 
known from the North Pacific (Sites 183, 433), the North Atlantic (Sites 407, 408), and the Antarctic (Sites 266, 323).

\section{Distephanus stauracanthus Horizon}

Definition. Interval in the upper Corbisema triacantha Zone characterized by the first and last appearance of Distephanus stauracanthus (Martini, 1972). Middle Miocene.

Occurrence. Found at Site 591, Cores 591B-15 to 591B-17, and at Site 594, Core 594A-12. Present also at Site 206.

Assemblage. At Site 591 Corbisema triacantha, Dictyocha extensa, D. varia, Distephanus crux crux, and D. stauracanthus are common to abundant.

Remarks. The horizon occupies an interval within the upper Corbisema triacantha Zone. It is distinguished by the rather short life-span of Distephanus stauracanthus (syn. D. octacanthus). Along with the Corbisema triacantha Zone, the horizon was reported from some lowand mid-latitude sections, mainly of the central and North Pacific. Clear indications exist, either as zone or by the nominate species, for the North Pacific (EM Site, DSDP Sites 173, 470, 472), central Pacific (Sites 66, 71), South Pacific (Site 206), and North Atlantic (Site 408).

\section{Dictyocha varia Zone}

Definition. Interval from the last occurrence of Corbisema triacantha to the first occurrence of Neonaviculopsis neonautica neonautica (new zone). Middle Miocene to upper Miocene.

Occurrence. Found at Site 591, Cores 591B-2 to 591B12 and Cores 591-28 to 591-31, and partially present also at Site 206.

Assemblage. At Site 591 Dictyocha fibula, D. varia, and Distephanus speculum speculum are common to abundant; Dictyocha extensa and D. medusa are rare to few. Dictyocha messanensis aspinosa changes in the upper part of the interval to $D$. messanensis stapedia. Distephanus crux hannai, consistently distributed in the lower part, disappears toward the end of the zone. Distephanus polyactis crassus and Paramesocena apiculata are consistently present only in the lower part.

Remarks. The Dictyocha varia Zone describes an intermediate interval between the datum levels of two other species. It may be present in low- and mid-latitude subdivisions of some authors though other species names are cited (possibly as part of $D$. rhombica, D. aspera, D. pulchella). Setting aside the terminology, this zone probably occurs in sections of the North Pacific (DSDP Sites 469, 470, 472), central Pacific (Sites 65, 66, 158, $315,495)$ and South Pacific (Site 206).

\section{Neonaviculopsis neonautica neonautica Zone}

Definition. Interval from the first to the last occurrence of Neonaviculopsis neonautica neonautica (in Bukry, 1981, as Dictyocha neonautica Subzone of his D. fibula Zone). Upper Miocene to lower Pliocene.

Occurrence. Found at Site 591, Cores 22 to 27.

Assemblage. Dictyocha fibula, D. messanensis stapedia, and Distephanus speculum speculum are common to abundant. Less common are Dictyocha extensa, D. varia, and also $N$. neonautica neonautica.

Remarks. The zone is distinguished by a species which is identical in its skeletal structure to Naviculopsis but generates first in the late Miocene, a long time after the extinction level of true Naviculopsis species in the early Miocene. Neonaviculopsis neonautica was cited or figured some years ago, but generally under other names (Bukry and Foster, 1973: Naviculopsis navicula; Martini, 1976: Dictyocha cf. ausonia; Ling, 1977: Naviculopsis iberica). These citations indicate the relatively wide distribution and usefulness of the zone.

The zone has been reported, or indicated by the species cited above, from sections in the North Pacific (DSDP Sites 469, 471), central Pacific (Sites 158, 315, $495,503,504)$, and now also from the South Pacific (Site 591).

\section{Paramesocena circulus Zone}

Definition. Interval from the last occurrence of $\mathrm{NeO}$ naviculopsis neonautica neonautica to the last occurrence of Paramesocena circulus (new zone). Lower Pliocene to upper Pliocene.

Occurrence. Found at Site 591, Cores 13 to 21 , and also present at Site 206.

Assemblage. At Site 591 Dictyocha fibula, D. messanensis stapedia, and Distephanus speculum speculum are common to abundant, as are also, in different parts of this zone, Dictyocha varia, Mesocena quadrangula, and Paramesocena circulus. Few to common are $D$. extensa, D. perlaevis, and Distephanus crux bispinosus, the last being very characteristic.

Remarks. The zone is defined by the disappearance of $N$. neonautica neonautica at its base and the disappearance of $P$. circulus, or other evolved Paramesocena species, at the top. In this sense the zone does not correspond to the Mesocena/Paradictyocha circulus Zone of other authors, which circumscribes a late Miocene interval in higher latitudes. The late Miocene $M$. circulus Zone needs some further study because it may be related to Paramesocena apiculata, a quite similar species.

Although no Paramesocena circulus Zone has yet been used for the Pliocene, it may be recognized by its nominate species, mentioned in various publications. Paramesocena circulus has been reported from Pliocene sections in the North Pacific (DSDP Site 310), central Pacific (Sites 321, 425, 504), South Pacific (Sites 206, 278), North Atlantic (Site 410), and South Atlantic (Site 362).

\section{Dictyocha perlaevis Zone}

Definition. Interval from the last occurrence of Paramesocena circulus to the first occurrence of Dictyocha messanensis aculeata (Dumitrică, 1973b; base redefined). Upper Pliocene to lower Quaternary.

Occurrence. Present at Site 206, but not found at Sites 591 (barren interval) and 594 (not present).

Remarks. The Dictyocha perlaevis Zone describes an intermediate interval between the datum levels of two other species. Because of its short duration it may sometimes be difficult to distinguish, but usually it may be recognized by the presence of the nominate species be- 
low the occurrence of $D$. messanensis aculeata or the acme of Mesocena quadrangula.

The zone can be traced over large areas. It was reported, or indicated by its nominate species, from lowand mid-latitude sites in the North, central and South Pacific and the North and South Atlantic.

\section{Mesocena quadrangula Horizon}

Definition. Interval near or at the base of the Dictyocha messanensis aculeata Zone characterized by the acme of Mesocena quadrangula, which is limited by the disappearance of the nominate species (Martini, 1971a; base and top redefined by Bukry, 1979b). lower Pleistocene.

Occurrence. Present at Site 206, but not found at Sites 591 (barren interval) and 594 (not present).

Remarks. The horizon was originally defined from the first to the last occurrence of Mesocena quadrangu$l a$, but later it was restricted to the conspicuous acme interval of the species because of its indistinct first appearance. In some earlier publications the species is also related to $M$. elliptica (Ling, 1970; Dumitrică, 1973a; and others). The horizon was reported or indicated by its nominate species from many low- and mid-latitude sections in the North, central, and South Pacific and also from a few sites in the North and South Atlantic.

\section{Dictyocha messanensis aculeata Zone}

Definition. Interval above the first occurrence of Dictyocha messanensis aculeata (introduced by Ling, 1972, as $D$. fibula var. aculeata assemblage; defined as $D$. aculeata Zone by Dumitrică, 1973b; Bukry and Foster, 1973). Lower Pleistocene to Recent.

Occurrence. Not found at Site 591 (barren interval), but present at Site 206 and Site 594, Cores 594-6 to 59411.

Assemblage. At Site 594 only Distephanus speculum speculum is consistently present, whereas Dictyocha messanensis aculeata occurs scattered and in low numbers.

Remarks. The zone is characterized by the multispined D. messanensis aculeata, which first appears in the early Pleistocene, corresponding to the beginning of the Mesocena quadrangula acme or shortly after that event. In some earlier publications this species was also referred to as D. epiodon (Bukry and Foster, 1973; and others) or noted as D. mandrai (Ling, 1977).

At Site 206 D. messanensis aculeata continues the warm to temperate species succession known from many sites at low and mid latitudes. But its presence at Site 594 does not reflect the general cooling trend from the middle/late Miocene to the early Pleistocene. The surprising appearance of $D$. messanensis aculeata at these latitudes may be normal or it might indicate a warming phase, as presumed for the same interval at Site 278 (Perch-Nielsen, 1975).

The Dictyocha messanensis aculeata Zone has been reported or is indicated by its nominate species from many low and mid-latitude sites in the North Pacific (TT sites in Ling, 1970; DSDP Sites 310, 466), central Pacific (Sites 84, 157, 315, 316, 321, 425, 427, 495, 504) South Pacific (Site 206), the North Atlantic (Sites 334,
397, 410, 412), Mediterranean Sea (Sites 127, 128), and South Atlantic (Site 358). However, it is documented also from some Pleistocene to Holocene higher-latitude sections in the North Pacific (TT sites of Ling; many sites described by Poelchau, 1976), South Pacific (Sites 278, 281), and South Atlantic (Site 328). The nominate species is sometimes associated with Distephanus octangulatus in the North Pacific.

\section{Site 594}

In the middle Miocene to early Pleistocene sequence at Site 594 a different subdivision is used because of the stronger affinities of the sequence with cool-water conditions. Above the Corbisema triacantha Zone, the zonation includes the Paramesocena apiculata Zone, $\mathrm{Me}$ socena diodon Zone, Distephanus speculum speculum Zone, and the D. speculum octonarius Zone (Fig. 2). In the North Pacific this succession is terminated by the $D$. octangulatus Zone, but from other high-latitude regions no comparable subunit is known.

\section{Paramesocena apiculata Zone}

Definition. Interval from the last occurrence of Corbisema triacantha to the last occurrence of Paramesocena apiculata (introduced by Ling, 1973, as Mesocena circulus var. apiculata Zone; defined by Bukry, 1975, as M. circulus Subzone of his Distephanus speculum speculum Zone). Middle to upper Miocene.

Occurrence. Found at Site 594, Cores 24 to 45.

Assemblage. Paramesocena apiculata is the only species which occurs more or less consistently throughout this zone. In the upper part Dictyocha varia, Distephanus crux crux, and D. speculum speculum are also present.

Remarks. The zone is defined by an early Paramesocena species which still possesses two rows of spines. Its disappearance seems to be a wide-ranging event, although it is insufficiently documented at present. It may be presumed that the late Miocene $M . / P$. circulus Zone distinguished in some high-latitude zonations is based on Paramesocena apiculata. But further investigations are needed.

Only a few indications exist for the Paramesocena apiculata Zone or the nominate species (North Pacific, DSDP Sites 173, 183, 192, EM site). Most reports register a Paradictyocha circulus or Mesocena circulus Zone in the middle to late Miocene interval: South Pacific (Site 278), Antarctic region (Sites 266, 274, 323), South Atlantic (Sites 328, 329, 358, 513), and North Atlantic (Sites 338,348 ). But these reports may be taken as indications of the Paramesocena apiculata Zone, because the figured specimens often belong to $P$. apiculata.

\section{Mesocena diodon Zone}

Definition. Interval from the last occurrence of Paramesocena apiculata to the last occurrence of Mesocena diodon (introduced by Perch-Nielsen, 1975, as $M$. diodon Subzone of her Paradictyocha dumitricae Zone; base modified). Upper Miocene to lower Pliocene.

Occurrence. Found at Site 594, Cores 594-21 to 59423. 
Assemblage. Rare to few but consistently present are Distephanus speculum speculum and Mesocena diodon.

Remarks. The lower boundary of the zone may be difficult to place in some sections but the upper boundary seems to be a wide-ranging and distinct datum level. The zone was reported, or indicated by its nominate species, from the North Pacific (DSDP Sites 173, 183, 192), South Pacific (Site 278), Antarctic region (Site 266), North Atlantic (Sites 348, 407), and South Atlantic (Site 513).

\section{Distephanus speculum speculum Zone}

Definition. Interval from the last occurrence of $\mathrm{Me}$ socena diodon to the first occurrence of Distephanus speculum speculum f. octonarius (Bukry, 1973; top redefined by Bukry, 1975; base modified). Lower to upper Pliocene. 20.

Occurrence. Found at Site 594, Cores 594-14 to 594-

Assemblage. Distephanus speculum speculum with its hexagonal form is the only consistent species. Dictyocha messanensis messanensis appears sporadically.

Remarks. The Distephanus speculum speculum Zone describes an intermediate interval between the datum levels of two other species. The zone is characterized by the high number of specimens belonging to $D$. speculum and by the low species diversity. The zone was reported, or is indicated by the species assemblage, from many sites in the North Pacific (DSDP Sites 173, 183, 185, 186), South Pacific (Site 278), Antarctic region (Sites 266, 269, 274), North Atlantic (Sites 348, 407), and South Atlantic (Site 328).

\section{Distephanus speculum octonarius Zone}

Definition. Interval from the first occurrence of $\mathrm{Di}$ stephanus speculum speculum $\mathrm{f}$. octonarius to the first occurrence of $D$. octangulatus (Ling, 1973; base redefined by Bukry, 1975). Lower Pleistocene.

Occurrence. Found at Site 594, Cores 594-12 to 59413.

Assemblage. Numerous forms of Distephanus speculum speculum including f. octonarius are present.

Remarks. The base of the zone is defined by the octogonal variants of Distephanus speculum, which are treat- ed here as forms of the subspecies $D$. speculum speculum, because no precise and representative data on the true nature of the group are available. Statistical investigations might show that the octonarius forms represent a subspecies Distephanus speculum octonarius, which is characterized by a series of multispined morphes. But for practical stratigraphy such taxonomic problems are not considered here, and the zonal name is abbreviated to $D$. speculum octonarius Zone. Regarding taxonomy, it should be noted also that in some publications the species is called D. polyactis (Bukry, 1973; Busen and Wise, 1977; and others).

The top of the zone is defined by the first appearance of Distephanus octangulatus, which is known at present only from the North Pacific. Further investigations may show if this species can be used also for late Quaternary stratigraphy in other high-latitude regions. For Site 594 this question is irrelevant, because the succession is continued by Dictyocha messanensis aculeata, which is a good zonal indicator in low and mid latitudes (see also remarks for $D$. messanensis aculeata Zone). The Distephanus speculum octonarius Zone is reported, or indicated by its nominate species, from the North Pacific (DSDP Sites 173, 183, 185, 186, 190, 192), South Pacific (Site 278), Antarctic region (Sites 266, 269, 274), North Atlantic (Site 407), and South Atlantic (Sites 328, 513). To evaluate the distribution or presence of certain species the following papers, besides those already cited, were consulted: Bukry, 1976b, 1977, 1979a, 1980a, 1980b, 1981a, 1982a; Fuji and Bachmann, 1970; Hajós, 1976; Haq and Riley, 1976; Ling, 1975, 1980; Martini, 1979; Müller, 1981; Perch-Nielsen, 1977; Shaw and Ciesielski, 1983.

\section{SITE SUMMARIES}

\section{Site $588\left(26^{\circ} 06.70^{\prime} \mathrm{S} ; 1^{\circ} 1^{\circ} 13.6^{\prime} \mathrm{E}\right.$; water depth $\left.1533 \mathrm{~m}\right)$}

At Hole $588 \mathrm{C}$, on the western part of Lord Howe Rise, Paleogene sediments containing silicoflagellates were encountered in Core 19, and are associated with diatoms, ebridians, radiolarians, rare sponge spicules, and calcareous nannoplankton. The silicoflagellate assemblage (Table 1) is dominated by Naviculopsis foliacea and Corbisema apiculata, and because $C$. bimucronata is also pres-

Table 1. Distribution of silicoflagellates in selected samples from Hole 588C, and indication of silicoflagellate and standard nannoplankton zones.

\begin{tabular}{|c|c|c|c|c|c|c|c|c|c|c|c|c|c|c|c|c|c|c|}
\hline Series & $\begin{array}{l}\text { Nanno- } \\
\text { plankton } \\
\text { zone }\end{array}$ & $\begin{array}{c}\text { Core-Section } \\
\text { (interval in cm) }\end{array}$ & 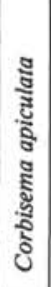 & 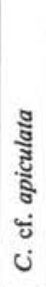 & 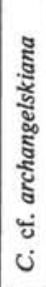 & 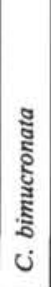 & 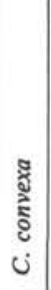 & जू & 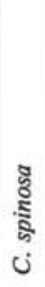 & 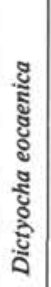 & 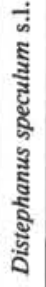 & 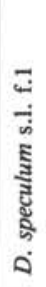 & 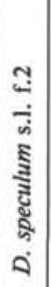 & 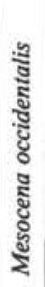 & 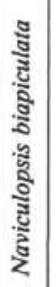 & 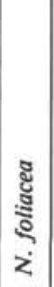 & 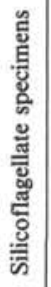 & $\begin{array}{l}\text { Silicoflagellate } \\
\text { zone }\end{array}$ \\
\hline $\begin{array}{l}\text { middle } \\
\text { Eocene }\end{array}$ & $\begin{array}{l}\text { NP15/ } \\
\text { NP16 }\end{array}$ & $\begin{array}{l}19-1,10-12 \\
19-1,35-37 \\
19-1,55-57 \\
19, \mathrm{CC}\end{array}$ & $\begin{array}{l}1 \\
1 \\
1\end{array}$ & $\begin{array}{l}2 \\
2 \\
2 \\
3\end{array}$ & $\begin{array}{l}1 \\
1\end{array}$ & $\begin{array}{l}1 \\
1\end{array}$ & $\begin{array}{l}1 \\
2 \\
1 \\
2\end{array}$ & 1 & 1 & $\begin{array}{l}1 \\
2 \\
1 \\
2\end{array}$ & 1 & $\begin{array}{l}1 \\
1\end{array}$ & $\begin{array}{l}1 \\
1 \\
1\end{array}$ & $\begin{array}{l}1 \\
1 \\
1 \\
1\end{array}$ & $\begin{array}{l}1 \\
2 \\
1 \\
1\end{array}$ & $\begin{array}{l}2 \\
2 \\
3 \\
2\end{array}$ & $\begin{array}{l}10 \\
16 \\
18 \\
21\end{array}$ & $\begin{array}{l}\text { Naviculopsis } \\
\text { foliacea } \\
\text { Zone }\end{array}$ \\
\hline
\end{tabular}

Note: Numbers indicate frequency. $1=1$ specimen, $2=2$ to 5 specimens, $3=6$ to 15 specimens, $4=16$ to 50 specimens, $5=>50$ specimens, counted on a 120 -mm traverse across the slides. 
ent the assemblage can be placed in the Middle Eocene Naviculopsis foliacea Zone (see Martini and Müller, 1976). A similar assemblage, although without $C$. bimucronata and slightly older, was found in Samples 208-27,CC and 208-28,CC, which were inspected for comparison from the nearby Site 208. For details on the silicoflagellates of this site see Dumitrică (1973b).

Associated calcareous nannoplankton indicate a middle Eocene age (Zone NP15/NP16), probably the middle part of Zone NP15 judging by a single specimen of Chiasmolithus gigas (Bramlette and Sullivan) in Sample $588 \mathrm{C}-19-1,10-12 \mathrm{~cm}$. This is in good agreement with the correlations indicated in Martini and Müller (1976, fig. 3).

\section{Site $591\left(31^{\circ} 35.0^{\prime} \mathrm{S} ; \mathbf{1 6 4}^{\circ} 26.92\right.$ ' E; water depth $2131 \mathrm{~m})$}

Site 591 is situated on the eastern part of Lord Howe Rise. Sediments recovered at this site consist mostly of foraminifer-bearing nannofossil ooze with low amounts of biosiliceous components, including diatoms, silicoflagellates, radiolarians, ebridians, actiniscidians, sponge spicules, and phytoliths. The investigated sequence, combined from Holes 591A, 591, and 591B, cover the middle Miocene to early Pleistocene interval. However, samples from above the lower Pliocene (591-11,CC and higher) are generally barren of silicoflagellates. The distribution of silicoflagellate taxa in the sequence and the correlations to calcareous nannoplankton zones (Martini, 1971b) are shown in Table 2.

The interval between Samples 591-13,CC and 591$21, \mathrm{CC}$ is placed in the lower Pliocene Paramesocena circulus Zone, with the nominate species common in several samples. Abundant or common are Dictyocha messanensis stapedia f. aspinosa, Distephanus speculum speculum $\mathrm{f}$. speculum and $D$. crux bispinosus f. bispinosus. Samples 591-22, CC to 591-27, CC belong to the $\mathrm{Ne}$ onaviculopsis neonautica neonautica Zone, based on the occurrence of the nominate species. Other taxa present include Dictyocha messanensis stapedia f. stapedia, D. varia, and Distephanus speculum speculum f. speculum. This zone straddles the Miocene/Pliocene boundary, as is indicated by the associated calcareous nannoplankton. The interval between Samples 591-28,CC and 591B$12, \mathrm{CC}$ is placed in the upper middle to upper Miocene Dictyocha varia Zone. The assemblages are dominated by Dictyocha fibula fibula and D. varia, and in the higher parts also by Distephanus speculum speculum $\mathrm{f}$. speculum. Relatively common in this zone are Dictyocha medusa, Distephanus crux hannai, $D$. polyactis crassus, and Paramesocena apiculata. In the lowest part of the Dictyocha varia Zone silicoflagellates are rare and rather insignificant. A barren interval follows, including Samples 591B-13,CC and 591B-14,CC. In Sample 591B$15, \mathrm{CC}$ Corbisema triacantha, which is found down to Sample 591B-21,CC, last occurs. Accordingly, this interval belongs in the Corbisema triacantha Zone. Also Macrora stella was noted in all samples containing silicoflagellates in this interval. In Samples 591B-15,CC to 591B-17,CC, Distephanus stauracanthus occurs. This level is shown as the Distephanus stauracanthus Horizon in Table 2; it belongs to the middle Miocene and can be correlated to the uppermost part of standard nannoplankton Zone NN5 (Sphenolithus heteromorphus Zone) and the lower part of Zone NN6 (Discoaster exilis Zone). The lowest Samples 591B-22,CC to 591B-24,CC are again barren of silicoflagellates.

Site 591 is close to Site 206, from which silicoflagellates were described by Dumitrică (1973b) for the interval from the late Oligocene to the Pleistocene. Important species, correlation to standard nannoplankton zones, and placement in silicoflagellate zones for both sites are shown in Figure 3. In Hole 206 a hiatus between the upper Miocene and Pliocene (206-20,CC and 206-21,CC) has already been noted by Dumitrică (1973b, fig. 1). The hiatus includes the upper part of nannoplankton Zone NN10 (Discoaster calcaris Zone) to the lower part of Zone NN12 (Ceratolithus tricorniculatus Zone), or part of the Dictyocha varia Zone and probably the complete Neonaviculopsis neonautica neonautica Zone in the silicoflagellate zonation. Another hiatus can be noted between Samples 206-33, CC and 206-34,CC, with the upper lower Miocene and lower middle Miocene (Zones NN2, part to NN5, part) missing. This hiatus, if present at Site 591, is smaller, because the lowest Sample 591B$24, C C$ has already reached a level which is tentatively placed in the uppermost nannoplankton Zone NN4 (Helicosphaera ampliaperta Zone). The late Miocene hiatus of Site 206 was not observed at Site 591, where a complete sequence from the middle Miocene to the Recent was encountered.

\section{Site $594\left(45^{\circ} 31.41^{\prime} \mathrm{S} ; 1^{\circ} 4^{\circ} 56.88^{\prime} \mathrm{E}\right.$; water depth $1204 \mathrm{~m}$ )}

Holes 594 and 594A are located at the southern margin of the Chatham Rise, east of the South Island of New Zealand. The predominantly calcareous sediments contain as minor components diatoms, silicoflagellates, radiolarians, sponge spicules, and also some ebridians and actiniscidians throughout the Miocene to Quaternary sequence. A combination of core-catcher samples from Hole $594(594-1, \mathrm{CC}$ to $594-53, \mathrm{CC})$ for most of the sequence and from Hole 594A (594A-12, CC to 594A$25, C C)$ for the lowest part was used for detailed silicoflagellate investigation and correlation to calcareous nannoplankton zones (Table 3).

Severe reworking of silicoflagellates from older strata, especially from the Eocene and Oligocene, was noted throughout the sequence. Species obviously reworked are indicated by an asterisk beside the species name in Table 3. Some difficulties arise with species ranging into the Miocene, like Corbisema triacantha, which occurs, quite unusually, in the upper Miocene, lower Pliocene, and even in some Pleistocene samples. As they are in most cases associated with reworked Naviculopsis species, these occurrences are treated as erratics. Reworking was also noted in shipboard ebridian and diatom studies. Shorebased diatom studies (Ciesielski, this volume) even revealed several short hiatuses in the Pliocene and Pleistocene, which seem to occur just at calcareous nannoplankton zonal boundaries (between NN12/NN14 and NN15; NN15 and NN16/NN19A; NN16/NN19A and NN19B), but could not be detected in the silicoflagellate succession, probably because of low zonal resolution. In 


\section{S. LOCKER, E. MARTINI}

Table 2. Distribution of silicoflagellates in selected samples from Site 591, indication of silicoflagellate zones, and correlation to standard nannoplankton zones.

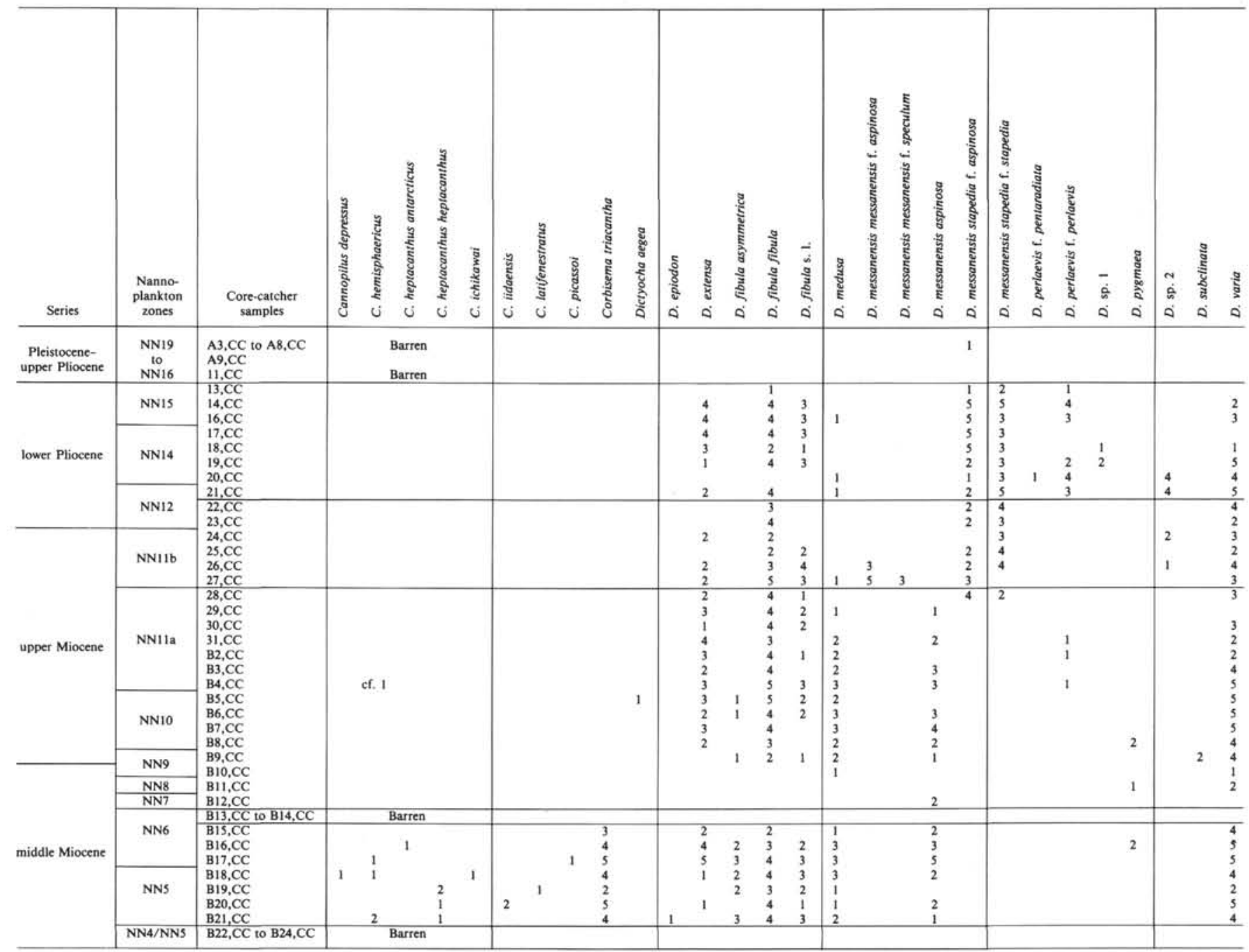

Note: Numbers indicate frequency (see Table 1). Species marked by an asterisk are reworked from the Paleogene.

view of these uncertainties, zonal boundaries for the silicoflagellates at Site 594 are tentative and are shown in dashed lines in Figure 2 and Table 3.

The uppermost samples from 594-1,CC to 594-5,CC, representing the late Quaternary, are barren of silicoflagellates. Samples 594-6,CC to 594-11,CC contain silicoflagellates in varying numbers, among these Distephanus speculum speculum and Dictyocha messanensis, each represented by several forms. Dictyocha messanensis aculeata has its first occurrence in Sample 594-11,CC, placing this interval in the middle Quaternary Dictyocha messanensis aculeata Zone. Samples 594-12,CC and 59413,CC belong to the Distephanus speculum octonarius Zone of early Pleistocene age, with the nominate taxon present in Sample 594-13,CC.

The assemblages in most of the Pliocene, including Samples 594-14,CC to 594-20,CC, are dominated by $\mathrm{Di}$ stephanus speculum speculum and are placed in the $D$. speculum speculum Zone. Also present in this interval are a few specimens of Dictyocha fibula and D. messanensis. A short interval (594-21,CC to 594-23,CC) around the Miocene/Pliocene boundary, where the last consistent occurrence of Mesocena diodon was noted, belongs to the Mesocena diodon Zone, which replaces the Neonaviculopsis neonautica neonautica Zone (Fig. 2) in these high southern latitudes. Below this interval Paramesocena apiculata is found consistently in most samples, together with $D$. varia, Distephanus crux crux, and $M$. diodon in the upper part. Accordingly Samples 594-24, CC down to 594-45, CC, just above what is considered the last autochthonous occurrence of Corbisema triacantha, are placed in the Paramesocena apiculata Zone of late middle to early late Miocene age. In the lower part of this interval silicoflagellates become rare. The Corbisema triacantha Zone below includes Samples 594-46, CC to 594A-20,CC. Other taxa present are Cannopilus depressus, D. crux crux, Dictyocha varia, $M$. diodon, and at level 594A-12,CC, Distephanus stauracanthus, which may be differentiated as the Distephanus stauracanthus Horizon, also found at Site 591 in the same position. The lowest part recovered in Hole 594A (Samples 594A-21,CC to 594A-25,CC), still belonging 
Table 2. (Continued).

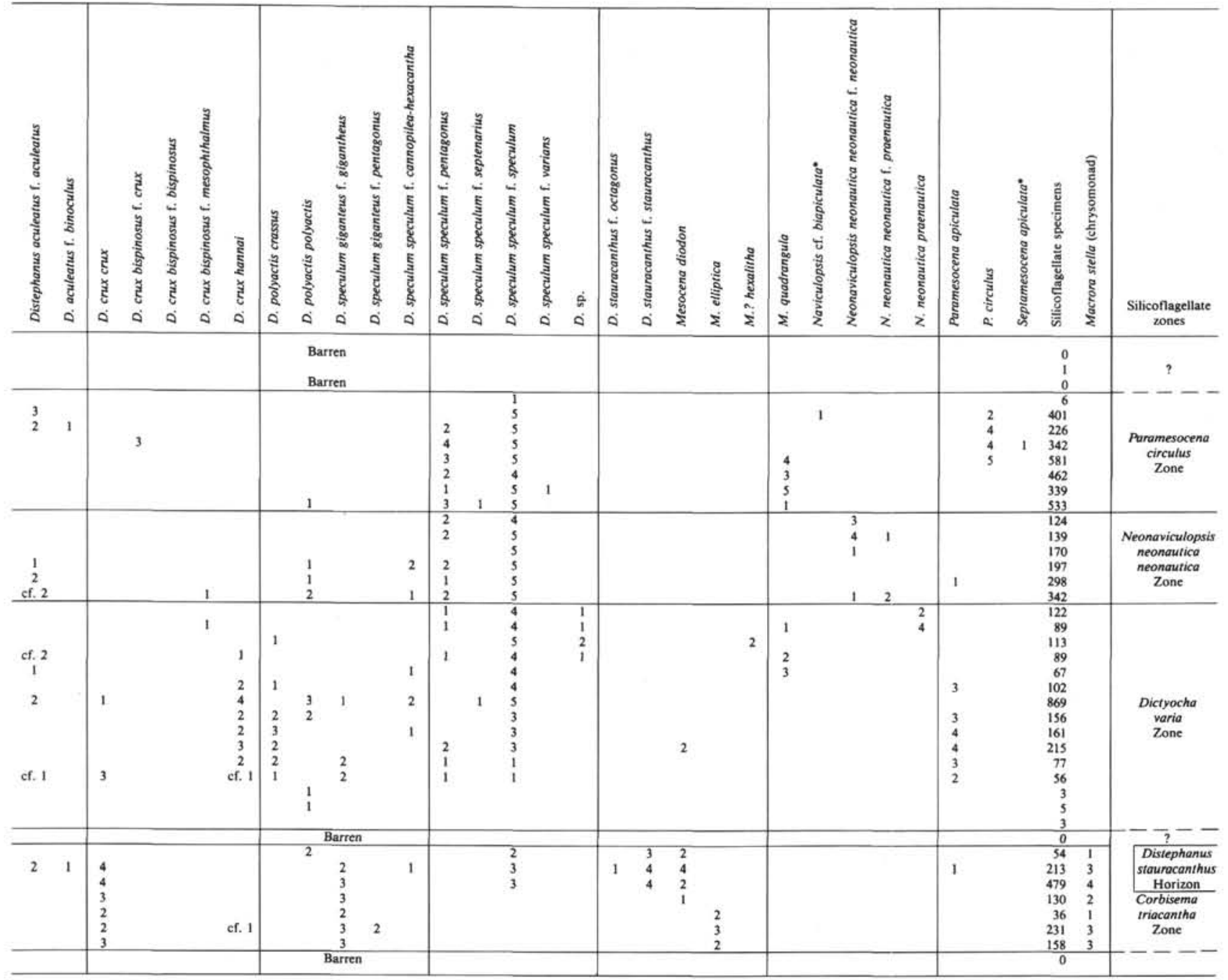

to calcareous nannoplankton Zone NN5 (Sphenolithus heteromorphus Zone), is barren of silicoflagellates.

All samples from Sites 591 and 594 can be correlated directly to standard nannoplankton zones (Martini, 1971b), which are indicated in Figures 2 and 3 as well as in Tables 1 to 3 . The best correlations are possible between silicoflagellate and nannoplankton zones at Site 591 and also at Site 206, whereas correlations at Site 594 are somewhat hampered by $\approx$ steady reworking of $\mathrm{Pa}$ leogene silicoflagellates into the Neogene to Quaternary sequence. A summary of correlations is given in Figure 2 , with coverage best in the middle Miocene to Quaternary interval at Sites 591 and 206 and less reliable at Site 594, as indicated by dashed lines in Figure 2.

\section{TAXONOMY}

\section{Stratigraphic Implications}

Taxonomy is a special field of research in neontology and paleontology that aims to establish taxa both of plant and animal organisms that are clearly defined and stable in nomenclature, and that are generally in accordance with biological and phylogenetic data. Some of the problems still present in silicoflagellate stratigraphy are influenced by taxonomic ideas, especially by the species concepts used and synonymies hitherto not noted. The species concept upon which the following discussions are based is explained in the next section.

The species concept employed to determine silicoflagellate taxa of specific or intraspecific rank may have great importance in applied stratigraphy. If the population polymorphism of skeletons and the resulting interspecific and intergeneric homeomorphisms (present especially in the genera Dictyocha, Distephanus, and Connopilus) are not taken into account, subdividing and correlating geological sections will be difficult. Particular skeletal morphes produced by one species during different periods of its geological life-span may lead, for instance, to restricted or diachronous zones if datums are based on its range. (See the application of Distephanus speculum f. pentagonus as a time indicator for a late Miocene zone in Ling, 1973, and for an Oligocene-Miocene zone in Bukry, 1974.) Homologous skeletal morphes appearing in different species of the same genus or analogous morphes occurring in some species of different genera may lead to stratigraphic misinterpretations if they are 
Site 591

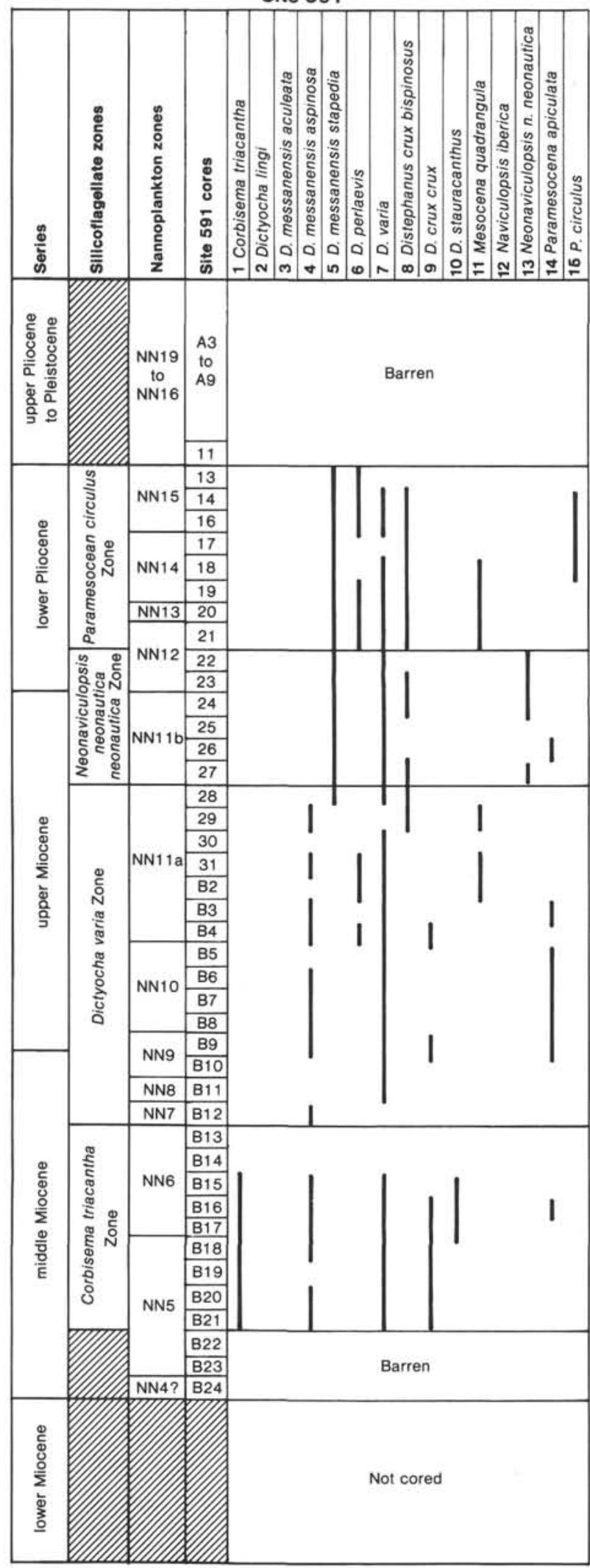

Site 206

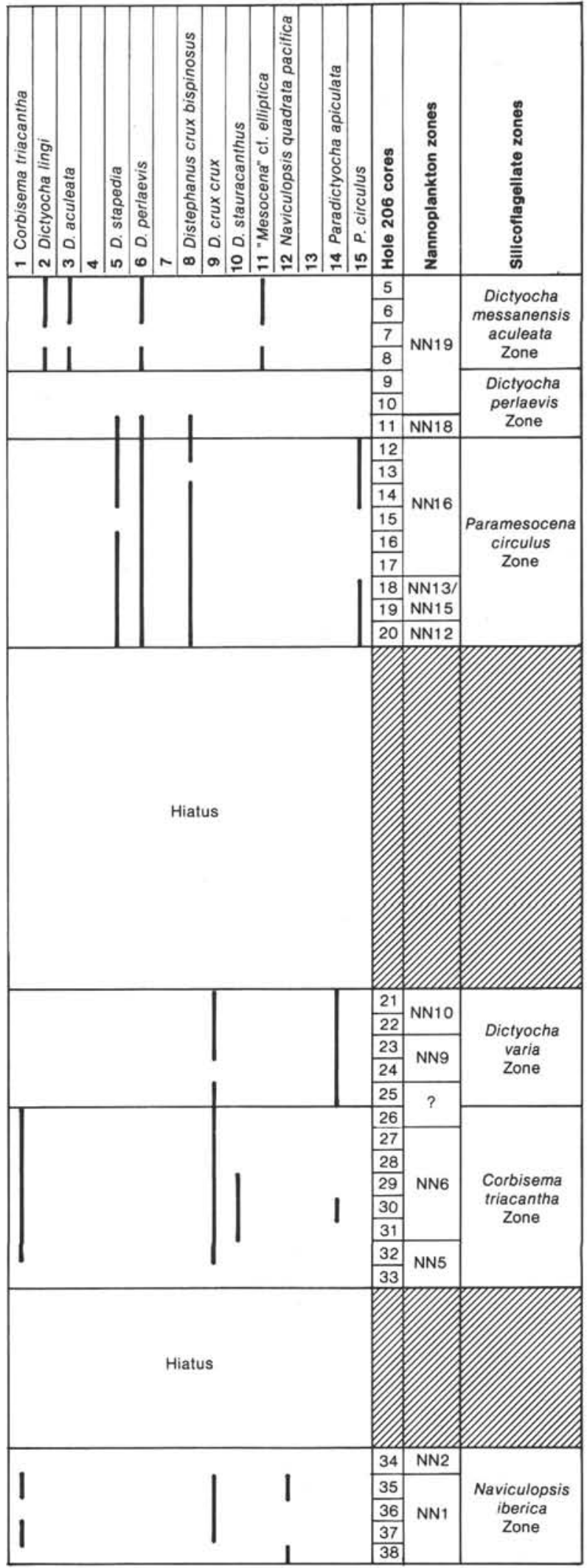

Figure 3. Distribution of important silicoflagellate taxa in core-catcher samples of Holes 591, 591B, and 206. Position of samples in the silicoflagellate and standard nannoplankton zonation and hiatuses are indicated. Standard nannoplankton zones in Hole 206 deduced from data shown in the Site 206 site chapter (Burns, Andrews, et al., 1973) and from Bukry (1973, fig. 2). Hole 591B cores indicated by B preceding core number. Corresponding species are marked by the same number. Site 591 species names, this chapter; Site 206 names, Dumitrică, 1973b. 
given the same name (see the distinction of homologous forms of Distephanus aculeatus and D. speculum and analogous forms in D. speculum and Cannopilus hemisphaericus, this paper).

The intraspecific polytypism expressed in interpopulation differences of skeletal habitus comprises another field of stratigraphic implications. The differentiation of some species into subspecies realized in time and/or space may provide good possibilities for detailed age determinations, but often such variations are not known or documented (see the subdivision of Distephanus crux into the three subspecies crux, bispinosus, and hannai, and their stratigraphic distribution, this paper).

In general, the polymorphism and polytypism of species reflect a wide but not irregular range of skeletal variation in silicoflagellates. For some years it has been known that intraspecific variation may be very great under special conditions (Frenguelli, 1935, 1938; Van Valkenburg and Norris, 1970; Bachmann, 1971) but that normally it is limited. Investigations have shown that taxonomic distinction within a group of similar forms may be possible on the basis of statistical and biological considerations (see the distinction between Mesocena elliptica, tetragonal forms of $M$. diodon, and $M$. quadrangula, this paper).

In some cases synonyms and homonyms can mask conformities between stratigraphic successions of species in different areas. Fundamental in this respect are all species names introduced by C. G. Ehrenberg in the nineteenth century. Some of them that still influence the application of the Neogene silicoflagellate zonation scheme will be noted here. In general, the following names may be correlated on the species level (whereas intraspecific differentiation may be entirely possible): Cannopilus sphaericus Gemeinhardt to $C$. depressus (Ehrenberg), Dictyocha ausonia Deflandre and D. aspera (Lemmermann) to D. fibula Ehrenberg, Distephanus boliviensis boliviensis (Frenguelli) to D. aculeatus (Ehrenberg), D. boliviensis major (Frenguelli) to $C$. heptacanthus (Ehrenberg), D. octacanthus (Desikachary and Maheshwari) to D. stauracanthus (Ehrenberg), and Naviculopsis rectangularis (Schulz) to N. quadratum (Ehrenberg). Beside these synonyms, some equivalences have been published that cannot be confirmed: Dictyocha epiodon Ehrenberg does not correspond to the Quaternary $D$. messanensis aculeata (Lemmermann), and Mesocena elliptica Ehrenberg is distinctly separated from $M$. quadrangula Haeckel, both in time and habitus. It is to be hoped that confusion about the stratigraphic ranges of species caused by synonyms will be soon overcome by fixing the correct names, that is, the oldest legitimate names.

Additionally, there are some difficulties that may arise from the use of homonyms in species names. In Neogene stratigraphy especially, a clear decision must be made between Dictyocha aculeata Ehrenberg (now changed to Distephanus aculeatus) and Dictyocha aculeata (Lemmermann) (ex D. fibula var. aculeata Lemmermann, here given as $D$. messanensis aculeata); between Mesocena apiculata (Schulz) (ex M. oamaruensis var. apiculata Schulz, now changed to Septamesocena apiculata), and $M$. apiculata (Lemmermann) (ex. $M$. circulus var. apiculata Lemmermann, here transferred to Paramesocena apiculata); between Naviculopsis ponticulus (Ehrenberg) (ex Dictyocha ponticulus Ehrenberg, really a taxon belonging to Naviculopsis) and $N$. ponticula Perch-Nielsen.

Last but not least must be mentioned the provincialism of various silicoflagellate species, a biological-taxonomic phenomenon which bears strong stratigraphic implications. As now known (Gemeinhardt, 1934; Mandra, 1969; Martini, 1971a; Ciesielski, 1975; Busen and Wise, 1977; Bukry, 1983), some silicoflagellate species are adapted predominantly to tropical-subtropical or warm-water conditions (many Dictyocha species) and other species mainly to nontropical or cool-water conditions (some Distephanus and Mesocena species). This large-scale mode of geographic distribution may produce considerable difficulties if low-latitude and high-latitude sections are compared. The picture may be modified, furthermore, by some intraspecific taxa which are adapted to special conditions of limited water masses (in Distephanus speculum and Mesocena diodon, for example). The patchwork geographic distribution occurring in some subspecies or varieties may also cause difficulties in stratigraphic investigations because these taxa may have different timeranges in separate areas.

\section{Species Concept}

Silicoflagellates are unicellular marine algae which produce a siliceous endoskeleton consisting of hollow rods. Because they are plants, the $I C B N$ rules must be applied to discriminate and define taxa. According to the rules, in addition to the species some intraspecific taxa may be included in a species concept.

The species concept used here is based on statistical investigations made to clarify the taxonomic position of the species introduced by C. G. Ehrenberg (Locker, unpublished data), and on published empirical data (selected citations below). The statistical investigations have shown that the difficulties still present in silicoflagellate taxonomy can be solved only if species are treated exclusively as biological entities (groups of individuals sometimes differing in habitus but generally linked by genetic processes) rather than typological entities (groups of individuals exhibiting only a similar habitus).

The concept introduced some years ago (Locker, 1974) and explained now in more detail is based on the axiom that silicoflagellates possess temporary phases of sexual reproduction. Such phases have not yet been demonstrated but may be deduced from the relatively high stability of fossil and recent species. The persistent homogeneity of silicoflagellate species, a homogeneity often threatened by strong and divergent variation, can only be understood if sexual processes are presumed.

If sexual processes do indeed exist in silicoflagellates, some of Mayr's (1967) criteria for determining taxa in bisexually reproducing animals can also be used in silicoflagellates, although they are unicellular plants. Thus in Table 4, in addition to the categories species and subspecies, which are covered by the zoological criteria of Mayr, the two intraspecific but solely botanical catego- 
Table 3. Distribution of silicoflagellates in selected samples from Site 594, indication of silicoflagellate zones, and correlation to standard nannoplankton zones.

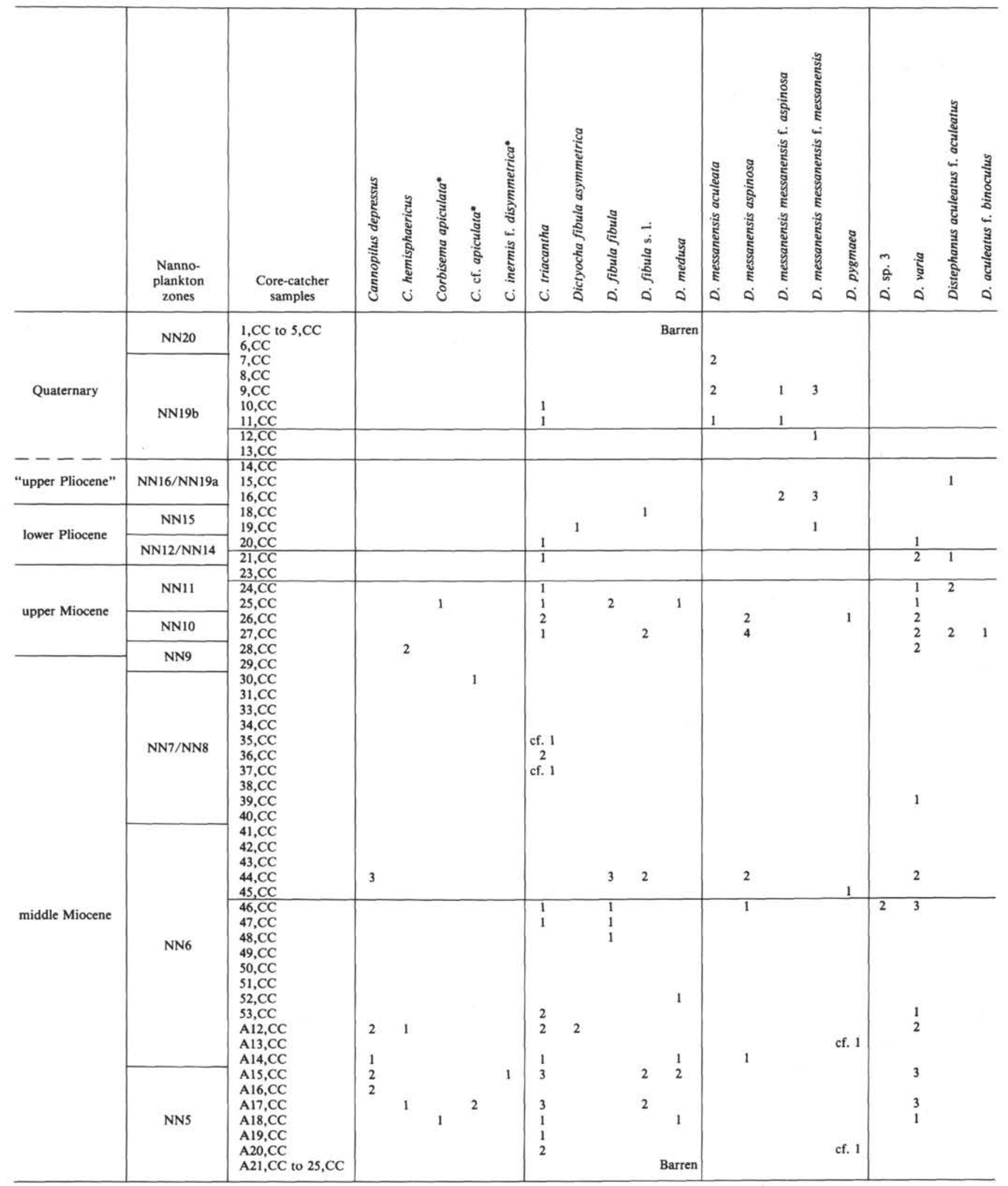

Note: Numbers indicate frequency (see Table 1). Species marked by an asterisk are reworked from the Paleogene. 
Table 3. (Continued).

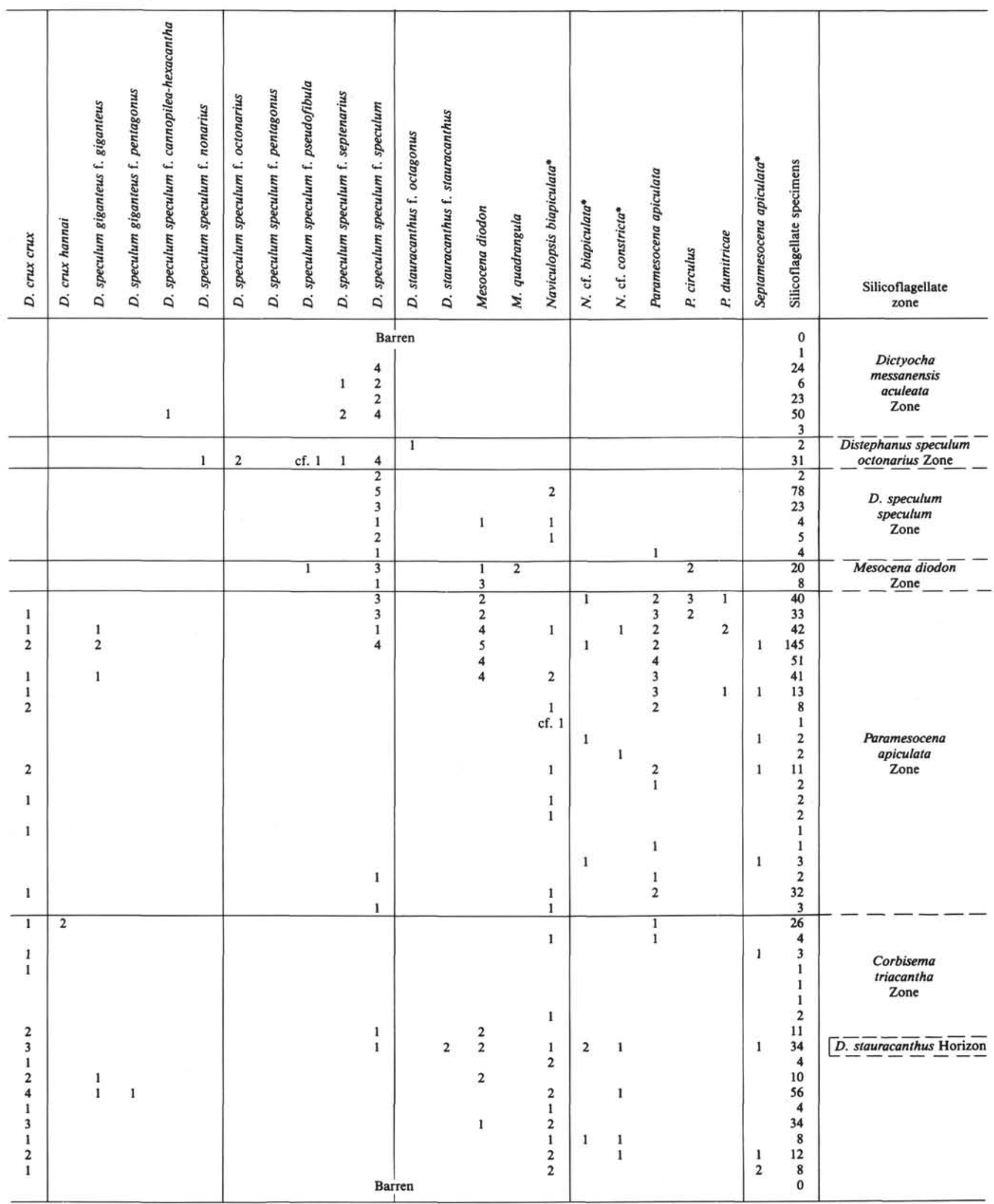


Table 4. Principles of a species concept: biological and typological characters for distinguishing silicoflagellate taxa.

Biological characters

Typological characters

Species (species)

Based on a unique population or various populations. Strongly separated genetically and commonly also in skeletal morphology from other species. Geographically and/or stratigraphically co-occurring with closely related species (allopatric or sympatric distribution).

\section{Subspecies (subspecies)}

Based on a single population or several populations. Slightly distinct genetically from other subspecies of the same species, but distinctly differentiated in skeletal morphology. Geographically and/or stratigraphically separated from other subspecies of the species (allopatric distribution).

\section{Variety (varietas)}

Based on a single population or several populations, often including clones. Presumably not genetically distinct or only slightly distinct from other varieties of the same species or subspecies, but differentiated in skeletal morphology (characters predominantly forced by ecology). Sometimes geographically and/or stratigraphically separated from other varieties of the species (allopatric or sympatric distribution).

\section{Form (forma)}

Based on a special group of individuals in a population, often including clones. Strongly separated genetically and in skeletal morphology from other forms of the same population. Generally cooccurring with other forms of the population (sympatric distribution).

\section{Species}

Comprises skeletons with special habitus. May be taxonomically fixed by features which vary continuously but sometimes also discontinuously. Examples:

${ }^{*}$ Dictyocha fibula-Dictyocha varia (distinguishing features continuously varying $=$ dimensions and proportions of the basal ring and apical bar).

*Cannopilus hemisphaericus-Cannopilus schulzii (features discontinuously varying $=$ number of radial spines).

\section{Subspecies}

Comprises skeletons which are distinctly different in habitus compared to other subspecies of the same species (habitual polytypism). May be taxonomically fixed by features which vary continuously but sometimes also discontinuously. Examples:

${ }^{*}$ Distephanus crux crux-Distephanus crux hannai (discriminating features varying continuously - dimensions and proportions of the basal and apical ring).

*Dictyocha messanensis stapedia-Dictyocha messanensis aspinosa (features varying discontinuously $=$ presence or absence of variants with an apical pike).

\section{Variety}

Comprises skeletons which are slightly different in habitus compared to other varieties of the same species or subspecies. May be taxonomically fixed by features which vary continuously.

\section{Form}

Comprises skeletons which are strongly different in habitus compared to other forms of the same population (habitual polymorphism). May be taxonomically fixed by features which vary discontinuously. Examples:

${ }^{*}$ Distephanus speculum speculum $\mathrm{f}$. speculum-Distephanus speculum speculum f. septenarius (number of radial spines).

In terms of genetics, these forms must be quoted as morphes. The concept of intrapopulation polymorphism agrees well with the empirical data received from recent populations of silicoflagellates and also with statistical evaluations of fossil populations (recent populations: Hovasse, 1932; Frenguelli, 1935, 1938; Van Valkenburg and Norris, 1970; fossil populations: Deflandre, 1950, 1952; Bachmann, 1970, 1971; Locker, unpublished data). Nevertheless, in some cases it may be difficult to apply the concept because similar morphes may be developed in different species of the same genus (homologous morphes). Making distinctions will be further complicated by populations containing, in addition to the normal variants, morphes which correspond in habitus to forms of other genera (analogous morphes). Morphes of the last type are known especially from the genera Corbisema (dictyochid forms), Dictyocha (mainly distephanoid and cannopiloid forms), and Distephanus (dictyochid and cannopiloid forms). Therefore, a taxonomy satisfactory on the specific and intraspecific level can only be established if all data-genetic, habitual, geographic, stratigraphic, and statistical-are considered.

Finally, variation patterns can be modified by polymorphisms in size which are caused, presumably, by ecological conditions. Populations with relatively small skel- 
etons occur as well as populations with larger skeletons. This mode of variation can be roughly registered empirically, but more exact statistical methods are desirable. In this chapter, variations expressed only in size are regarded as taxonomically insignificant; that is, no special names should be introduced.

The large number of variations possible in any given homogeneous group of silicoflagellate skeletons explains the difficulty in making completely satisfactory taxonomic evaluations. The species concept proposed here is intended to establish precise criteria for distinguishing intraspecific taxa, criteria that are biologically based and that may be reproduced in fossil populations.

\section{Remarks on Ehrenberg's Species}

As indicated earlier, the species names introduced by C. G. Ehrenberg (1795-1876) from 1838 to 1873 are fundamental in silicoflagellate taxonomy because they are the oldest citations. Most of the names were validated by Ehrenberg with a description but for many he provided no figure, and some were published only as nomina nuda. Therefore, Locker (1974) undertook a revision of types.

The revision of Ehrenberg's species was accomplished using the following general scheme: (1) selection of the type locality by means of the first description; (2) examination of the type series; and (3) fixing of a lectotype or corroboration of a holotype. Because this procedure was in accordance with the rules of nomenclature, the typifications must be accepted (ICBN, article 8.1; ICZN, article 24a). The only exception concerns the type of Dictyocha crux. Because of special circumstances in the Ehrenberg collection, the two species $D$. crux and $D$. mesophthalma were confused by use of the same type specimen. But in all other cases the types fixed in 1974 can be taken as a base for further taxonomic procedures, such as fusion of names used by Ehrenberg or establishing equivalences with names of later authors.

In this context we should mention a typical source of error. As indicated by Ehrenberg's original publications, many of the species names must be treated as substantives in apposition; that is, if such species are transferred to other genera, the Latin endings should not be altered (ICBN, articles 23.5, 24.2; ICZN, article $11 \mathrm{~g})$. Among others, the names circulus, heptacanthus, ornamentum, ponticulus, quadratum, speculum, and stauracanthus are affected by this rule.

\section{Systematic Descriptions}

In this chapter all autochthonous species are discussed (allochthonous species are marked with an asterisk in Tables 2 and 3). Without exception, genera and species are described in alphabetical order, according to the rules of the ICBN. Following the species concept explained above, intraspecific taxa, like subspecies and forms, are distinguished within some species. These taxa are generally indicated by a rank-denoting term (ICBN, article 24.1). But in other sections we have done so only in the case of forms, because for subspecies the third position in a name is indicative enough.

Referring to the species concept, homologous forms occurring in different subspecies of the same species are given the same name, because it may be assumed that equivalent forms within one species are produced by the same alleles or combinations of alleles. Only in nominate taxa were different homonymic combinations used, according to the rules of nomenclature (ICBN, article 26.1). For example, Distephanus speculum speculum f. speculum corresponds, in skeletal structure, exactly with $D$. speculum giganteus f. giganteus.

Below the species name only the most important synonyms are cited. In descriptive terminology we followed mainly Bukry (1976b), but some other terms were also used. The term "apical structure" was replaced by the more unwieldy "apical apparatus," because "structure" is treated here in its systemological sense as indicating relations between the elements of any given system.

\section{Class CHRYSOPHYCEAE Order SILICOFLAGELLATA Borgert, 1891 Genus CANNOPILUS Haeckel, 1887}

Type species. Cannopilus hemisphaericus (Ehrenberg, 1845) Haeckel, 1887 ex Dictyocha hemisphaerica Ehrenberg, 1845.

Typification. In Loeblich et al. (1968) it is suggested that the genus Cannopilus Haeckel, 1887, might belong in the synonymy of Halicalyptra Ehrenberg, 1854. But according to Locker (1974) the genus $\mathrm{Ha}$ licalyptra must be placed with the Radiolaria, and the two silicoflagellate species included by Ehrenberg himself must be transferred to Cannopilus.

In 1974, Locker noted that the selection of $H$. virginica Ehrenberg, 1854 , as type of the genus Halicalyptra (Campbell, 1954) was mistaken because the species name had been introduced with a genus in question (cited as Halicalyptra? virginica) - a designation prohibited by Article $67 \mathrm{~h}$ of the ICZN (exclusion of species inquirenda or species incertae sedis), and recommendation 7B or article 8.1 of the ICBN (nomination in accordance with the protologue). Locker, therefore, corrected the determination and appointed $H$. fimbriata Ehrenberg, 1854, as the type genus of Halicalyptra.

Description. Skeleton consisting of a basal ring and an apical apparatus. Basal ring polygonal or circular, with 5 to 12 radial spines or spines absent; usually with basal pikes, but sometimes pikes absent. Apical apparatus semiglobular or nearly globular, furnished with 2 or more apical windows, often bearing accessory pikes.

Remarks. All species of Cannopilus are provided with 2 or more apical windows. The fenestrate apical apparatus of Cannopilus generally represents a relatively high and late evolutionary stage in silicoflagellates which obviously arises from some late Oligocene Distephanus species. The normal variants of these Distephanus species are furnished with a simple apical ring but generalist forms with a fenestrate apparatus-so-called cannopiloid morphes-are produced. During a relatively short geological time-span these early cannopiloid variants were transformed by phylogenetic selection and stabilization processes into obligatory fenestrate species.

Usually the cannopiloid specimens of Distephanus and normal individuals of Cannopilus found in the same material may be distinguished by additional skeletal features, but in some cases only statistical or genetic methods may lead to sufficient taxonomic discrimination.

\section{Cannopilus depressus (Ehrenberg) Locker \\ (Plate 1, Fig. 1)}

1854 Halicalyptra depressa Ehrenberg, Mikrogeologie, plate 18, fig. 111.

1931 Cannopilus sphaericus Gemeinhardt, Ber. D. Bot. Ges., 49:105, plate 10 , figs. 3-4.

1974 Cannopilus depressus (Ehrenberg) in Locker, Eclog. Geol. Helv., 67:639, plate 4, fig. 3 (=lectotype).

Remarks. The specimens have a globular apical apparatus which is perforated by many large apical windows.

\section{Cannopilus hemisphaericus (Ehrenberg) Haeckel (Plate 1, Fig. 7)}

1845 Dictyocha hemisphaerica Ehrenberg, Ber. Akad. Wiss. Berlin, 1844:266-267.

1887 Cannopilus hemisphaericus (Ehrenberg) in Haeckel, Rep. Sci. Res. Voy. Challenger, 18:1569.

1974 Cannopilus hemisphaericus (Ehrenberg) in Locker, Eclog. Geol. Helv., 67:639, plate 4, fig. 1 (= lectotype), figs. 4, 5, 7, 8 (= other types).

Remarks. This species shows a basal ring with spines arranged in the plane of the ring. The semiglobular apical apparatus usually bears only a few apical windows. 


\section{Cannopilus heptacanthus (Ehrenberg) Locker}

Remarks. Cannopilus heptacanthus is characterized by a large basal ring armed with 7 or more radial spines. Basal pikes are usually not developed. The apical apparatus generally exhibits several windows. The subspecies may be distinguished by the width of the apical apparatus in relation to the basal ring and by the number of apical windows.

\section{Cannopilus heptacanthus ssp. antarcticus (Ciesielski) n. comb.} (Plate 1, Fig. 10)

1975 Cannopilus antarcticus Ciesielski, Init. Repts. DSDP, 28:654, plate 1, figs. 1-9.

Remarks. This large subspecies displays an apical apparatus which is divided into many small windows. The lateral windows are remarkably large.

\section{Cannopilus heptacanthus (Ehrenberg) ssp. heptacanthus}

$$
\text { (Plate 1, Fig. 9) }
$$

1841 Dictyocha heptacanthus Ehrenberg, Ber. Akad. Wiss. Berlin, 1840:208.

1854 Dictyocha heptacanthus Ehrenberg in Ehrenberg, Mikrogeologie, plate 19, fig. 39 .

1951 Dictyocha boliviensis var. major Frenguelli, Physis, 20:277, fig. $3 a-c$.

1974 Cannopilus heptacanthus (Ehrenberg) in Locker, Eclog. Geol. Helv., 67:639, plate 4, fig. 9 (=holotype).

Remarks. This large subspecies generally possesses 7 radial spines in the material investigated. The apical apparatus is furnished with a few large windows.

\section{Cannopilus ichikawai Bachmann}

(Plate 1, Figs. 2, 3)

1964 Cannopilus ichikawai Bachmann, Sci. Rep. Kanazawa Univ., 9: 110 , plate 6 , figs. $59-61$.

Remarks. This large globular species shows no radial spines but has long basal pikes which are oriented toward the center.

\section{Cannopilus iidaensis Bachmann}

(Plate 1, Figs. 5, 6)

1967 Cannopilus iidaensis Bachmann, Sci. Rep. Kanazawa Univ., 12: 162 , plate 3 , figs. $1-7$.

Remarks. The specimens are furnished with 9 radial spines and an apical apparatus perforated by many small windows.

\section{Cannopilus latifenestratus Bachmann} (Plate 1, Fig. 8)

1964 Cannopilus latifenestratus Bachmann, Sci. Rep. Kanazawa Univ., 9:111, plate 6 , figs. $62-64$.

Remarks. The large, broken specimen possesses no radial spines. The apical windows are nearly as wide as the lateral ones.

\section{Cannopilus picassoi Stradner}

(Plate 1, Fig. 4)

1961 Cannopilus picassoi Stradner, Erdöl Kohle, 14:92, plate 3, figs. 101-104.

Remarks. The single specimen found shows a globular apical apparatus pierced by many small windows.

\section{Genus CORBISEMA Hanna, 1928}

Type species. Corbisema geometrica Hanna, 1928.

Description. Skeleton consisting of a basal ring and an apical apparatus. Basal ring trigonal, with radial spines or spines absent, often bearing septate corners; basal pikes below the struts or pikes absent. Apical apparatus triradiate, sometimes with apical plate. Skeleton seldom tetragonal and with cross-shaped apical apparatus (dictyochid morphes) or digonal and then with apical bridge (naviculopsoid morphes).

Remarks. Usually the species of Corbisema are constructed trigonally but sometimes the main morphes are accompanied by tetragonal forms or, more seldom, also by diagonal ones. At present, there is no sufficient argument to include pentagonal forms in this genus.

\section{Corbisema apiculata (Lemmermann) Hanna (not figured)}

1901 Dictyocha triacantha var. apiculata Lemmermann, Ber. D. Bot. Ges., 19:259, plate 10, figs. 19, 20.

1975 Corbisema apiculata (Lemmermann) in Perch-Nielsen, Init. Repts. DSDP, 29:685, plate 2, figs. $15,16,19$, plate 3, figs. 19,20 , 24 , plate 5, figs. 1,2 .

Remarks. Specimens included here have a triangular basal ring, short radial spines, and also basal pikes. Present in the middle Eocene of Hole 588C, and rare reworked specimens in the middle and upper Miocene at Site 594.

\section{Corbisema cf. apiculata (Lemmermann) Hanna} (not figured)

Remarks. Specimens found in Hole $588 \mathrm{C}$ are somewhat smaller than the nominate species and have less prominent basal pikes. Present (few to common) in the middle Eocene samples of Hole 588C, and also found reworked in a few Miocene samples of Site 594.

\section{Corbisema cf. archangelskiana (Schulz) Frenguelli (not figured)}

1928 Dictyocha triacantha var. archangelskiana Schulz, Bot. Archiv, $21: 250$, figs. 33a-c, $77,78$.

1975 Corbisema archangelskiana (Schulz) in Perch-Nielsen, Init. Repts. DSDP, 29:685, plate 3, figs. 17, 22.

Remarks. Some rare specimens found in the middle Eocene of Hole $588 \mathrm{C}$ may be attributed to this species; they are identical to fig. 5 of plate 7 in Martini and Müller (1976).

\section{Corbisema bimucronata Deflandre (not figured)}

1950 Corbisema bimucronata Deflandre, Microscopie, 2:191, figs. 174-177.

Remarks. Rare specimens found in the lower part of Hole 588C, Core 19, in the middle Eocene (Table 1).

\section{Corbisema convexa (Bukry) n. comb.} (not figured)

1978 Corbisema triacantha ssp. convexa Bukry, Init. Repts. DSDP, 44: 815 , plate 1 , figs. $13-17$.

Remarks. Specimens found in the middle Eocene of Hole $588 \mathrm{C}$, Core 19, seem to represent this species, which was also found in the Naviculopsis foliacea Zone sensu Bukry of DSDP Hole 390A (Core 7), western North Atlantic (Bukry, 1978b).

\section{Corbisema hastata (Lemmermann) Frenguelli (not figured)}

1901 Dictyocha triacantha var. hastata Lemmermann, Ber. D. Bot. Ges., 19:259, plate 10, figs. 16, 17.

1975 Corbisema hastata (Lemmermann), in Perch-Nielsen, Init. Repts. DSDP, 29:685, plate 3, figs. $2-4,8$.

Remarks. Rare specimens were found in samples from Core 19 of Hole $588 \mathrm{C}$, which can be placed in the middle Eocene Naviculopsis foliacea Zone.

\section{Corbisema spinosa Deflandre (not figured)}

1950 Corbisema spinosa Deflandre, Microscopie, 2:193, figs. 178-182. 1976 Corbisema spinosa Deflandre, in Martini and Müller, Init. Repts. DSDP, 38:869, plate 7 , fig. 9 .

Remarks. Rare specimens were encountered in Sample 588C-19,CC (middle Eocene, Naviculopsis foliacea Zone).

\section{Corbisema triacantha (Ehrenberg) Hanna}

(Plate 2, figs. 1, 2; Plate 11, Fig. 1)

1845 Dictyocha triancantha Ehrenberg, Ber. Akad. Wiss. Berlin, 1844: 80 . 
1931 Corbisema triacantha (Ehrenberg) in Hanna, Mining Calif., p. 198 , plate D, fig. 1 .

1974 Corbisema triacantha (Ehrenberg) in Locker, Eclog. Geol. Helv., $67: 634$, plate 1 , fig. 10 (=holotype).

Remarks. The specimens included range from smaller to larger ones. Smaller skeletons are provided with basal bars which are more convex than in larger specimens. Radial spines are usually long.

\section{Genus DICTYOCHA Ehrenberg, 1840}

1838 Dictyocha Ehrenberg, Abh. Akad. Wiss. Berlin, 1836:132 (nomen nudum).

1840 Dictyocha Ehrenberg, Abh. Akad. Wiss. Berlin, 1838:128-129. Type species. Dictyocha fibula Ehrenberg, 1840.

Typification. Frenguelli (1940) selected Dictyocha fibula Ehrenberg, 1840 , as type of the genus. This selection was generally acknowledged but several questions remained about the nature of the type. As shown in the species description, Ehrenberg's intentions about the species and also the protologue belonging to the diagnosis (Ehrenberg, 1840) were neglected for more than a century.

Description. Skeleton consisting of a basal ring and an apical apparatus. Basal ring tetragonal, pentagonal, or hexagonal?, usually with radial spines; basal pikes below or close to the struts, or pikes absent. Apical apparatus composed of struts and an apical bar, the bar simple or complex?, sometimes with an apical pike. Skeleton seldom trigonal (corbisemoid variants) or digonal (naviculopsoid variants) and then often supporting a reduced apical apparatus. The regular basal ring sometimes surmounted by an apical ring (distephanoid morphes) or a fenestrate apical apparatus (cannopiloid morphes). For details see Table 5 .

Remarks. Most of the Dictyocha species are provided with a tetragonal basal ring and a simple apical bar, but relatively often pentagonal forms with an additional strut are developed in addition to the main morphes. Trigonal or digonal specimens with a reduced apical apparatus are rarely present in the populations, and they are probably more abnormal variants. Most of the hexagonal skeletons possessing a complex apical bar certainly belong to populations of Distephanus (dictyochid morphes), but some of them may in fact exhibit independent species of Dictyocha.

The bulk of the Dictyocha species are distinguished by the orientation of the apical bar and the general outline of the basal ring. Differences among species where the apical bar is aligned with the long axis are usually slight, but in many cases they are significant. This is also true for species with the bar along the short axis.

\section{Dictyocha aegea Stradner and Bachmann}

(Plate 2, Fig. 13)

1978 Dictyocha aegea Stradner and Bachmann, Init. Repts. DSDP, 42:805-806, text-fig. 1, plate 1 , figs. 12(?), 13-16.

Remarks. The relatively robust specimen found in Sample 591B5,CC (upper Miocene) corresponds in shape and dimensions to those from the type material.

\section{Dictyocha eocaenica (Krotow)} (not figured)

1960 Dictyocha fibula f. eocaenica Krotov in Gleser, Geol. Inst. Inf. Sborn., 35:131, plate 2, fig. 9.

Remarks. The fibuloid silicoflagellates in the Paleocene and Eocene in general need detailed study. Currently, specimens found in the middle Eocene of Hole 588C (Core 19) are best placed with Dictyocha eocaenica.

\section{Dictyocha epiodon Ehrenberg}

(Plate 2, Fig. 16)

1845 Dictyocha epiodon Ehrenberg, Ber. Akad. Wiss. Berlin, 1844: 79.

1854 Dictyocha epiodon Ehrenberg in Ehrenberg, Mikrogeologie, plate 18, fig. 55; non plate $35 \mathrm{~A}$ and $35 \mathrm{~B}$ (=other taxa).

1974 Dictyocha epiodon Ehrenberg in Locker, Eclog. Geol. Helv., 67: 634-635, plate 1 , figs. 4, 5 (= lectotype, syntype), non figs. 1, 7, 8 (= other taxa).

Remarks. The single but typical specimen possesses a large basal ring surmounted by a short apical bar. Basal pikes are present. Found in Sample 591B-21,CC (middle Miocene).

Dictyocha extensa (Locker) n. comb.

(Plate 2, Figs. 10-12; Plate 11, Fig. 3)

1975 Dictyocha varia f. extensa Locker, Z. Geol. Wiss. Berlin, 3:99101 , figs. $1 / 2,3 / 3$.

Remarks. This taxon is separated here from Dictyocha varia and includes specimens with an elongated basal ring and basal bars which

Table 5. Structure of some Dictyocha and Distephanus species: subspecies and common forms.

\begin{tabular}{|c|c|c|c|c|}
\hline $\begin{array}{l}\text { Dictyocha messanensis } \mathrm{H} \\
\text { D. messanensis ssp. aculeata (L) } \\
\text { D. messanensis ssp. aspinosa (B) } \\
\text { D. messanensis } \mathrm{H} \text { ssp. messanensis } \\
\text { D. messanensis } \mathrm{ssp} \text {. stapedia }(\mathrm{H})\end{array}$ & $\begin{array}{l}4 \mathrm{rs} / \mathrm{ab} / 1 \text { ap } \\
\text { f. aculeata } \\
\text { f. messanensis } \\
\text { f. stapedia }\end{array}$ & $\begin{array}{l}4 \mathrm{rs} / \mathrm{ab} / 0 \text { ap } \\
\text { f. aspinosa }(\mathrm{nm}) \\
\text { f. aspinosa } \\
\text { f. aspinosa }(\mathrm{nm}) \\
\text { f. aspinosa }(\mathrm{nm})\end{array}$ & $4 \mathrm{rs} / \mathrm{ar} / 0-1$ ap & $5 \mathrm{rs} / \mathrm{ab} / 0-1$ ap \\
\hline Dictyocha perlaevis $\mathrm{F}$ & $\begin{array}{l}4 \mathrm{rs} / \mathrm{ab} \\
\mathrm{f} . \text { perlaevis }\end{array}$ & & & $\begin{array}{l}5 \mathrm{rs} / \mathrm{ab} \\
\text { f. pentaradiata } \mathrm{n} . \mathrm{f} \text {. }\end{array}$ \\
\hline $\begin{array}{l}\text { Distephanus crux (E) } \\
\text { Distephanus crux ssp. bispinosus D } \\
\text { D. crux (E) ssp. crux } \\
\text { D. crux ssp. hannai B }\end{array}$ & $\begin{array}{l}4 \mathrm{rs} / \mathrm{ar} / 0 \text { ap } \\
\text { f. crux }(\mathrm{nm}) \\
\text { f. crux } \\
\text { f. hannai }\end{array}$ & $\begin{array}{l}4 \mathrm{rs} / \mathrm{ar} / 1-2 \text { ap } \\
\mathrm{f} . \text { bispinosus }\end{array}$ & $\begin{array}{l}4 \mathrm{rs} / \mathrm{ar} / 3-4 \text { ap } \\
\text { f. mesophthalmus }(\mathrm{E})\end{array}$ & $\begin{array}{l}4 \mathrm{rs} />1 \text { aw } \\
\text { Known, not named } \\
\text { Known, not named }\end{array}$ \\
\hline \multirow[t]{2}{*}{ Distephanus aculeatus (E) } & $\begin{array}{l}5 \mathrm{rs} / \mathrm{ar} \\
\text { Known, not named }\end{array}$ & $\begin{array}{l}6 \mathrm{rs} / \mathrm{ar} \\
\mathrm{f} . \text { aculeatus }\end{array}$ & $\begin{array}{l}7 \mathrm{rs} / \mathrm{ar} \\
\text { f. ornamentum (E) }\end{array}$ & $8 \mathrm{rs} / \mathrm{ar}$ \\
\hline & $\begin{array}{l}5 \mathrm{rs} />1 \text { aw } \\
\text { Known, not named }\end{array}$ & $\begin{array}{l}6 \mathrm{rs} />1 \text { aw } \\
\text { f. binoculus (E) }\end{array}$ & $\begin{array}{l}7 \mathrm{rs} />1 \text { aw } \\
\text { Known, not named }\end{array}$ & \\
\hline \multirow[t]{3}{*}{ Distephanus speculum (E) } & $\begin{array}{l}5 \mathrm{rs} / \mathrm{ar} \\
\mathrm{f} . \text { pentagonus }(\mathrm{L})\end{array}$ & $\begin{array}{l}6 \mathrm{rs} / \mathrm{ar} \\
\text { f. speculum }\end{array}$ & $\begin{array}{l}7 \mathrm{rs} / \mathrm{ar} \\
\text { f. septenarius (E) }\end{array}$ & $\begin{array}{l}8 \mathrm{rs} / \mathrm{ar} \\
\text { f. octonarius (E) }\end{array}$ \\
\hline & $\begin{array}{l}5 \mathrm{rs} />1 \text { aw } \\
\text { f. cannopilus-pentagona }(\mathrm{F})\end{array}$ & $\begin{array}{l}6 \mathrm{rs} />1 \text { aw } \\
\text { f. cannopilus-hexacantha }(\mathrm{F})\end{array}$ & $\begin{array}{l}7 \mathrm{rs} />1 \text { aw } \\
\text { Known, not named }\end{array}$ & \\
\hline & $\begin{array}{l}5 \mathrm{rs} / \mathrm{ab} \\
\text { f. pentagonalis (A) }\end{array}$ & $\begin{array}{l}6 \mathrm{rs} / \mathrm{ab} \\
\text { f. varians } \mathrm{G}+\mathrm{B} \\
\text { f. pseudofibula } \mathrm{S}\end{array}$ & $7 \mathrm{rs} / \mathrm{ab}$ & \\
\hline
\end{tabular}

Note: Nominate forms or antonyms are given without author; non-nominate but structurally identical forms within different subspecies are marked $(\mathrm{nm})$; described forms and transferred taxa are cited with author $(\mathrm{A}=$ Aurivillius, $\mathrm{B}=$ Bukry, $\mathrm{D}=\mathrm{Dumitrică}, \mathrm{E}=\mathrm{Ehrenberg}, \mathrm{F}=\mathrm{Frenguelli}$ $\mathrm{G}+\mathbf{B}=$ Gran and Braarud, $\mathrm{H}=$ Haeckel, $\mathrm{L}=$ Lemmermann, $\mathrm{S}=$ Schulz). Abbreviations refer to combinations of skeletal elements (ab $=$ apical bar, ap = apical pike, ar $=$ apical ring, aw = apical window, $\mathrm{rs}=$ radial spine). 
are distinctly convex. The short apical bar is aligned with the long axis. Few to common in the middle Miocene to lower Pliocene of Site 591.

\section{Dictyocha fibula Ehrenberg}

Remarks. Dictyocha fibula is treated here as a group of subspecies. The species is generally characterized by a large basal ring, usually tetragonal in outline, and an apical bar arranged along the short axis. The subspecies indicated may be distinguished by the shape of the skeleton and the proportions of the skeletal elements.

\section{D. fibula ssp. asymmetrica n. ssp. (Plate 4, Figs. 1-6)}

Holotype. SM.B 13508; Plate 4, Fig. 1.

Type locality. Lord Howe Rise, DSDP Sample 591B-21,CC (middle Miocene).

Description. Basal ring tetragonal, usually asymmetrical, furnished with four radial spines. Basal pikes generally small and directly beneath the struts. Apical apparatus composed of an apical bar and four struts, the bar along the short axis, reaching one-third of the short diameter. Length, $62-93 \mu \mathrm{m}$.

Remarks. This new subspecies may be distinguished from similar taxa by the rather conspicuous shape of the skeleton. The basal ring usually exhibits an asymmetrical outline, causing slight divergence of the radial spines aligned with the long axis. Commonly all apical elements, bar and struts, are more delicate than the basal ones.

\section{D. fibula Ehrenberg ssp. fibula}

(Plate 5, Figs. 1, 2; Plate 11, Figs. 8, 9)

1838 Dictyocha fibula Ehrenberg, Abh. Akad. Wiss. Berlin, 1836:132 (nomen nudum)

1840 Dictyocha fibula Ehrenberg, Abh. Akad. Wiss. Berlin, 1838:129. 1854 Dictyocha fibula Ehrenberg in Ehrenberg, Mikrogeologie, plate

21 , figs. $42 \mathrm{a}-\mathrm{b}$, plate 22 , figs. $42 \mathrm{a}-\mathrm{b}$, non figure $42 \mathrm{c}$, plate 36 , fig. C 37 , non plates $18-20,33 \mathrm{~B}$ ( = other taxa).

1974 Dictyocha fibula Ehrenberg in Locker, Eclog. Geol. Helv., 67: 636 , plate 1 , fig. 6 (=lectotype), figures $3,9,11$ (=other types).

Typification. The species was first indicated without a description or figure from Oran in Algeria (Ehrenberg, 1838). Therefore the type selection by Locker (1974) was in accordance to ICBN rules (recommendation 7B and article 8.1), and the species must now be restricted to the large Miocene specimens bearing the apical bar along the short axis.

Remarks. The specimens referred to this subspecies correspond in shape and dimensions to the type specimens. The basal ring generally shows a rhomboidal outline with bars usually slightly convex. The apical bar may vary in length.

\section{Dictyocha fibula Ehrenberg s.l. (Plate 5, Fig. 3)}

Remarks. The specimens placed into this group are heterogeneous in their habitus. Angulate rhomboidal skeletons, elongate rounded, and angulate specimens are included. This group needs special investigation so that specimens may be better discriminated.

\section{Dictyocha medusa Haeckel}

(Plate 2, Figs. 14, 15; Plate 11, Fig. 6)

1887 Dictyocha medusa Haeckel, Rep. Sci. Res. Voy. Challenger, 18: 1560 , plate 101 , figs. 13,14 .

Remarks. This species is characterized by a cross-shaped apical apparatus. It may be polyphyletic because one group of individuals shows affinities to Dictyocha varia and another to $D$. extensa. The first group exhibits an apical cross slightly broadened along the short axis, the latter group a cross slightly broadened along the long axis.

Another possible explanation of the relationship would be to assume a variational continuum across the three taxa indicated, forming a line Dictyocha varia $-D$. medusa $-D$. extensa. This would at least enable us to erect three forms within one species.

\section{Dictyocha messanensis Haeckel}

Remarks. Dictyocha messanensis demonstrates a very complicated intraspecific structure. As illustrated in Table 5, some subspecies con- taining forms may be distinguished. The species is generally characterized by a basal ring, usually tetragonal in outline, and by an apical bar strongly aligned with the long axis. The subspecies may be distinguished by the outline of the skeleton and the presence of an apical pike. The forms may be discriminated by the number of radial spines and the structure of the apical apparatus.

The early Miocene $D$. messanensis ssp. aspinosa has no apical pike (only f. aspinosa). This feature is first developed in the late Miocene D. messanensis ssp. stapedia, which also contains spineless specimens in its population (f. stapedia and f. aspinosa). Besides the last mentioned subspecies, $D$. messanensis ssp. messanensis occurs in some areas, and also comprises variants with and without an apical pike (f. messanensis and f. aspinosa). The same mode of variation appears in the Quaternary D. messanensis ssp. aculeata (f. aculeata and f. aspinosa).

Typification. The species as a whole is here called $D$. messanensis. The name $D$. trifenestra given by Ehrenberg (1843) would have priority in at least one subgroup, but because the name of Haeckel is widely accepted in oceanographic literature and the name of Ehrenberg has been neglected for over a hundred years, $D$. messanensis is preferred even though this is not fully in accordance with the ICBN.

Dictyocha messanensis ssp. aculeata (Lemmermann) n. comb.

1901 Dictyocha fibula var. aculeata Lemmermann, Ber. D. Bot. Ges., 19:261, Plate 11, Figs. 1, 2.

1973 Dictyocha aculeata (Lemmermann) in Dumitrică, Init. Repts. DSDP, 13:907, plate 9, figs. 5-10.

1977 Dictyocha mandrai Ling, Proc. First Int. Cong. Pacific Neogene

Strat., pp. 209-210, plate 1, figs. 13, 14.

Remarks. This subspecies possesses a basal ring which is more or less rhomboidal in outline. The basal bars are distinctly bent outward and have additional pikes between the radial spines. Specimens found can be placed into f. aculeata and f. aspinosa (for characters see Table 5).

Dictyocha messanensis ssp. aculeata (Lemmermann) f. aculeata (Plate 3, Figs. 11, 12)

\section{Dictyocha messanensis ssp. aculeata (Lemmermann) f. aspinosa (nm) \\ (not figured)}

Dictyocha messanensis ssp. aspinosa (Bukry) n. comb. (Plate 3, Figs. 3-5; Plate 12, Fig. 2)

1976 Dictyocha stapedia ssp. aspinosa Bukry, Init. Repts. DSDP, 34: 724 , plate 2 , figs. $6-9$.

Remarks. This subspecies shows a basal ring slightly elongated. The radial spines are relatively short but also elongated parallel to the long axis. The apical bar does not have a pike.

\section{D. messanensis Haeckel ssp. messanensis}

1843 Dictyocha fibula var. $\beta$ Ehrenberg, Abh. Akad. Wiss. Berlin, $1841: 312$, plate 2 , fig. IV 11 .

1861 Dictyocha messanensis Haeckel in Peters, Ber. Akad. Wiss. Berlin, 1860:799-800.

1861 Dictyocha tenella Ehrenberg, Ber. Akad. Wiss. Berlin, 1860:767.

Remarks. This subspecies exhibits a distinctly rhomboidal basal ring; the radial spines are relatively long. The apical bar varies in length but often may be short. Most of the specimens found belong to f. aspinosa, but some specimens can be placed with f. messanensis and f. speculum (for characters see Table 5).

\section{D. messanensis Haeckel ssp. messanensis f. aspinosa (nm)} (Plate 3, Figs. 1, 9)

Dictyocha messanensis Haeckel ssp. messanensis f. messanensis (Plate 3, Fig. 10)

Dictyocha messanensis ssp. messanensis f. speculum (Frenguelli) n. comb. (Plate 3, Fig. 8)

1935 Dictyocha fibula f. speculum Frenguelli, An. Mus. Argent. Cienc. Nat., 38 (Protistol. 4):277, plate 5, figs. 1-9, plate 6, figs. 1-8. 
Dictyocha messanensis ssp. stapedia (Haeckel) n. comb.

1887 Dictyocha stapedia Haeckel, Rep. Sci. Res. Voy. Challenger, 18:

1561 , plate 101 , figs. 10-12.

Remarks. This subspecies shows a basal ring usually elongated; the radial spines are also elongated parallel to the long axis. Basal bars are generally more bent than in $D$. messanensis ssp. messanensis. The apical bar varies in length from one-third to one-half of the basal ring. Specimens found belong to f. aspinosa and f. stapedia (for characters see Table 5).

Dictyocha messanensis ssp. stapedia (Haeckel) f. aspinosa (nm) (Plate 3, Fig. 2; Plate 11, Fig. 2)

\section{D. messanensis ssp. stapedia (Haeckel) f. stapedia} (Plate 3, Figs. 6, 7)

\section{Dictyocha perlaevis Frenguelli}

1951 Dictyocha perlaevis Frenguelli, Physis, 20:279, figs. 4b-c.

Remarks. This species resembles $D$. messanensis ssp. aspinosa and ssp. stapedia in shape but is generally larger. Commonly, basal pikes are not developed. The apical bar ranges in length from one-fifth to one-third of the basal ring. Most of the specimens found belong to $f$. perlaevis; only a few specimens could be placed into f. pentaradiata.

\section{Dictyocha perlaevis f. pentaradiata n. f.}

(Plate 5, Fig. 6)

Holotype. SM.B 13509; Plate 5, Fig. 6.

Type locality. Lord Howe Rise, DSDP Sample 591-20,CC (lower Pliocene).

Description. Basal ring pentagonal, with 5 radial spines, but usually without pikes. Basal bars slightly constricted at junctions of struts. Apical apparatus composed of a crooked apical bar supported by 5 struts. Size: $55 \mu \mathrm{m}$.

Remarks. This new form may be differentiated from similar taxa of other species by the dimensions of the skeleton and the shape of basal bars, which are bent like the nominal form.

\section{Dictyocha perlaevis Frenguelli f. perlaevis}

(Plate 5, Fig. 5; Plate 12, Fig. 1)

Dictyocha sp. 1

(Plate 5, Fig. 4)

Remarks. The specimens found in the lower Pliocene of Site 591 consist of a tetragonal basal ring which is surmounted by some remnants of an apical apparatus. The apical bar, aligned with the long axis, appears reduced or aberrantly joined with the basal ring. They may be related to $D$. perlaevis.

\section{Dictyocha pygmaea (Ciesielski) n. comb.}

(Plate 2, Fig. 6)

1975 Dictyocha aspera var. pygmaea Ciesielski, Init. Repts. DSDP, $28: 655$, plate 4 , figs. $1,3,4,6$.

Remarks. The small specimens exhibit a basal ring more or less rhomboidal in outline and an apical bar aligned with the short axis. Radial spines are relatively long. Rare in the Miocene of Sites 591 and 594.

Dictyocha sp. 2

(Plate 2, Fig. 7; Plate 11, Fig. 7)

Remarks. Specimens are small and consist of a tetragonal basal ring which has distinctly curved bars. The apical bar is arranged along the short axis. Radial spines are short. The species may be related to $D$. pygmaea or $D$. varia. Present in the uppermost Miocene and lower Pliocene of Site 591 .

\section{Dictyocha sp. 3}

(Plate 2, Fig. 8)

Remarks. The small specimens show a basal ring which is more or less rhomboidal in outline. The apical bar is aligned with the short axis. Radial spines are short. Relationships to D. pygmaea and also to Dictyocha sp. 2 may be possible. Rare in the middle Miocene of Site 594.

\section{Dictyocha subclinata Bukry}

(Plate 2, Fig. 9)

1981 Dictyocha subclinata Bukry, Init. Repts. DSDP, 63:546-547, plate 1 , figs. $4-8$, plate 2 , figs. $1-5$, non figs. $6-10$ (=other taxon).

Remarks. Specimens found are similar in shape to Dictyocha varia except that the bar is arranged more obliquely. The radial spines parallel to the long axis are rather long. Present in the basal upper Miocene of Site 591 .

Dictyocha varia Locker

(Plate 2, Figs. 3-5; Plate 11, Figs. 4, 5)

1975 Dictyocha varia Locker, Z. Geol. Wiss. Berlin, 3:99-100, textfigs. $1 / 1,3 / 1$, non $1 / 2,1 / 3,3 / 2,3 / 3$ (=other taxon).

1975 Dictyocha pulchella Bukry, Init. Repts. DSDP, 32:687, plate 4,

figs. 1-3.

Remarks. In typical cases specimens exhibit a basal ring with bars which are distinctly convex. But variation may also include more rhomboidal skeletons. The apical bar is generally aligned with the short axis. Radial spines vary in length. The species is rather abundant throughout the middle Miocene to lower Pliocene at Site 591; it is less common and occurs sporadically at Site 594 .

\section{Genus DISTEPHANUS Stöhr, 1880}

Type species. Distephanus rotundus Stöhr, 1880, probably = Dictyocha speculum Ehrenberg, 1840.

Description. Skeleton consisting of a basal ring and an apical apparatus. Basal ring tetragonal to polygonal, usually with radial spines; basal pikes below or close to the struts, or pikes absent. Apical apparatus composed of struts and an apical ring which may be large or narrow, sometimes with apical pikes. The regular basal ring in some cases surmounted by a complex apical bar (dictyochid morphes) or a fenestrate apical apparatus (cannopiloid morphes).

Remarks. Species of Distephanus normally have an apical ring but in some populations morphes with a complex apical bar or, more often, with an apical apparatus showing several windows, are present in greater numbers. Distinguishing cannopiloid forms belonging to $\mathrm{Di}$ stephanus from normal variants of Cannopilus may be difficult, especially if they are found in the same material. But in many cases differentiation is possible by the size range of the basal ring, its general shape, and the number of apical windows.

\section{Distephanus aculeatus (Ehrenberg) Haeckel}

1841 Dictyocha aculeata Ehrenberg, Abh. Akad. Wiss. Berlin, 1839: 148-149.

1854 Dictyocha aculeata Ehrenberg in Ehrenberg, Mikrogeologie, plate 19 , fig. 40 , non plates 21,22 (=other taxa).

1887 Distephanus aculeatus (Ehrenberg) in Haeckel, Rep. Sci. Res. Voy. Challenger, 18:1565.

1940 Dictyocha boliviensis Frenguelli, Rev. Mus. La Plata, 2(Pal. 7): 44, fig. $4 \mathrm{a}$, non figs. $4 \mathrm{~b}-\mathrm{d}$ (=other taxon).

1974 Distephanus aculeatus (Ehrenberg) in Locker, Eclog. Geol. Helv., 67:637, plate 3 , fig. 5 (=lectotype), figs. 6,9 (=intraspecific taxa of Distephanus aculeatus).

Remarks. This large species shows a basal ring with radial spines which are usually about equal in length. The apical ring normally has no pikes. Most of the specimens found scattered throughout the middle Miocene to Pliocene at Sites 591 and 594 belong to f. aculeatus but some can be placed into f. binoculus (for characters see Table 5).

\section{Distephanus aculeatus (Ehrenberg) f. aculeatus} (Plate 6, Fig. 5)

\section{Distephanus aculeatus f. binoculus (Ehrenberg) n. comb.} (Plate 6, Figs. 11, 12)

1843 Dictyocha binoculus Ehrenberg, Ber. Akad. Wiss. Berlin, 1842: 265 (nomen nudum).

1845 Dictyocha binoculus Ehrenberg, Ber. Akad. Wiss. Berlin, 1844: 79.

1854 Dictyocha binoculus Ehrenberg in Ehrenberg, Mikrogeologie, plate 19 , fig. 42.

1974 pars Distephanus aculeatus (Ehrenberg) in Locker, Eclog. Geol. Helv., 67:637, plate 3, fig. 6 (=holotype), non figs. 5, 9 (=other intraspecific taxa of $D$. aculeatus). 


\section{Distephanus crux (Ehrenberg) Haeckel}

Remarks. Distephanus crux is regarded here as a group of subspecific taxa. The species is generally characterized by a tetragonal basal ring surmounted by an apical ring. The subspecies indicated may be distinguished by the outline of the skeleton and the presence of apical pikes.

\section{Distephanus crux ssp. bispinosus Dumitrică}

1973 Distephanus crux ssp. bispinosus Dumitrică, Init. Repts. DSDP, $21: 850$, plate 6 , figs. $3,6,7$.

Remarks. This subspecies has a basal ring very similar in shape to Distephanus crux ssp. crux, but the apical ring generally supports apical pikes. According to the number of pikes, 3 forms can be distinguished: f. crux, f. bispinosus, and f. mesophthalmus (for characters see Table 5).

\section{Distephanus crux ssp. bispinosus Dumitrică f. bispinosus (Plate 6, Figs. 1-3)}

Distephanus crux ssp. bispinosus Dumitrică f. crux (nm) (not figured)

Distephanus crux ssp. bispinosus f. mesophthalmus (Ehrenberg) n. comb.

(Plate 6, Fig. 4)

1845 Dictyocha mesophthalma Ehrenberg, Ber. Akad. Wiss. Berlin, 1844:80.

1854 Dictyocha mesophthalma Ehrenberg in Ehrenberg, Mikrogeologie, plate 22, fig. 43 .

1887 Distephanus mesophthalmus (Ehrenberg) in Haeckel, Rep. Sci. Res. Voy. Challenger, 18:1563-1564.

1974 pars Distephanus crux (Ehrenberg) in Locker, Eclog. Geol. Helv. 67:637, plate 3 , fig. 8 (=holotype, revised), non fig. 10 (=other intraspecific taxon of Distephanus crux).

\section{Distephanus crux (Ehrenberg) ssp. crux}

(Plate 6, Figs. 6, 7)

1841 Dictyocha crux Ehrenberg, Ber. Akad. Wiss. Berlin, 1840: 207-208.

1845 Dictyocha staurodon Ehrenberg, Ber, Akad. Wiss. Berlin, 1844: 80.

1854 Dictyocha crux Ehrenberg in Ehrenberg, Mikrogeologie, plate 18 , figs. $56 a-c$, plate 20 , fig. I 46 , plate 33 , figs. B XV 9, B XVI 9 , B XVII 5.

1854 Dictyocha staurodon Ehrenberg in Ehrenberg, Mikrogeologie, plate 18, fig. 58.

1887 Distephanus crux (Ehrenberg) in Haeckel, Rep. Sci. Res. Voy. Challenger, 18:1563.

1974 Distephanus crux (Ehrenberg) in Locker, Eclog. Geol. Helv., 67: 637, plate 3, fig. 10 (=lectotype of Dictyocha staurodon), non fig. 8 (= holotype of Dictyocha mesophthalma, revised).

Remarks. This subspecies exhibits a basal ring that is commonly rhomboidal in outline. The apical ring varies in width. The radial spines are arranged parallel to the long axis, normally reaching onehalf the length of the basal ring.

Typification. Under the name "Dictyocha Crux" Ehrenberg figured on plates 411 and 2319 in his "Microgeological Collection" at Berlin the specimens previously indicated as lectotype (Locker, 1974). Because no other syntypes could be detected in the collection, this selection seemed to solve the problem, but it must be revised. It seems possible that Ehrenberg used on two other occasions the specimen figured in the collection and in his Mikrogeologie (1854): first in 1841 as part of the Dictyocha crux type series, and secondly in 1845 as type for the new taxon Dictyocha mesophthalma. To distinguish between both taxa, the "lectotype" of Dictyocha crux (Locker, 1974) is revised here to represent the holotype of $D$. mesophthalma. Consequently, no type specimen is at present available for $D$. crux.

\section{Distephanus crux ssp. hannai Bukry} (Plate 6, Fig. 13)

1975 Distephanus crux ssp. hannai Bukry, Init. Repts. DSDP, 29:855, plate 4 , figs. 4-6.
1977 Distephanus pussillus Ling, Proc. 1st Int. Cong. Pacific Neog. Strat., Tokyo, pp. 211-212, plate 2, figs. 18-21.

Remarks. This large subspecies possesses a basal ring distinctly constricted at the struts. The basal bars are therefore commonly strongly curved. The apical ring is rather narrow.

\section{Distephanus polyactis (Ehrenberg) Deflandre}

Remarks. Distephanus polyactis is characterized by a wide basal ring possessing many radial spines but never pikes, and a rather large apical ring. The two subspecies may be distinguished by their dimensions, by the compactness of the skeleton, and by the proportions of main skeletal elements.

\section{Distephanus polyactis ssp. crassus Bukry}

(Plate 5, Fig. 7)

1977 Distephanus polyactis ssp. crassus Bukry, Init. Repts. DSDP, 37:922, plate 1 , figs. 7-14.

Remarks. This subspecies has a basal ring armed with 6 to 9 short radial spines, more or less equal in length. The basal ring, missing any pikes, is surmounted by a very high and wide apical ring. The subspecies may be distinguished from the similar Distephanus speculum ssp. giganteus by the length of radial spines and the absence of basal pikes.

\section{Distephanus polyactis (Ehrenberg) ssp. polyactis}

(Plate 5, Figs. 8, 9)

1840 Dictyocha polyactis Ehrenberg, Abh. Akad. Wiss. Berlin, 1838: 129.

1854 Dictyocha polyactis Ehrenberg in Ehrenberg, Mikrogeologie, plate 22, fig. 50 .

1932 Distephanus polyactis (Ehrenberg) in Deflandre, Bull. Soc. Bot. France, 79:497, 501.

1940 Paradictyocha polyactis (Ehrenberg) in Frenguelli, Rev. Mus. La Plata, 2(Pal. 7):51, text-figs. $7 \mathrm{f}-\mathrm{g}, 8 \mathrm{a}$; non $8 \mathrm{~b}-\mathrm{e}$ (=other taxon). 1974 Distephanus polyactis (Ehrenberg) in Locker, Eclog. Geol. Helv., 67:637, plate 4 , fig. 2 (=holotype).

Remarks. This subspecies shows a very large basal ring with 7 to 16 radial spines, rather short and nearly equal in length. The basal ring has no pikes and supports a very large diameter apical ring. The subspecies may be distinguished from $D$. polyactis ssp. crassus by the greater dimensions and the higher number of radial spines.

\section{Distephanus speculum (Ehrenberg) Haeckel}

Remarks. Distephanus speculum has a very complex intraspecific structure. As illustrated in Table 5, two subspecies and many forms may be distinguished. The species is generally characterized by a basal ring, commonly hexagonal in outline, and by an apical ring decorated with pikes. The subspecies indicated may be discriminated by their dimensions, by the compactness of the skeleton, and by the presence of apical pikes. The forms may be determined by the number of radial spines and the structure of the apical apparatus. Note that for undifferentiated middle Eocene taxa D. speculum s.l. is used.

\section{Distephanus speculum ssp. giganteus Bukry}

1976 Distephanus speculum ssp. giganteus Bukry, Init. Repts. DSDP, $38: 848-849$, plate 1 , fig. 19 , plate 2 , figs. 1,2 .

Remarks. This subspecies possesses a very robust basal ring and commonly has 6 radial spines, but basal pikes are often minute. The apical ring does not support any pikes. Most specimens encountered belong to f. giganteus, but some specimens with 5 radial spines can be placed into f. pentagonus.

\section{Distephanus speculum ssp. giganteus Bukry f. giganteus} (Plate 7, Figs. 14, 15)

\section{D. speculum ssp. giganteus Bukry f. pentagonus (nm) (not figured)}

\section{D. speculum (Ehrenberg) ssp. speculum}

1838 Dictyocha speculum Ehrenberg, Abh. Akad. Wiss. Berlin, 1836: 132 (nomen nudum). 
1840 Dictyocha speculum Ehrenberg, Abh. Akad. Wiss. Berlin, 1838: 129 , plate 4 , figure $X \mathrm{n}$.

1854 Dictyocha speculum Ehrenberg in Ehrenberg, Mikrogeologie, plate 18 , fig. 57 , plate 19 , fig. $41 \mathrm{~b}$, plate 21 , fig. $44 a$, plate 33 , fig. B XIII 6 , non plate 19 , fig. $41 \mathrm{a}$, non plate 21 , fig. $44 \mathrm{~b}$, non plate 22 (=other taxon).

1887 Distephanus speculum (Ehrenberg) in Haeckel, Rep. Sci. Res. Voy. Challenger, 18:1565.

1974 Distephanus speculum (Ehrenberg) in Locker, Eclog. Geol. Helv. 67:638, plate 3 , fig. 2 (=lectotype), figs. $1,3,4,7,11$ (=other types of D. speculum).

Remarks. This subspecies sometimes has a rather small basal ring which commonly bears 6 radial spines. Basal pikes are usually distinct. The apical ring often shows pikes, in the most typical case 2, but any number from 0 to 6 may occur. Besides the most common f. speculum, other forms found in the material were f. pentagonus, f. septenarius, f. octonarius, f. nonarius, f. cannopilea-hexagona, f. pseudofibula, and $\mathrm{f}$. varians (for characters see Table 5).

\section{Distephanus speculum ssp. speculum f. cannopilea-hexacantha (Frenguelli) n. comb. \\ (Plate 7, Fig. 1)}

1935 Dictyocha fibula f. cannopilea-hexacantha Frenguelli, An. Mus. Argent. Cienc. Nat., 38 (Protist. 4): plate 12, figs. 1, 2.

\section{Distephanus speculum ssp. speculum f. nonarius $\mathbf{n}$. f.} (Plate 7, Fig. 7)

Holotype. SM.B 13510; Plate 7, Fig. 7.

Type locality. Chatham Rise, DSDP Sample 594-13,CC (lower Pleistocene).

Description. Basal ring polygonal with 9 radial spines, and basal pikes. Basal bars are slightly concave. Apical apparatus composed of a large apical ring supported by 9 struts. Pikes may be present at the apical ring. Diameter $45 \mu \mathrm{m}$.

Remarks. This new form is distinguished from similar taxa of other species by the dimensions and proportions of the skeleton, by the curvature of basal bars, and the presence of apical pikes.

\section{Distephanus speculum ssp. speculum f. octonarius (Ehrenberg) n. comb. (Plate 7, Fig. 6)}

1845 Dictyocha octonaria Ehrenberg, Ber. Akad. Wiss, Berlin, 1844: 201.

1887 Distephanus octonarius (Ehrenberg) in Haeckel, Rep. Sci. Res. Voy. Challenger, 18:1566.

1959 Dictyocha speculum f. octonarius (Ehrenberg) in ProshkinaLavrenko, Trudy Bot. Inst. Akad. Nauk SSSR, Ser. 2, 12:153.

Remarks. The octogonal form of $D$. speculum speculum may represent one of the more frequent morphes in its own subspecific unit of the Quaternary $D$. speculum. Size relations indicate that the subspecies may comprise a line from six- to nine-spined forms, but this must yet be demonstrated.

\section{Distephanus speculum ssp. speculum f. pentagonus} (Plate 7, Fig. 8)

1901 Distephanus speculum var. pentagonus Lemmermann, Ber. D Bot. Ges., 19:264, plate 11, fig. 19.

Distephanus speculum ssp. speculum f. pseudofibula Schulz (Plate 7, Fig. 11)

1928 Distephanus speculum f. pseudofibula Schulz, Bot. Archiv, 21 262, figs. 51a-b.

Distephanus speculum ssp. speculum f. septenarius (Ehrenberg) n. comb.

(Plate 7, Fig. 5)

1845 Dictyocha septenaria Ehrenberg, Ber. Akad. Wiss. Berlin, 1844: 80 .

1854 Dictyocha septenaria Ehrenberg in Ehrenberg, Mikrogeologie, plate 21 , fig. 45 , plate $35 \mathrm{~A}$, fig. B XXI 8 .

1974 pars Distephanus speculum (Ehrenberg) in Locker, Eclog. Geol. Helv., 67:638, plate 3 , fig. 1 (=holotype), non figs. $2-4,7,11$ (=other intraspecific taxa of $D$. speculum).
Distephanus speculum (Ehrenberg) ssp. speculum f. speculum (Plate 7, Figs. 2-4)

Distephanus speculum ssp. speculum f. varians Gran and Braarud (Plate 7, Figs. 9, 10)

1935 Distephanus speculum f. varians Gran and Braarud, J. Biol. Board Can., 1:390, text-figs. 68A-B.

\section{Distephanus sp.}

(Plate 7, Fig. 12)

Remarks. The specimens included here have a hexagonal basal ring without any apical elements. Only short basal pikes are present and are oriented toward the center. The skeletons usually are very delicate; they were treated as a new taxon by Bukry (1982b), Distephanus speculum ssp. tenuis, which indicates the relationship to $D$. speculum.

\section{Distephanus speculum (Ehrenberg) Haeckel s.l. (not figured)}

Remarks. In the middle Eocene of Hole $588 \mathrm{C}$ several 6-sided specimens having the general appearance of $D$. speculum were found in Core 19. For a detailed study more material is needed, but at present 3 groups are differentiated for practical use (see Table 1). D. speculum s.l. is hexagonal, with a 6-sided single apical window, D. speculum s.1. f. 1 includes specimens which also have 6 struts supporting an apical apparatus of 3 windows, but $D$. speculum s.l. f.2 includes specimens in which the apical structure is reduced to a trifurcated bar supported by 6 struts. Specimens of the latter variant are frequently found in the middle Eocene of Hole $588 \mathrm{C}$.

\section{Distephanus stauracanthus (Ehrenberg) Haeckel}

1846 Dictyocha stauracanthus Ehrenberg, Ber. Akad. Wiss. Berlin, 1845:76.

1854 Dictyocha stauracanthus Ehrenberg in Ehrenberg, Mikrogeologie, plate 33, fig. B XV 10, non plate 33 (=other taxon).

1887 Distephanus stauracanthus (Ehrenberg) in Haeckel, Rep. Sci. Res. Voy. Challenger, 18:1564.

1956 Distephanus crux var. octacanthus Desikachary and Maheshwari, J. Ind. Bot. Soc., 35:260, text-figs. 10, 12, 13, plate 13, figs. 8, 9.

1971 Dictyocha octacantha (Desikachary and Maheshwari) in Martini, Init. Repts. DSDP, 7:1697, plate 1, fig. 16.

1974 Distephanus stauracanthus (Ehrenberg) in Locker, Eclog. Geol. Helv., 67:638, plate 3, fig. 12 (=lectotype).

Remarks. This species is characterized by an octogonal basal ring armed with 4 radial spines. The rather narrow apical ring shows 4 corners, indicating some relationship to Distephanus crux. Besides f. stauracanthus, one specimen of f. octagonus showing only a single apical bar was found in the present material.

\section{D. stauracanthus f. octagonus (Tsumura) n. comb.}

(Plate 6, Fig. 8)

1963 Dictyocha fibula var. octagona Tsumura, J. Yokohama Univ., C45, no. $146: 55-56$, plate 2 , fig. 4 , plate 10 , figs. $11-13$, plate 23 , figs. $8-10$.

1971 Dictyocha octagona (Tsumura) in Martini, Init. Repts. DSDP, $7: 1697$, plate 1 , fig. 15 .

\section{D. stauracanthus (Ehrenberg) f. stauracanthus}

(Plate 6, Figs. 9, 10)

Remarks. According to available data this form seems to be restricted to the middle Miocene. It is listed as Distephanus stauracanthus Horizon in Tables 2 and 3 (Sites 591 and 594), but is less conspicuous in the high-latitude Site 594.

\section{Genus MESOCENA Ehrenberg, 1841}

1841 Dictyocha (Mesocena) Ehrenberg, Ber. Akad. Wiss. Berlin, 1840: 208.

1843 Mesocena Ehrenberg in Ehrenberg, Abh. Akad. Wiss. Berlin, 1841:401.

1974 Bachmannocena Locker, Eclog. Geol. Helvet., 67:635.

Type species. Mesocena elliptica Ehrenberg, 1841, ex Dictyocha (Mesocena) elliptica Ehrenberg, 1841.

Typification. Ehrenberg (1841) introduced the taxon Mesocena as subgenus of the genus Dictyocha without a description. In the same 
paper he described the species D. (M.) circulus, D. (M.) elliptica and $D$. (M.) triangula as being new. Therefore, according to articles 12 and $16 \mathrm{a}-\mathrm{v}$ of the ICZN (validity by indication) and article 45.4 of the $I C B N$ (validity of algal taxa published under the ICZN) the genus $M e$ socena dates from 1841 and not from 1843, as Loeblich et al. (1968) wrote. It also follows that $M$. elliptica Ehrenberg, 1841, has to be taken as type species; this is in accordance with the first selection of Frenguelli (1940).

Description. Skeleton consisting only of a basal ring, which is digonal to hexagonal, mainly tetragonal, usually with radial spines, but also without spines; basal pikes generally absent.

Remarks. All species with a single skeletal ring can be assigned to three or four genera, depending on their phylogenetic origin. According to the concept of Bachmann (1970), the genus Mesocena is regarded here as derived from Dictyocha, and tetragonal forms are most frequently represented in many populations.

Some species of Mesocena always show 4 radial spines, but most populations are composed of more than one form. In general, the main morphe has an even number $(2,4,6)$ of radial spines, because of the greater morphological stability of symmetrical constructions. Sixrayed mesocenoid species are known, but they are rare. In some cases they may be derived, not from tetragonal Mesocena species along a variation line of 4,5 , or 6 radial spines, but from hexagonal species of Distephanus. If this can be demonstrated, the hexagonal species generated from Distephanus must be removed from Mesocena and placed in a separate genus.

\section{Mesocena diodon Ehrenberg}

(Plate 8, Figs. 3, 4)

1845 Mesocena diodon Ehrenberg, Ber. Akad. Wiss. Berlin, 1844:84. 1854 Mesocena diodon Ehrenberg, in Ehrenberg, Mikrogeologie, plate 33, fig. XV 18.

1974 Bachmannocena diodon (Ehrenberg) in Locker, Eclog. Geol. Helv., 67:636, plate 2, fig. 9 (=lectotype).

Remarks. The species has a large basal ring which is distinctly oval in shape. Usually 2 short radial spines are developed, but in some cases 3 spines or only 1 spine may be present. Size and shape are important in differentiating this species from others.

\section{Mesocena elliptica Ehrenberg}

(Plate 9, Fig. 6)

1841 Dictyocha (Mesocena) elliptica Ehrenberg, Ber. Akad. Wiss. Berlin, 1840:208.

1845 Mesocena elliptica Ehrenberg in Ehrenberg, Ber. Akad. Wiss. Berlin, 1844:71, 84.

1854 Mesocena elliptica Ehrenberg in Ehrenberg, Mikrogeologie, plate 20 , figs. I $44 a-b$.

1974 Mesocena elliptica Ehrenberg in Locker, Eclog. Geol. Helv., 67: 634 , plate 2 , fig. 4 (=lectotype).

Remarks. Specimens so far known have a tetragonal basal ring. Basal bars are usually slightly wavy. Radial spines are short.

\section{Mesocena? hexalitha Bukry}

1981 Mesocena hexalitha Bukry, Init. Repts. DSDP, 63:547-548, plate 5, Figs. 5-10.

Remarks. This species usually has a hexagonal basal ring; the bars are distinctly convex. Hexagonal variants are common (f. hexalitha), but one heptagonal skeleton (f. heptalitha) was also found in the present material. The question mark after the genus name should indicate some questions about the phylogenetic origin of this species, which may have developed from Distephanus, in contrast to all other Mesocena species, which are regarded as derivates of Dictyocha.

\section{Mesocena? hexalitha f. heptalitha $\mathrm{n} . \mathrm{f}$.}

(Plate 8, Fig. 6)

Holotype. SM.B 13511; Plate 8, Fig. 6.

Type locality. Lord Howe Rise, DSDP 591-30,CC (upper Miocene).

Description. Basal ring heptagonal, the bars distinctly convex, with 7 short radial spines. Diameter $62 \mu \mathrm{m}$.

Remarks. The new form might be confused with specimens described by Schulz (1928) as Mesocena polymorpha f. septenaria, but the latter has distinctly straight basal bars.

\section{Mesocena? hexalitha Bukry f. hexalitha}

(Plate 8, Fig. 5)

\section{Mesocena occidentalis Hanna ex Mandra}

(not figured)

1931 Mesocena occidentalis Hanna, Calif. Div. Mines Dept., State Mineral., 27(2):200, plate E, fig. 1 (invalid).

1968 Mesocena occidentalis Hanna ex Mandra, Proc. Calif. Acad. Sci., $36(9): 260$, figs. $29,32,33$.

Remarks. Robust quadrate ring, with distinct spine at each corner. Present in low numbers in all middle Eocene samples at Site 588 ( $\mathrm{Na}$ viculopsis foliacea Zone).

\section{Mesocena quadrangula Ehrenberg ex Haeckel}

(Plate 8, Figs. 1, 2; Plate 12, Figs. 6, 7)

1873 Mesocena quadrangula Ehrenberg, Abh. Akad. Wiss. Berlin, 1872:145, 273 (nomen nudum).

1887 Mesocena quadrangula Ehrenberg ex Haeckel, Rep. Sci. Res. Voy. Challenger, 18:1556.

Remarks. This species usually has a tetragonal basal ring. Basal bars may vary from straight to rounded or slightly waved. The radial spines are rather long.

\section{Genus NAVICULOPSIS Frenguelli, 1940}

Type species. Naviculopsis biapiculata (Lemmermann, 1901) Frenguelli, 1940, ex Dictyocha navicula var. biapiculata Lemmermann, 1901.

Description. Skeleton consisting of a basal ring and an apical apparatus. Basal ring digonal or elliptical, with 2 radial spines, or spines absent; generally without basal pikes. Apical apparatus usually barlike or bandlike, but sometimes also composed of short struts and an apical bar, seldom bearing an apical pike.

Remarks. No generic differentiation is made here between species supporting radial spines and those without them, because the latter are clearly derived from the spiny forms.

\section{Naviculopsis biapiculata (Lemmermann) Frenguelli (not figured)}

1901 Dictyocha navicula var. biapiculata Lemmermann, Ber. D. Bot. Ges., 19:258, plate 10, figs. 14, 15 .

1940 Naviculopsis biapiculata (Lemmermann) in Frenguelli, Rev. Mus. La Plata, 2 (Pal. 7):60, text-figs. 11 c-d.

1975 Naviculopsis biapiculata (Lemmermann) in Perch-Nielsen, Init. Repts. DSDP, 29:689, plate 12, figs. 18-22.

Remarks. Navicular skeleton with two long spines along the main axis and a small apical bridge. The basal ring is slightly concave at the connecting points of the apical bridge. Rare or few specimens are present in all middle Eocene samples at Site 588, but the species is also found reworked throughout the middle Miocene to upper Pliocene sequence at Site 594.

\section{Naviculopsis foliacea Deflandre (not figured)}

1950 Naviculopsis foliacea Deflandre, Microscopie, 2:204, text-figs. 235-240.

1960 Naviculopsis foliacea Deflandre in Martini and Müller, Init. Repts. DSDP, 38:837, plate 12, fig. 4.

Remarks. This slender navicular species is present in all middle Eocene samples at Hole 588C (Naviculopsis foliacea Zone).

\section{Genus NEONAVICULOPSIS n. gen.}

Type species. Neonaviculopsis neonautica (Bukry, 1981) n. comb. ex Dictyocha neonautica Bukry, 1981.

Description. Skeleton consisting of a basal ring and an apical apparatus. Basal ring digonal with two radial spines, but basal pikes are absent. Apical apparatus usually constructed of a simple bar (naviculopsoid morphes), but sometimes also composed of struts and an apical bar (dictyochid morphes). Differentiation from Naviculopsis is based mainly on the stratigraphic ranges of the two genera rather than on morphological features.

Remarks. The new genus includes a special group of naviculopsoid taxa which developed in the late Miocene from the Dictyocha fibula group. These naviculopsoid taxa, all placed in Neonaviculopsis neo- 
nautica, reflect the typical habitus of Naviculopsis, a genus known from the early Paleocene to the early Micocene. Because the development of the neonautica group marks a second radiation of naviculopsoid taxa, a new genus was introduced.

The taxa united in Neonaviculopsis most probably indicate a unique evolutionary line. Therefore, the different members are treated only as subspecies and forms of one species. It seems especially remarkable that in younger populations 2 different morphes are present, one reflecting its derivation from Dictyocha and the other one an evolved stage of Neonaviculopsis.

\section{Neonaviculopsis neonautica (Bukry) n. comb.}

Remarks. Neonaviculopsis neonautica is characterized by an elongated basal ring bearing 2 short radial spines and an apical apparatus, usually bar-shaped. The subspecies may be distinguished by the proportions of the skeleton, the forms by the structure of the apical apparatus.

\section{Neonaviculopsis neonautica (Bukry) ssp. neonautica}

1981 Dictyocha neonautica Bukry, Spec. Publ. Soc. Econ. Paleontol. Mineral., 32:442.

Remarks. This subspecies has a strikingly slender basal ring, more than twice as long as it is wide. Besides f. neonautica, specimens of $f$. praenautica supporting a dictyochid apical apparatus were found.

Neonaviculopsis neonautica (Bukry) ssp. neonautica f. neonautica (Plate 10, Figs. 6-11)

\author{
Neonaviculopsis neonautica (Bukry) ssp. neonautica f. praenautica \\ (nm) \\ (Plate 10, Fig. 12)
}

Neonaviculopsis neonautica ssp. praenautica n. ssp.

(Plate 10, Figs. 1-5)

Holotype. SM.B 13512; Plate 10, Fig. 5.

Type locality. Lord Howe Rise, DSDP 591-29,CC (upper Miocene).

Description. Basal ring oval with 2 radial spines aligned with the long axis. Apical apparatus composed of a long apical bar and 4 struts. Length 44 to $55 \mu \mathrm{m}$.

Remarks. This new subspecies resembles in outline some specimens of Dictyocha fibula, indicating close evolutionary relations, but the radial spines along the short axis are generally missing. The apical apparatus consists of a large bar which nearly reaches the basal ring. In the material investigated only the typical $f$. praenautica could be found.

\section{Genus PARAMESOCENA n. gen.}

Type species. Paramesocena apiculata (Lemmermann, 1901) n. comb, ex Mesocena circulus var. apiculata Lemmermann, 1901.

Typification. The new genus is erected here to solve the many questions related to discrimination of the mesocenoid apiculata-circulus group from the genus Distephanus. As several authors have indicated, this species group represents a special evolutionary line which certainly originates from the $D$. polyactis group (Frenguelli, 1940; Ling, 1972; Dumitrică, 1973b; Perch-Nielsen, 1975). If the ancestor is included in a separate genus covering this line, Paradictyocha Frenguelli, 1940, can be employed. But if one maintains the opinion that $D$. polyactis still belongs to Distephanus, another genus must be used, because $D$. polyactis has clearly been indicated as type of the genus Paradictyocha (Frenguelli, 1940). According to article 48.1 of the ICBN, it is not permitted to designate a new type species for Paradictyocha as Dumitrică (1973b) did solely to preserve the genus name. Because no genus was available to comprise this group, the new genus was introduced.

Description. Skeleton consisting only of a basal ring, which is wide, polygonal, or circular, with numerous radial spines or nodes; basal pikes are generally absent. Distinguished from Mesocena and Septamesocena by the high number of radial spines displayed in all species.

Paramesocena apiculata (Lemmermann) n. comb.

$$
\text { (Plate 9, Figs. 1, 5; Plate 12, Fig. 3) }
$$

1901 Mesocena circulus var. apiculata Lemmermann, Ber, D. Bot. Ges., 19:257, plate 10, figs. 9, 10.
1940 Paradictyocha apiculata (Lemmermann) in Frenguelli, Rev. Mus. La Plata, 2(Pal. 7):52 plate 4, fig. 4.

Remarks. This species shows a basal ring with many short spines, arranged in 2 slightly diverging rows.

Paramesocena circulus (Ehrenberg) n. comb.

(Plate 9, Figs. 2-4; Plate 12, Figs. 4, 5)

1841 Dictyocha (Mesocena) circulus Ehrenberg, Ber. Akad. Wiss. Berlin, 1840:208.

1845 Mesocena circulus Ehrenberg in Ehrenberg, Ber. Akad. Wiss. Berlin, 1844:65.

1854 Mesocena circulus Ehrenberg in Ehrenberg, Mikrogeologie, plate 19 , fig. 44.

1974 Bachmannocena circulus (Ehrenberg) in Locker, Eclog. Geol. Helv., 67:636, plate 2, fig. 11 (=lectotype).

Remarks. This species possesses a basal ring with many small, sometimes nodular spines, arranged at varying distances from another, but generally in one plane.

\section{Paramesocena dumitricae (Perch-Nielsen) n. comb.}

(Plate 9, Fig. 7)

1975 Paradictyocha dumitricae Perch-Nielsen, Init. Repts. DSDP, 29: 689 , plate 11 , figs. $1,5-8$.

Remarks. The species has a basal ring with many spines that are usually larger than in other species of the genus and that are arranged farther from each other.

\section{Genus SEPTAMESOCENA Bachmann, 1970}

Type species. Septamesocena apiculata (Schulz, 1928) Bachmann, 1970, ex Mesocena oamaruensis var, apiculata Schulz, 1928.

Description. Skeleton consisting only of a basal ring that is trigonal or tetragonal, usually with radial spines but also without spines, and often bearing septate corners; basal pikes generally absent.

Remarks. According to Bachmann (1970) the genus Septamesocena is regarded as derived from Corbisema. Therefore, the species are most frequently furnished with 3 radial spines; but besides the trigonal main morphes tetragonal forms may also be developed in the populations. The septate corners present in some species clearly indicate phylogenetic relations to Corbisema.

\section{Septamesocena apiculata (Schulz) Bachmann (not figured)}

1928 Mesocena oamaruensis var. apiculata Schulz, Bot. Arch., 21: 240 , text-fig. 11.

1931 Mesocena apiculata (Schulz) in Hanna, State Mineral., 27:198, plate D, fig. 3 .

1970 Septamesocena apiculata (Schulz) in Bachmann, Cat. Foss. Austria, 1b:13-14.

Remarks. The triangular specimens vary in shape from distinctly angular to rounded. Radial spines are usually short. In several cases septa are visible. The species occurs reworked in several Miocene samples at Site 594

\section{Class CHRYSOPHYCEAE Order CHRYSOMONADALES Family SYNURACEAE Genus MACRORA Hanna, 1932}

1932 Macrora Hanna, Proc. Calif. Acad. Sci., ser. 4, 20:196. 1938 Pseudorocella Deflandre, Bull. Soc. Fr. Microsc., 7:91.

Type species. Macrora stella (Azpeitia, 1911) Hanna, 1932, ex Pyxidicula? stella Azpeitia, 1911 (syn. Pseudorocella corona Deflandre, 1947).

\section{Macrora stella (Azpeitia) Hanna \\ (Plate 7, Fig. 13; Plate 12, Figs. 8, 9)}

1911 Pyxidicula? stella Azpeitia, Ass. Esp. Progr. Cien. Congr. Zaragoza, $4: 150$, plate 1 , fig. 1 .

1932 Macrora stella (Azpeitia) in Hanna, Proc. Calif. Acad. Sci., ser. 4, 20:196, plate 12 , fig. 7 .

1947 Pseudorocella corona Deflandre, Bull. Soc. Bot. Fr., 93:337, text-fig. 4. 
Remarks. The platelike elements, appearing slightly serrate in outline, are penetrated by several openings varying in number and size. The center of each plate is occupied by a domeshaped elevation. Present in the middle Miocene (Corbisema triacantha Zone) of Site 591.

\section{SPONGE SPICULES}

Sponge spicules are present throughout the Neogene of Sites 591 and 594, probably indicating that the water depth in both areas was relatively shallow during Neogene time. From base to top of the sections the sponge spicules change slightly in number and type, and a detailed investigation is intended. Some sponge spicules are figured on Plate 13. For terminology and some general remarks the reader is referred to papers by Rauff (1893/94), Bukry (1978b) and Martini (1981).

The most common types found in both sequences are amphioxes (Plate 13, figs. 1, 12, 13). But besides these simple forms there are present some very complicated types which may be significant for defining time intervals. For example, a special tetractin with branched terminations (Plate 13, Fig. 7) seems to be characteristic of the early Pliocene.

\section{ACKNOWLEDGMENTS}

Thanks are due to the Deutsche Forschungsgemeinschaft (Bonn) for supporting the present study. The Geologisch-Paläontologisches Institut der Universität Kiel provided space for laboratory work (S.L.). SEM pictures were taken by J. Tochtenhagen with a Stereoscan Mark 2, which was made available to the Geologisch-Paläontologisches Institut der Universität Frankfurt am Main by the Volkswagenstiftung. Our thanks go also to Dr. Amanda Palmer (Texas A\&M University) and Dr. Cynthia Shaw (Exxon, U.S.A., Houston) for reviewing this paper.

The type specimens of the new taxa are deposited in the Naturmuseum und Forschungsinstitut Senckenberg, Frankfurt am Main, Federal Republic of Germany, Catalog Nos. SM.B 13508 to 13512.

\section{REFERENCES}

Bachmann, A., 1970. Flagellata (Silicoflagellata). In Zapfe, H. (Ed.), Catalogus Fossilium Austriae.

1971. Silicoflagellaten aus dem oberen Badenien von Walbersdorf, Burgenland. Sitz.-Ber. Österr. Akad. Wiss., Math.-Nat. Kl., 179:55-72.

Bukry, D., 1973. Coccolith and silicoflagellate stratigraphy, Deep Sea Drilling Project, Leg 18, eastern North Pacific. In Klum, L. D., von Huene, R., et al., Init. Repts. DSDP, 18: Washington (U.S. Govt. Printing Office), 817-831.

1974. Stratigraphic value of silicoflagellates in nontropical regions. Geol. Soc. Am. Bull., 85:1905-1906.

1975. Silicoflagellate and coccolith stratigraphy, Deep Sea Drilling Project, Leg 29. In Kennett, J. P., Houtz, R. E., et al., Init. Repts. DSDP, 29: Washington (U.S. Govt. Printing Office), 845-872.

,1976a. Cenozoic silicoflagellate and coccolith stratigraphy, South Atlantic Ocean, Deep Sea Drilling Project, Leg 36. In Hollister, C. D., Craddock, C., et al., Init. Repts. DSDP, 35: Washington (U.S. Govt. Printing Office), 885-917.

1976b. Silicoflagellate and coccolith stratigraphy, southeastern Pacific Ocean, Deep Sea Drilling Project Leg 34. In Yeats, R. S., Hart, S. R., et al., Init. Repts. DSDP, 34: Washington (U.S. Govt. Printing Office), 715-735.

1977. Coccolith and silicoflagellate stratigraphy, central North Atlantic Ocean, Deep Sea Drilling Project Leg 37. In Aumento, F., Melson, W. G., et al., Init. Repts. DSDP, 37: Washington (U.S. Govt. Printing Office), 917-927.

1978a. Cenozoic coccolith and silicoflagellate stratigraphy, offshore Northwest Africa, Deep Sea Drilling Project, Leg 41. In Lancelot, Y., Seibold, E., et al., Init. Repts. DSDP, 41: Washington (U.S. Govt. Printing Office), 689-707.

1978b. Cenozoic coccolith, silicoflagellate, and diatom stratigraphy, Deep Sea Drilling Project, Leg 44. In Benson, W. E., Sheridan, R. E., et al., Init. Repts. DSDP, 44: Washington (U.S. Govt. Printing Office), 807-863.

1978c. Cenozoic silicoflagellate and coccolith stratigraphy, southeastern Atlantic Ocean, Deep Sea Drilling Project, Leg 40. In Bolli, H. M., Ryan, W. B. F., et al., Init. Repts. DSDP, 40: Washington (U.S. Govt. Printing Office), 635-649. 1979a. Coccolith and silicoflagellate stratigraphy, northern Mid-Atlantic Ridge and Reykjanes Ridge, Deep Sea Drilling Project Leg 49. In Luyendyk, B. P., Cann, J. R., et al., Init. Repts. DSDP, 49: Washington (U.S. Govt. Printing Office), 551-581.

1979b. Comments on opal phytoliths and stratigraphy of Neogene silicoflagellates and coccoliths at Deep Sea Drilling Project Site 397 off Northwest Africa. In Luyendyk, B. P., Cann, J. R., et al., Init. Repts. DSDP, 49: Washington (U.S. Govt. Printing Office), $977-1009$.

1980a. Miocene Corbisema triacantha Zone phytoplankton from Deep Sea Drilling Project Sites 415 and 416, off northwest Africa. In Lancelot, Y., Winterer, E. L., et al., Init. Repts. DSDP, 50: Washington (U.S. Govt. Printing Office), 507-523.

$1980 \mathrm{~b}$. Silicoflagellate biostratigraphy and paleoecology in the eastern equatorial Pacific, Deep Sea Drilling Project Leg 54. In Rosendahl, B. R., Hekinian, R., et al., Init. Repts. DSDP, 54: Washington (U.S. Govt. Printing Office), 545-573.

1981a. Silicoflagellate stratigraphy of offshore California and Baja California, Deep Sea Drilling Project Leg 63. In Yeats, R. S., Haq, B. U., et al., Init. Repts. DSDP, 63: Washington (U.S. Govt. Printing Office), 539-557.

1981b. Synthesis of silicoflagellate stratigraphy for Maestrichtian to Quaternary marine sediment. In Warme, I. E., Douglas, R. G., and Winterer, E. L. (Eds.), The Deep Sea Drilling Project: A Decade of Progress. Soc. Econ. Paleont. Mineral., Spec. Publ., 32:433-444.

1982a. Cenozoic silicoflagellates from offshore Guatemala, Deep Sea Drilling Project Site 495. In Aubouin, J., von Huene, R., et al., Init. Repts. DSDP, 67: Washington (U.S. Govt. Printing Office), 425-445.

1982b. Neogene silicoflagellates of the eastern equatorial Pacific, Deep Sea Drilling Project Hole 503A. In Prell, W. L., Gardner, J. V., et al., Init. Repts. DSDP, 68: Washington (U.S. Govt. Printing Office), 311-323.

1983. Upper Cenozoic silicoflagellates from offshore Ecuador, Deep Sea Drilling Project Site 504. In Cann, J. R., Langseth, M. G., Honnorez, J., Von Herzen, R. P., White, S. M., et al., Init. Repts. DSDP, 69: Washington (U.S. Govt. Printing Office), 321342 .

Bukry, D., and Foster, J. H., 1973. Silicoflagellate and diatom stratigraphy, Leg 16, Deep Sea Drilling Project. In van Andel, T. H., Heath, G. R., et al., Init. Repts. DSDP, 16: Washington (U.S. Govt. Printing Office), 815-871.

Burns, R. E., Andrews, J. E., et al., 1973. Site 206. In Burns, R. E., Andrews, J. E., et al., Init. Repts. DSDP, 21: Washington (U.S. Govt. Printing Office), 103-195.

Busen, K. E., and Wise, S. W., Jr., 1977. Silicoflagellate stratigraphy, Deep Sea Drilling Project, Leg 36. In Barker, P. F., Dalziel, I. W. D., et al., Init. Repts. DSDP, 36: Washington (U.S. Govt. Printing Office), 697-743.

Campbell, A. S., 1954. Radiolaria. In Moore, R. C. (Ed.) Treatise on Invertebrate Paleontology, D, 11-163.

Ciesielski, P. F., 1975. Biostratigraphy and paleoecology of Neogene and Oligocene silicoflagellates from cores recovered during Arctic Leg 28, Deep Sea Drilling Project. In Hayes, D. E., Frakes, L. A., et al., Init. Repts. DSDP, 28: Washington (U.S. Govt. Printing Office), 625-691.

Deflandre, G., 1950. Contribution à l'étude des Silicoflagellidés actuels et fossiles. Microscopie, 2:72-108, 117-142, 191-210. 1952. Classe des Silicoflagellidés. In Grassé, P. P. (Ed.), Traité de Zoologie, 1:425-438.

Dumitrică, P., 1973a. Miocene and Quaternary silicoflagellates in sediments from the Mediterranean Sea. In Ryan, W. B. F., Hsü, K. J., et al., Init. Repts. DSDP, 13, Pt. 2: Washington (U.S. Govt. Printing Office), 902-933.

1973b. Paleocene, late Oligocene, and post-Oligocene silicoflagellates in southwestern Pacific sediments cored on DSDP Leg 21. In Burns, R. E., Andrews, J. E., et al., Init. Repts. DSDP, 21: Washington (U.S. Govt. Printing Office), 837-883.

Ehrenberg, C. G., 1838. Über das Massenverhältniss der jetzt lebenden Kiesel-Infusorien und über ein neues Infusorien-Conglomerat als Polirschiefer von Jastraba in Ungarn. Abh. Akad. Wiss. Berlin, 1836, Phys. Abh., pp. 109-135.

1843. Verbreitung und Einfluss des mikroskopischen Lebens in Süd- und Nordamerika. Abh. Akad. Wiss. Berlin, 184l, Phys. Abh., pp. 291-446. 
1854. Mikrogeologie: Das Erden und Felsen schaffende Wirken des unsichtbar kleinen selbstständigen Lebens auf der Erde: Leipzig (Leopold Voss).

Frenguelli, J., 1935. Variaciones de Dictyocha fibula en el Golfo de San Matías (Patagonia Septentrional). An. Mus. Argent. Cienc. Nat., 38, Protist., 4:265-281.

1938. Variaciones de "Dictyocha speculum" Ehr. en el Golfo de San Jorge (Patagonia). Notas Mus. La Plata, 3, Zool., 11: 117-123.

1940. Consideraciones sobre los silicoflagelados fósiles. Rev. Mus. La Plata, 2, Paleont., 7:37-112.

Fuji, N., and Bachmann, A., 1970. Fossile Pollen, Sporen und Silicoflagellaten aus den Hijirikawa-Schichten (Obermiozän) der Halbinsel Noto, Zentral-Japan (III). Silicoflagellaten in den Hijirikawa-Schichten. Bull. Fac. Educ. Kanazawa Univ., 19:77-91.

Gemeinhardt, K., 1934. Die Silicoflagellaten des Südatlantischen Ozeans. Wiss. Erg. D. Atlant. Exp. "Meteor," 1925-1927, 12:274312.

Hajós, M., 1976. Upper Eocene and lower Oligocene diatomaceae, archaemonadaceae, and silicoflagellatae in southwestern Pacific sediments, DSDP Leg 29. In Hollister, C. D., Craddock, C., et al., Init. Repts. DSDP, 35: Washington (U.S. Govt. Printing Office), $817-883$.

Haq, B. U., and Riley, A., 1976. Antarctic silicoflagellates from the Southeast Pacific, Deep Sea Drilling Project Leg 35. In Hollister, C. D., Craddock, C., et al., Init. Repts. DSDP, 35: Washington (U.S. Govt. Printing Office), 673-691.

Hovasse, R., 1932. Contribution à l'étude des silicoflagellés. Multiplication, variabilité, hérédité, affinités. Bull. Biol. Fr. Belg., 66:448501 .

ICBN. See Stafleu (Ed.).

Kraus, O. (Ed.), 1962. Internationale Regeln für die Zoologische Nomenklatur, beschlossen vom XV. Internationalen Kongress für Zoologie: Frankfurt am Main (Senck. Naturf. Ges.).

Ling, H. Y., 1970. Silicoflagellates from central North Pacific core sediments. Bull. Am. Paleont., 58:85-129.

1972. Upper Cretaceous and Cenozoic silicoflagellates and ebridians. Bull. Am. Paleont., 62:135-229.

, 1973. Silicoflagellates and ebridians from Leg 19. In Creager, J. S., Scholl, D. W., et al., Init. Repts. DSDP, 19: Washington (U.S. Govt. Printing Office), 751-775.

1975. Silicoflagellates and ebridians from Leg 31. In Karig, D. E., Ingle, J. C. Jr., et al., Init. Repts. DSDP, 31: Washington (U.S. Govt. Printing Office), 763-777.

1977. Late Cenozoic silicoflagellates and ebridians from the eastern North Pacific Region. Proc. Ist Int. Cong. Pacific Neog. Strat., Tokyo 1976, pp. 205-233.

1980. Silicoflagellates and ebridians from Leg 55. In Jackson, E. D., Koizumi, I., et al., Init. Repts. DSDP, 55: Washington (U.S. Govt. Printing Office), 375-385.

Locker, S., 1974. Revision der Silicoflagellaten aus der Mikrogeologischen Sammlung von C. G. Ehrenberg. Eclog. Geol. Helv., 67:631646.

Loeblich, A. R. III, Loeblich, L. A., Tappan, H., and Loeblich, A. R., Jr., 1968. Annotated Index of Fossil and Recent Silicoflagellates and Ebridians. Geol. Soc. Am. Mem., 106.

Mandra, Y. T., 1969. Silicoflagellates: a new tool for the study of Antarctic tertiary climates. Ant. J. U.S., 4:172-174.

Martini, E., 1971a. Neogene silicoflagellates from the equatorial Pacific. In Winterer, E. L., Riedel, W. R., et al., Init. Repts. DSDP, 7, Pt. 2: Washington (U.S. Govt. Printing Office), 1695-1708. 1971b. Standard Tertiary and Quaternary calcareous nannoplankton zonation. Proc. II Planktonic Conf., Roma 1970, (Vol. 2): Rome (Edizioni: Tecnoscienza), 739-785.

, 1972. Der stratigraphische Wert von Silicoflagellaten im Jungtertiär von Kalifornien und des östlichen Pazifischen Ozeans. Nachr. D. Geol. Ges., 5:47-49.

1976. Neogene and Quaternary silicoflagellates from the central Pacific Ocean (DSDP Leg 33). In Schlanger, S. O., Jackson, E. D., et al., Init. Repts. DSDP, 33: Washington (U.S. Govt. Printing Office), 439-449.

1979. Calcareous nannoplankton and silicoflagellate biostratigraphy at Reykjanes Ridge, northeastern North Atlantic (DSDP Leg 49, Sites 407 and 409). In Luyendyk, B. P., Cann, J. R., et al., Init. Repts. DSDP, 49: Washington (U.S. Govt. Printing Office), 533-549.

1982. Pliocene and Quaternary diatoms, silicoflagellates, sponge spicules, and endoskeletal dinoflagellates from the Philippine Sea, Deep Sea Drilling Project Legs 59 and 60. In Hussong, D. M., Uyeda, S., et al., Init. Repts. DSDP, 60: Washington (U.S. Govt. Printing Office), 565-574.

Martini, E., and Müller, C., 1976. Eocene to Pleistocene silicoflagellates from the Norwegian-Greenland Sea (DSDP Leg 38). In Talwani, M., Udintsev, G., et al., Init. Repts. DSDP, 38: Washington (U.S. Govt. Printing Office), 857-895.

Mayr, E., 1967. Artbegriff und Evolution. Hamburg and Berlin (Paul Parey).

Müller, C., 1981. Miocene to Pleistocene silicoflagellates from the central North Pacific, Deep Sea Drilling Project Leg 62. In Thiede, J., Vallier, T. L., et al., Init. Repts. DSDP, 62: Washington (U.S. Govt. Printing Office), 361-364.

Perch-Nielsen, K., 1975. Late Cretaceous to Pleistocene silicoflagellates from the southern Southwest Pacific, DSDP, Leg 29. In Kennett, J. P., Houtz, R. E., et al., Init. Repts. DSDP, 29: Washington (U.S. Govt. Printing Office), 677-721.

1977. Tertiary silicoflagellates and other siliceous microfossils from the western South Atlantic, Deep Sea Drilling Project Leg 39. In Supko, P. R., Perch-Nielsen, K., et al., Init. Repts. DSDP, 39: Washington (U.S. Govt. Printing Office), 863-867.

Poelchau, H. S., 1976. Distribution of Holocene silicoflagellates in North Pacific sediments. Micropaleontology, 22:164-193.

Rauff, H., 1893/94. Palaeospongiologie: allgemeiner Teil. Palaeontographica, 40:1-232.

Schulz, P., 1928. Beiträge zur Kenntnis fossiler und rezenter Silicoflagellaten. Botan. Archiv., 21:225-292.

Shaw, C. A., and Ciesielski, P. F., 1983. Silicoflagellate biostratigraphy of Middle Eocene to Holocene subantarctic sediments recovered by Deep Sea Drilling Project Leg 71. In Ludwig, W. J., Krasheninnikov, V. A., et al., Init. Repts. DSDP, 71: Washington (U.S. Govt. Printing Office), 687-737.

Stafleu, F. A. (Ed.), 1978. International Code of Botanical Nomenclature, Adopted by the Twelfth International Botanical Congress, Leningrad, July 1975. Utrecht (Bohn, Scheltema and Holkema).

Van Valkenburg, S. D., and Norris, R. E., 1970. The growth and morphology of the silicoflagellate Dictyocha fibula Ehrenberg in culture. J. Phycol., 6:48-54.

Date of Initial Receipt: 19 July 1984

Date of Acceptance: 30 October 1984 


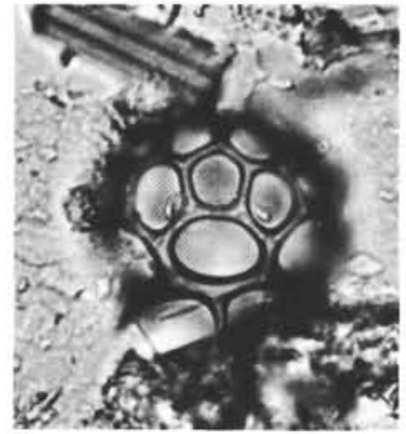

1

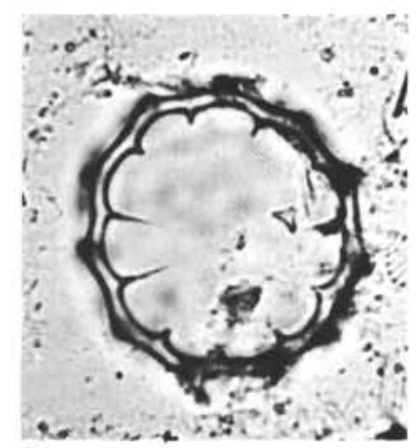

2

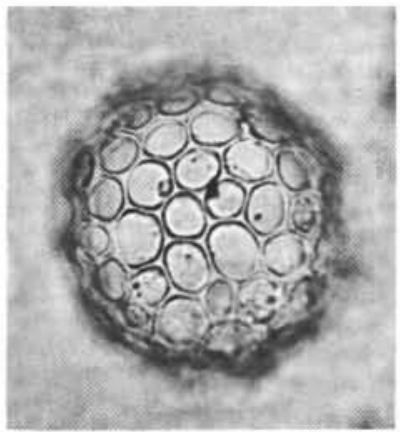

3

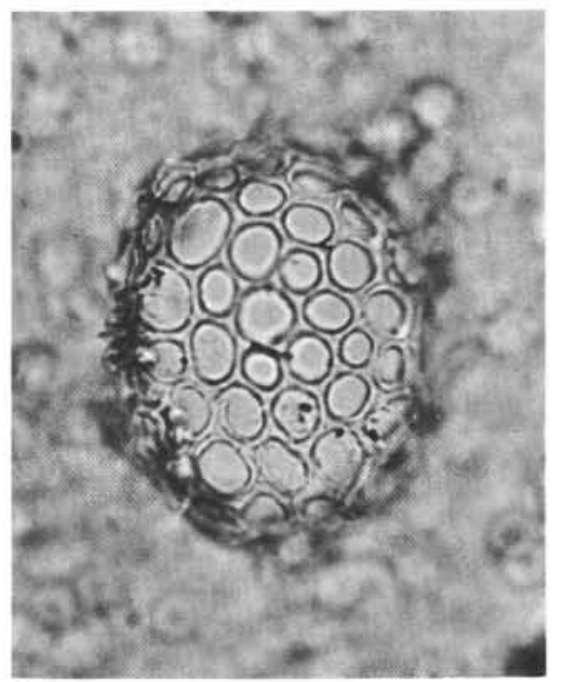

6

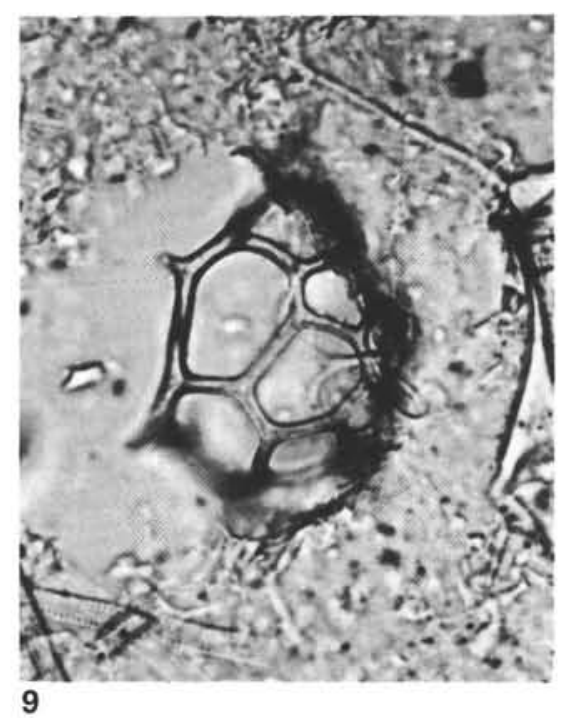

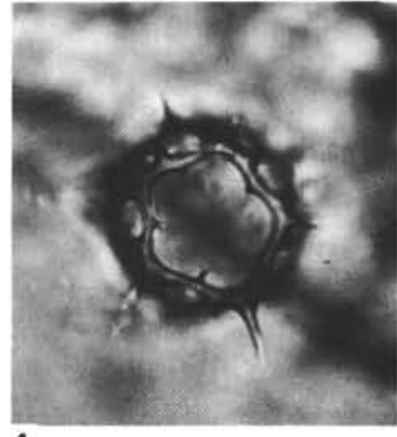

4

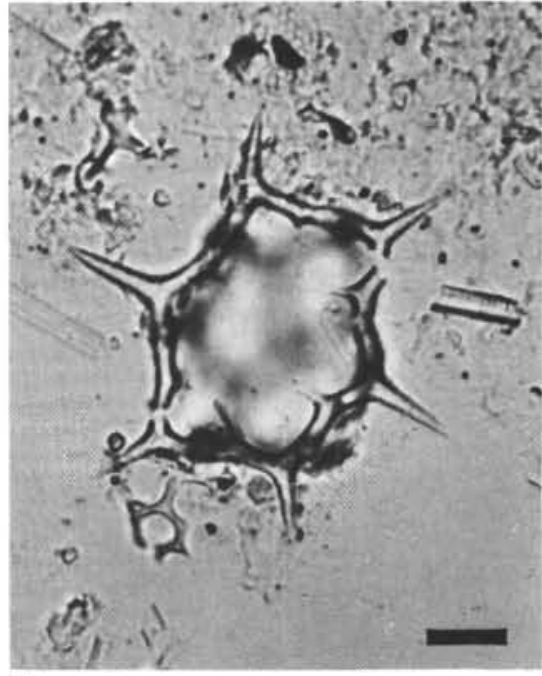

7

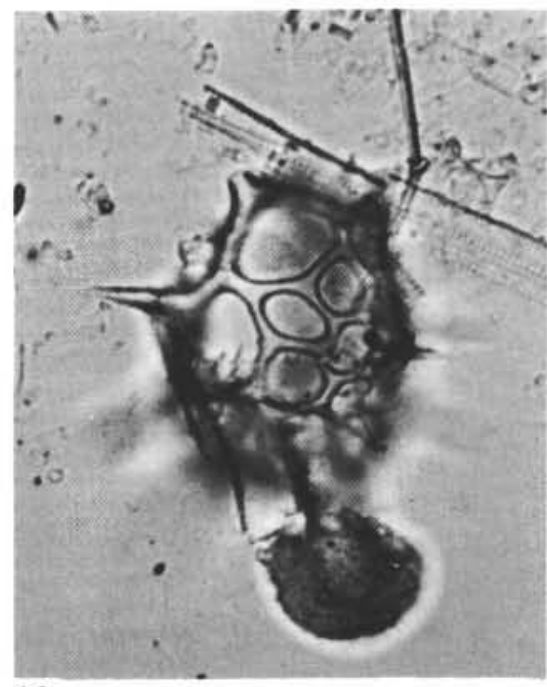

10

Plate 1. Middle Miocene silicoflagellates. (All specimens magnified $\times 800$, bar $=10 \mu \mathrm{m}$.) 1. Cannopilus depressus (Ehrenberg), Sample 59444, CC. 2, 3. Cannopilus ichikawai Bachmann, high and low focus; Sample 591B-18,CC. 4. Cannopilus picassoi Stradner, Sample 591B17,CC. 5, 6. Cannopilus iidaensis Bachmann, high and low focus; Sample 591B-20,CC. 7. Cannopilus hemisphaericus (Ehrenberg), Sample 591B-18,CC. 8. Cannopilus latifenestratus Bachmann, Sample 591B-19,CC. 9. Cannopilus heptacanthus (Ehrenberg) ssp. heptacanthus, Sample 591B-21,CC. 10. Cannopilus heptacanthus ssp. antarcticus (Ciesielski), Sample 591B-16,CC. 


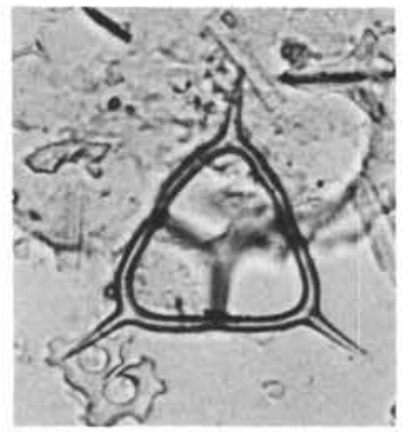

1

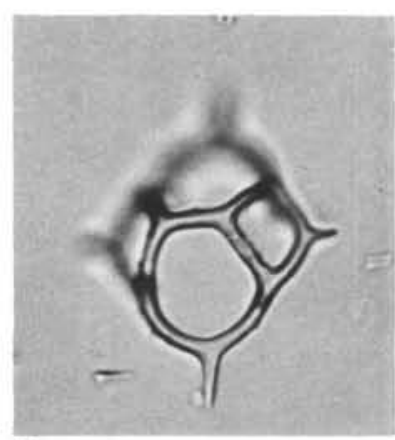

5

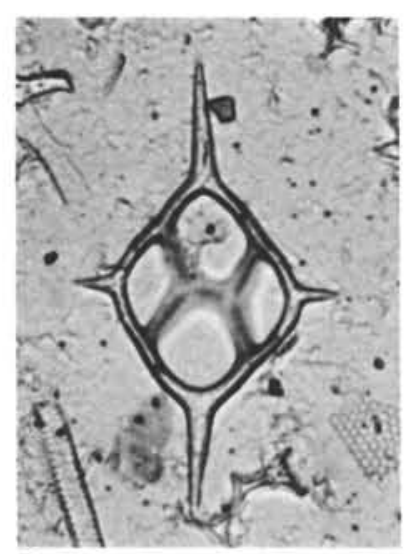

9

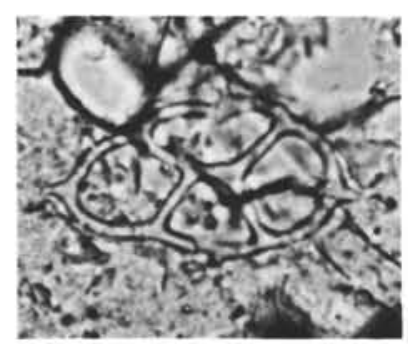

13

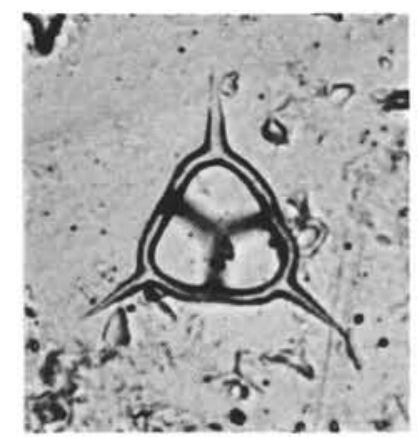

2

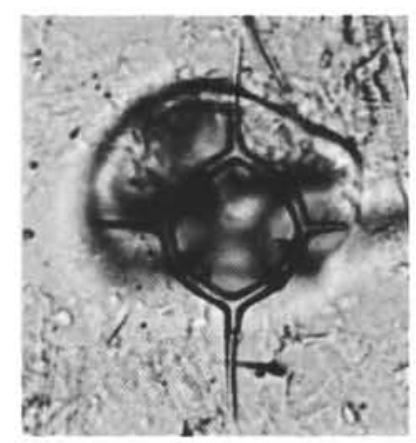

6

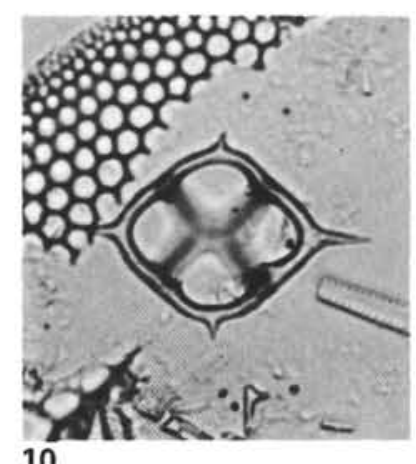

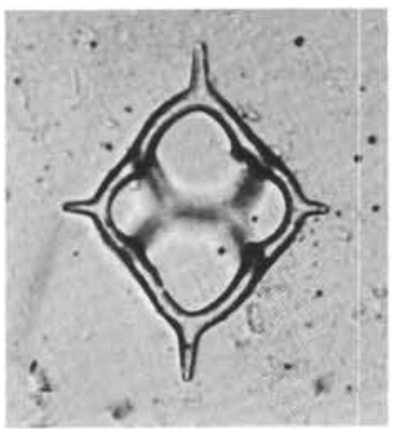

3

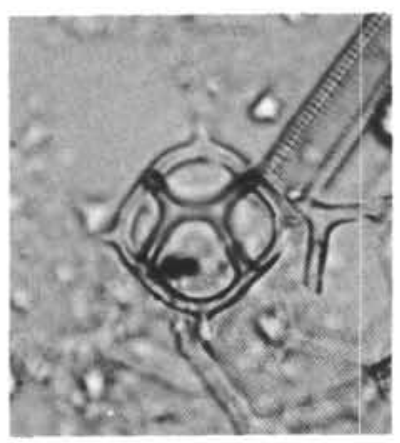

7

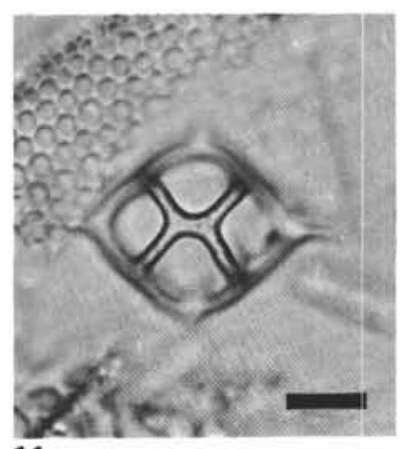

11

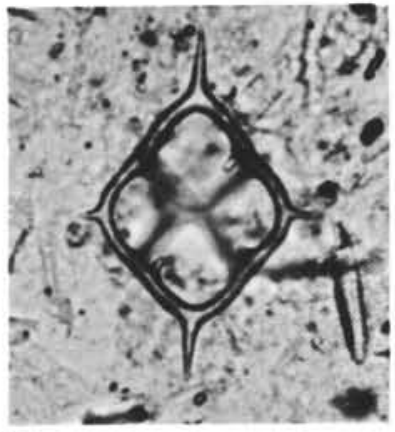

4

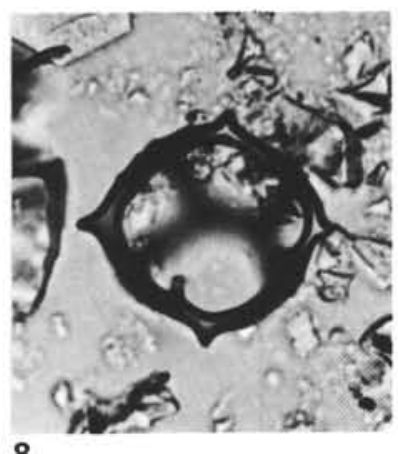

8

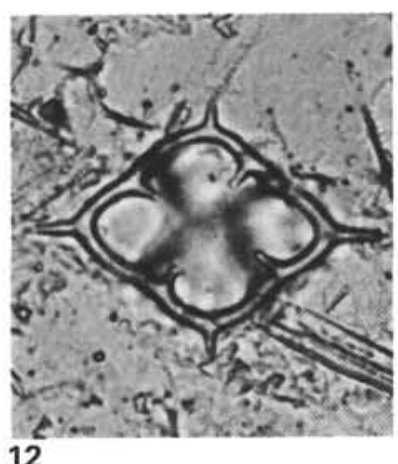

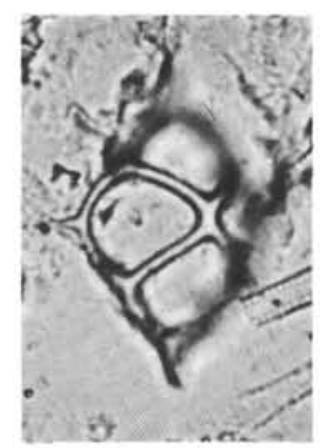

14

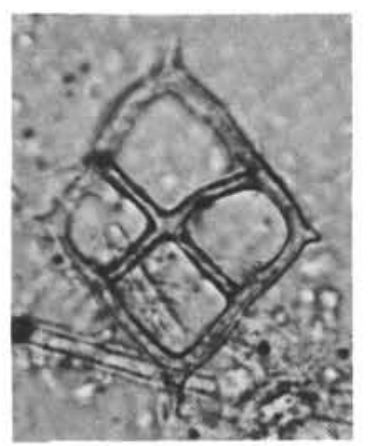

15

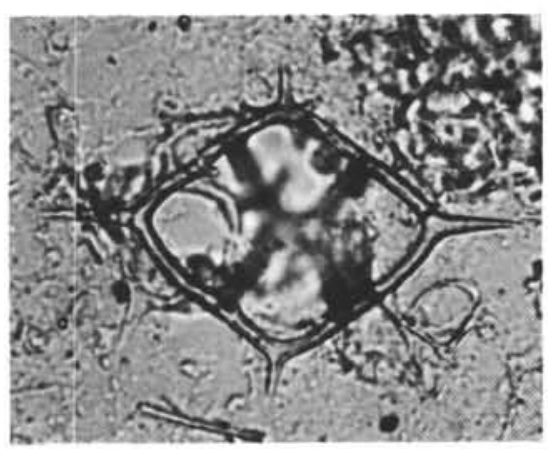

16

Plate 2. Middle Miocene to lower Pliocene silicoflagellates. (All specimens magnified $\times 800$, bar $=10 \mu \mathrm{m}$.) 1, 2. Corbisema triacantha (Ehrenberg), (1) Sample 591B-16,CC, middle Miocene; (2) Sample 591B-20,CC, middle Miocene. 3-5. Dictyocha varia Locker, (3) Sample 59122,CC, lower Pliocene; (4) Sample 591B-6,CC, upper Miocene; (5) Sample 591-19,CC, lower Pliocene. 6. Dictyocha pygmaea (Ciesielski), Sample 591B-16,CC, middle Miocene. 7. Dictyocha sp. 2, Sample 591-20,CC, lower Pliocene. 8. Dictyocha sp. 3, Sample 594-46,CC, middle Miocene. 9. Dictyocha subclinata Bukry, Sample 591B-9,CC, upper Miocene. 10-12. Dictyocha extensa (Locker), (10, 11) high and low focus, Sample 591B-2,CC, upper Miocene; (12) Sample 591B-16,CC, middle Miocene. 13. Dictyocha aegea Stradner and Bachmann, Sample 591B-5,CC, upper Miocene. 14, 15. Dictyocha medusa Haeckel, (14) Sample 591B-17,CC, middle Miocene; (15) Sample 591B-19,CC, middle Miocene. 16. Dictyocha epiodon Ehrenberg, Sample 591B-21,CC, middle Miocene. 


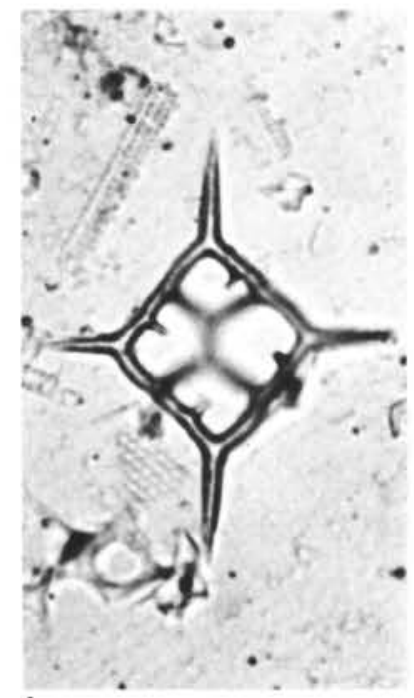

1

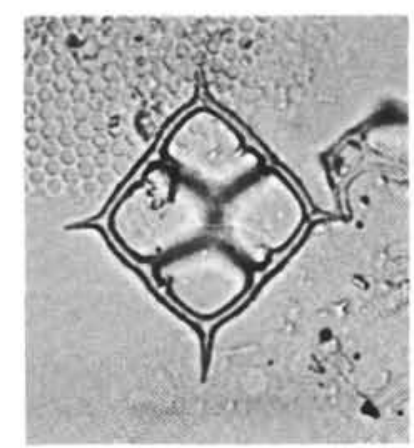

5

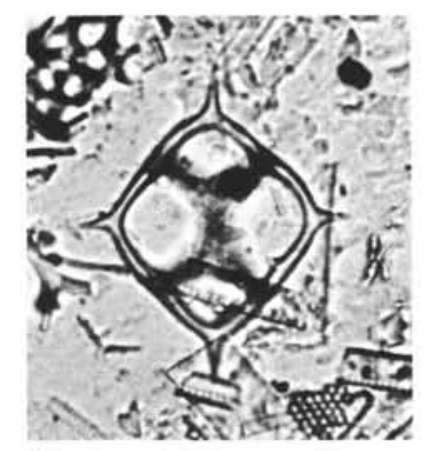

9

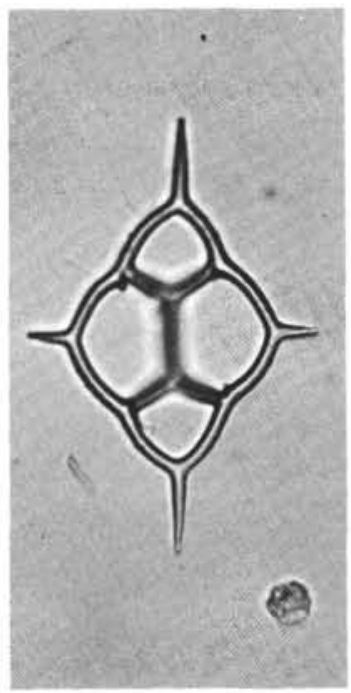

2

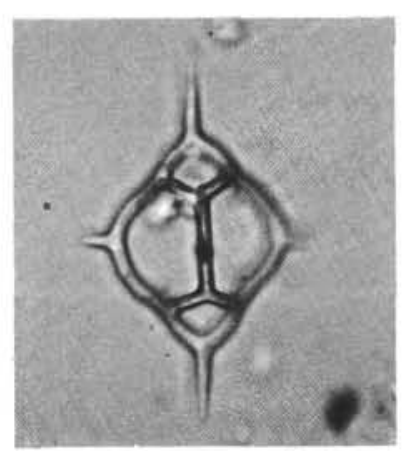

6

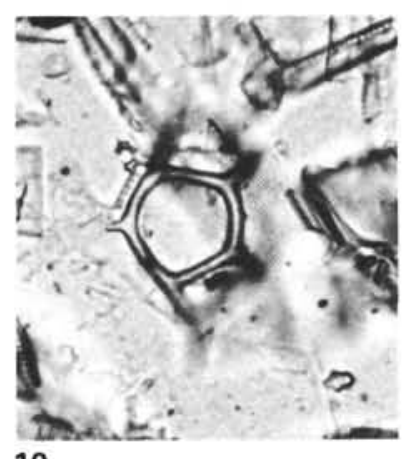

10

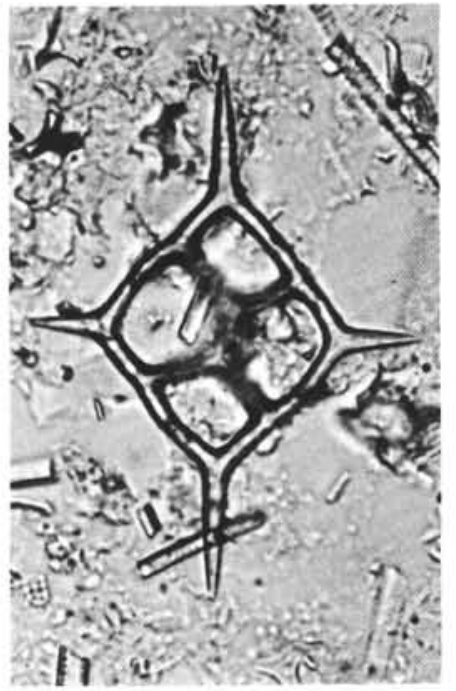

3

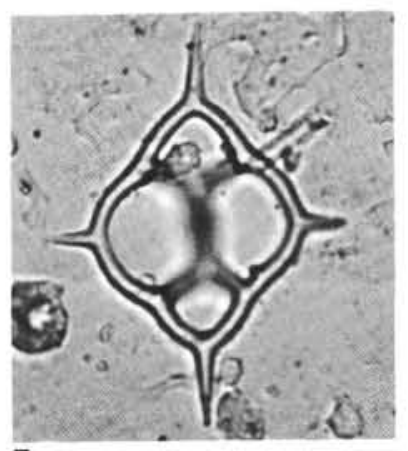

7

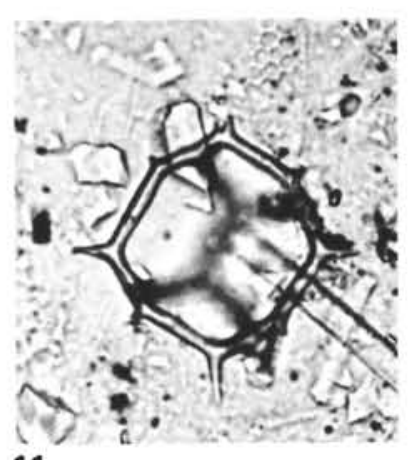

11

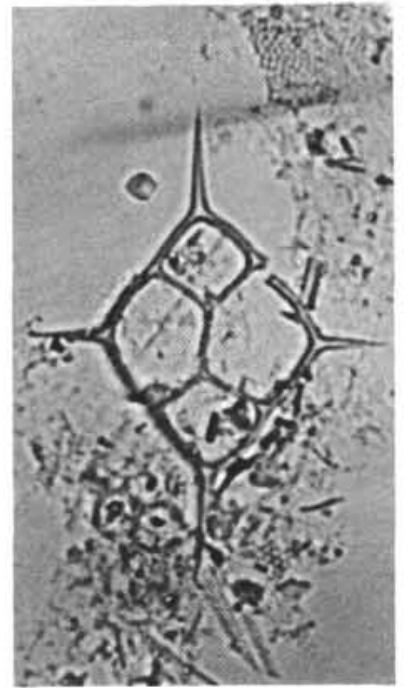

4

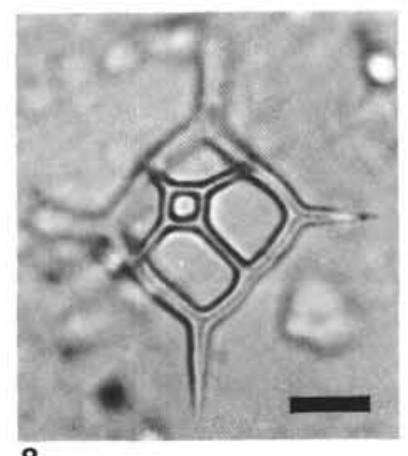

8

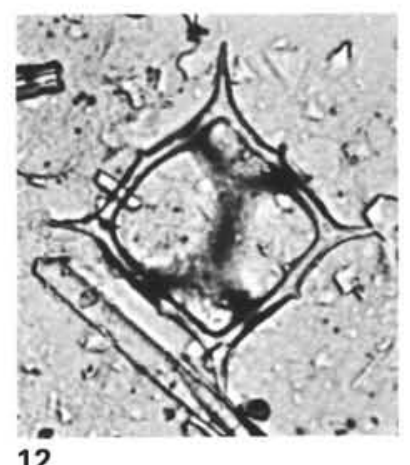

12

Plate 3. Middle Miocene to Quaternary silicoflagellates. (All specimens magnified $\times 800$, bar $=10 \mu \mathrm{m}$.) 1, 9. Dictyocha messanensis Haeckel ssp. messanensis f. aspinosa, (1) Sample 591-26,CC, upper Miocene; (9) Sample 594-16,CC, upper Pliocene. 2. Dictyocha messanensis ssp. stapedia (Haeckel) f. aspinosa, Sample 591-14,CC, lower Pliocene. 3-5. Dictyocha messanensis ssp. aspinosa (Bukry), (3) Sample 594-44,CC, middle Miocene; (4) Sample 591B-7,CC, upper Miocene; (5) Sample 591B-16,CC, middle Miocene. 6, 7. Dictyocha messanensis ssp. stapedia (Haeckel) f. stapedia, (6) Sample 591-14,CC, lower Pliocene, (7) Sample 591-21,CC, lower Pliocene. 8. Dictyocha messanensis ssp. messanensis f. speculum (Frenguelli), Sample 591-27,CC, upper Miocene. 10. Dictyocha messanensis Haeckel ssp. messanensis f. messanensis, Sample 594-16,CC, upper Pliocene. 11, 12. Dictyocha messanensis ssp. aculeata (Lemmermann) f. aculeata, (11) Sample 594-7,CC, Quaternary; (12) Sample 594-9,CC, Quaternary. 


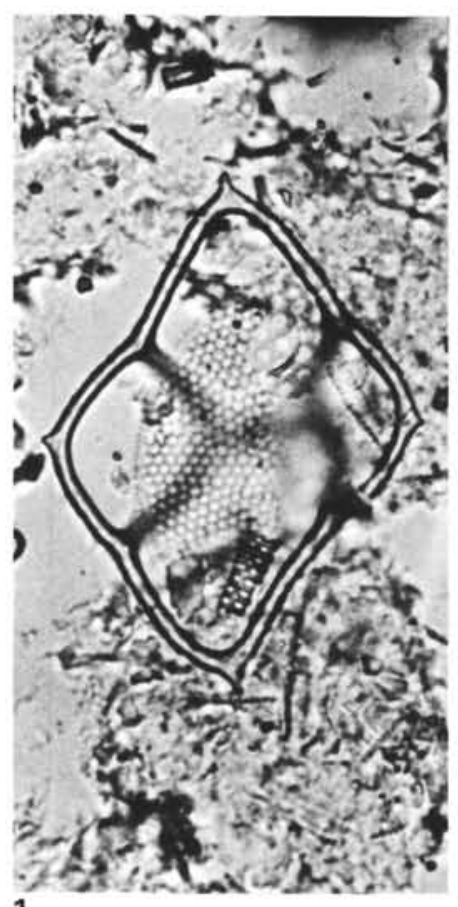

1

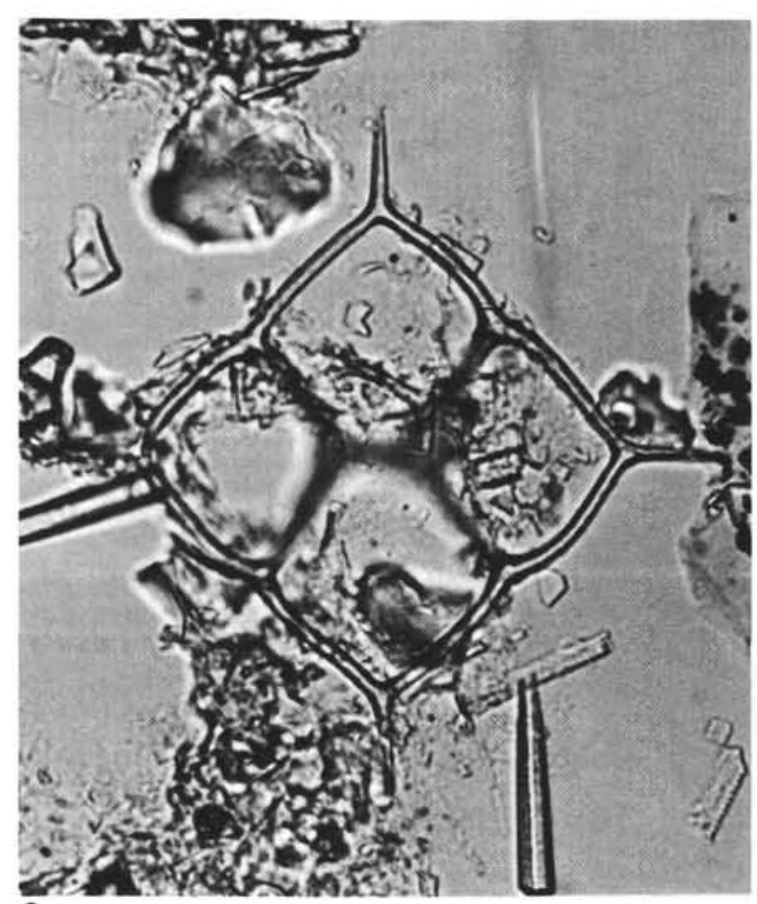

2

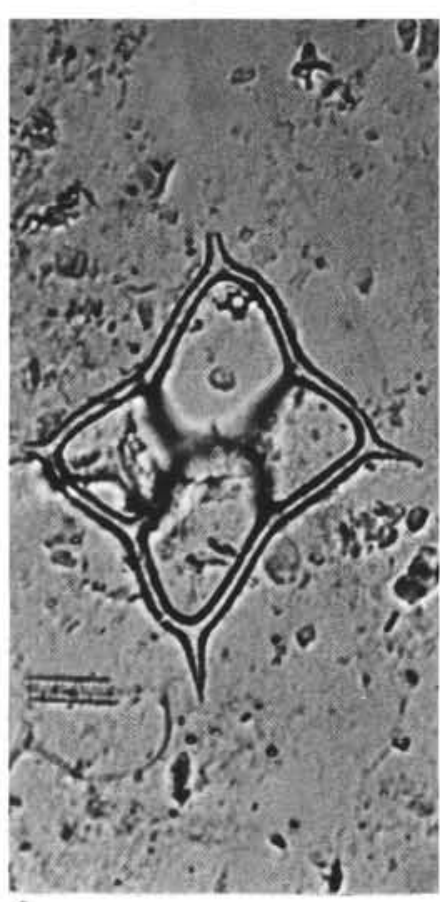

3
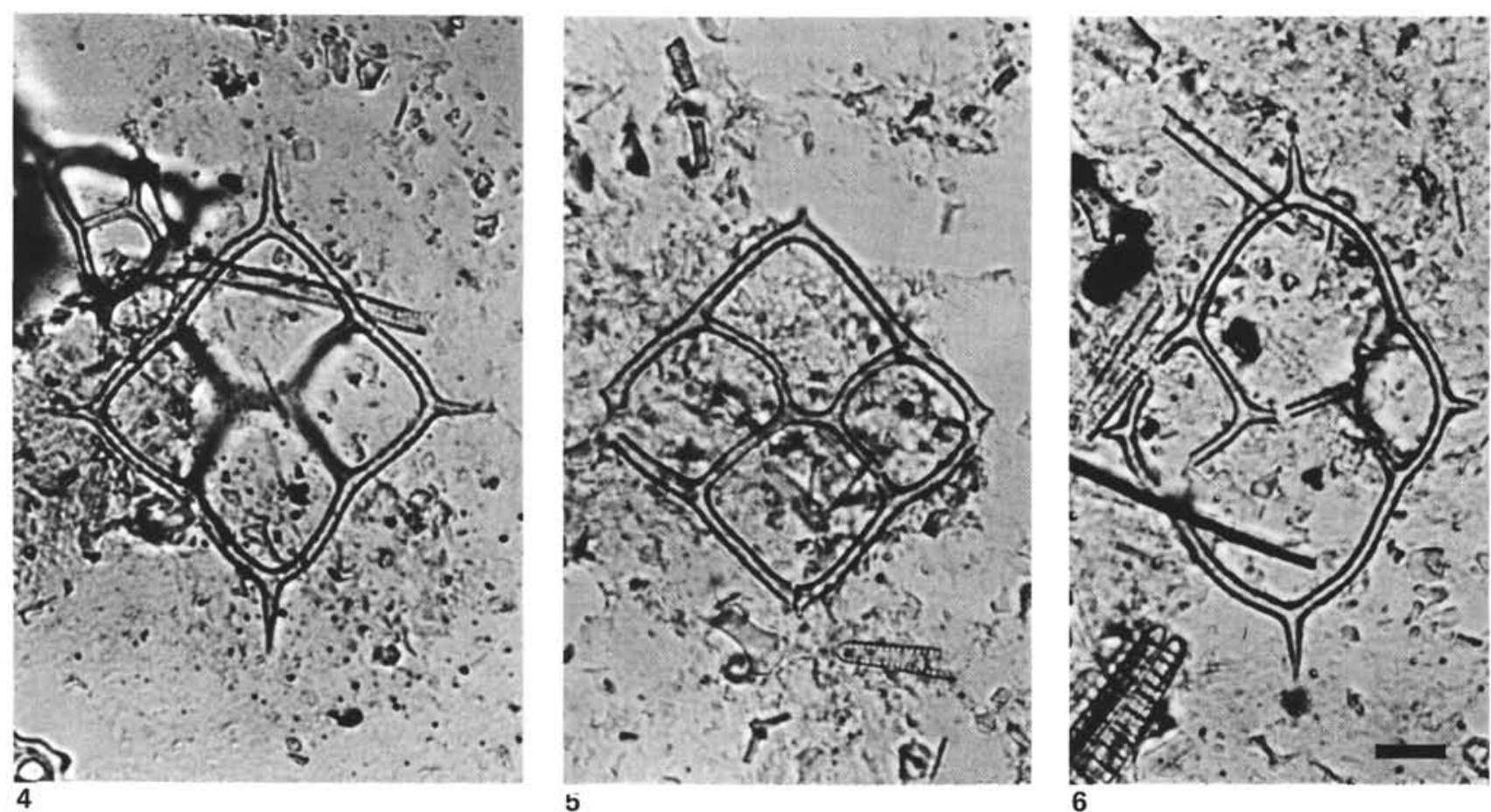

Plate 4. Middle Miocene silicoflagellates. (All specimens magnified $\times 800$, bar $=10 \mu \mathrm{m}$.) 1-6. Dictyocha fibula ssp. asymmetrica n. ssp., (1) holotype SM.B 13508, Sample 591B-21,CC; (2) Sample 594A-12,CC; $(3,4)$ Sample 591B-19,CC; (5) Sample 591B-21,CC; (6) Sample 591B$17, \mathrm{CC}$. 


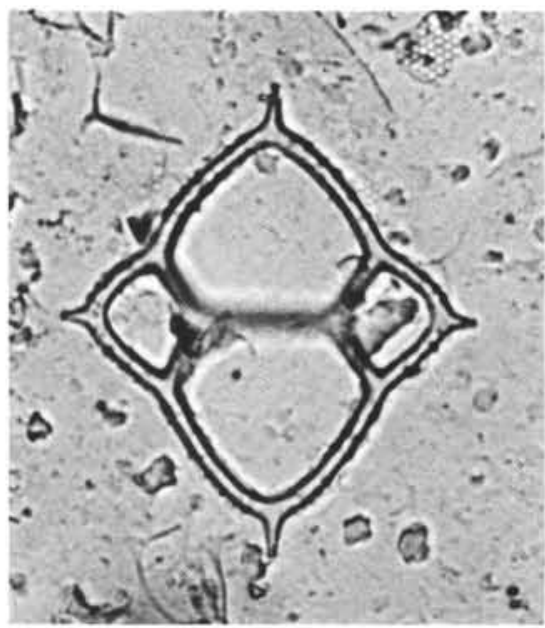

1

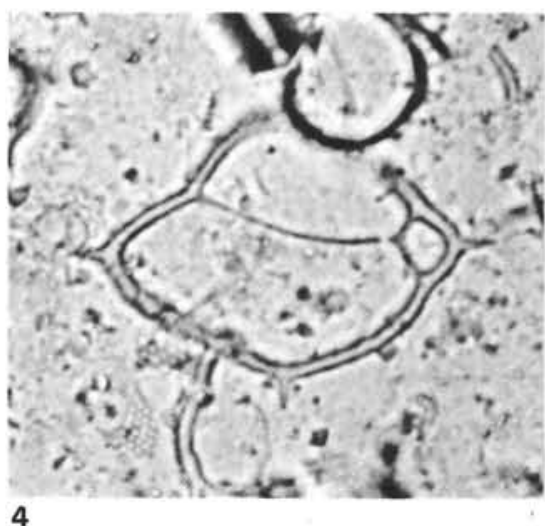

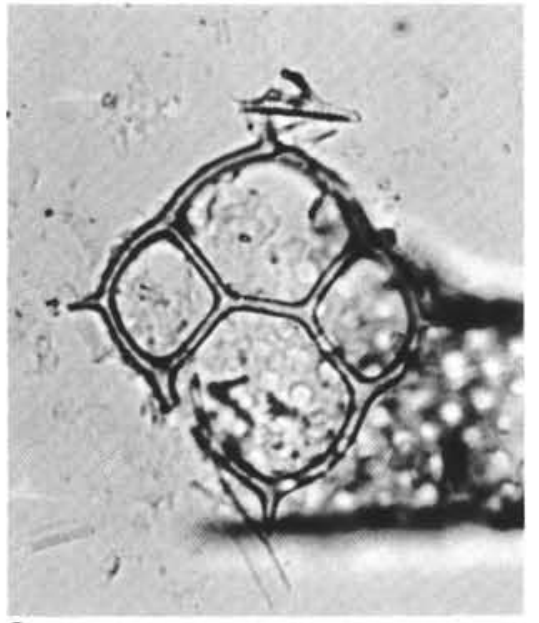

2

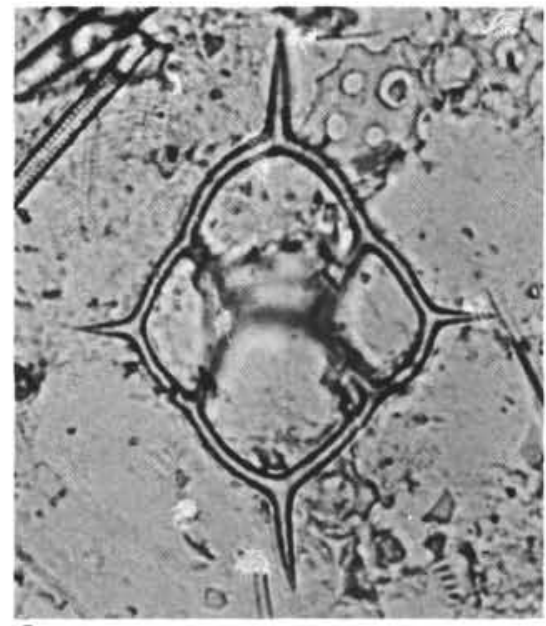

3

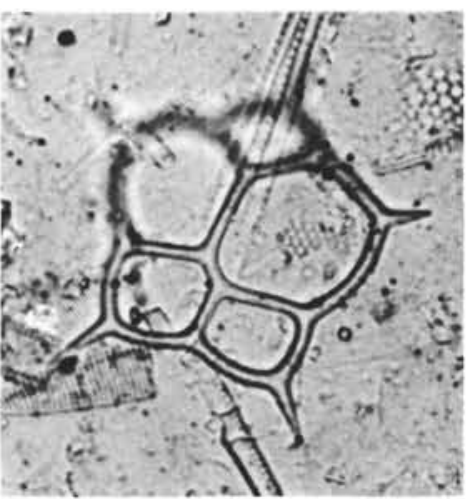

6
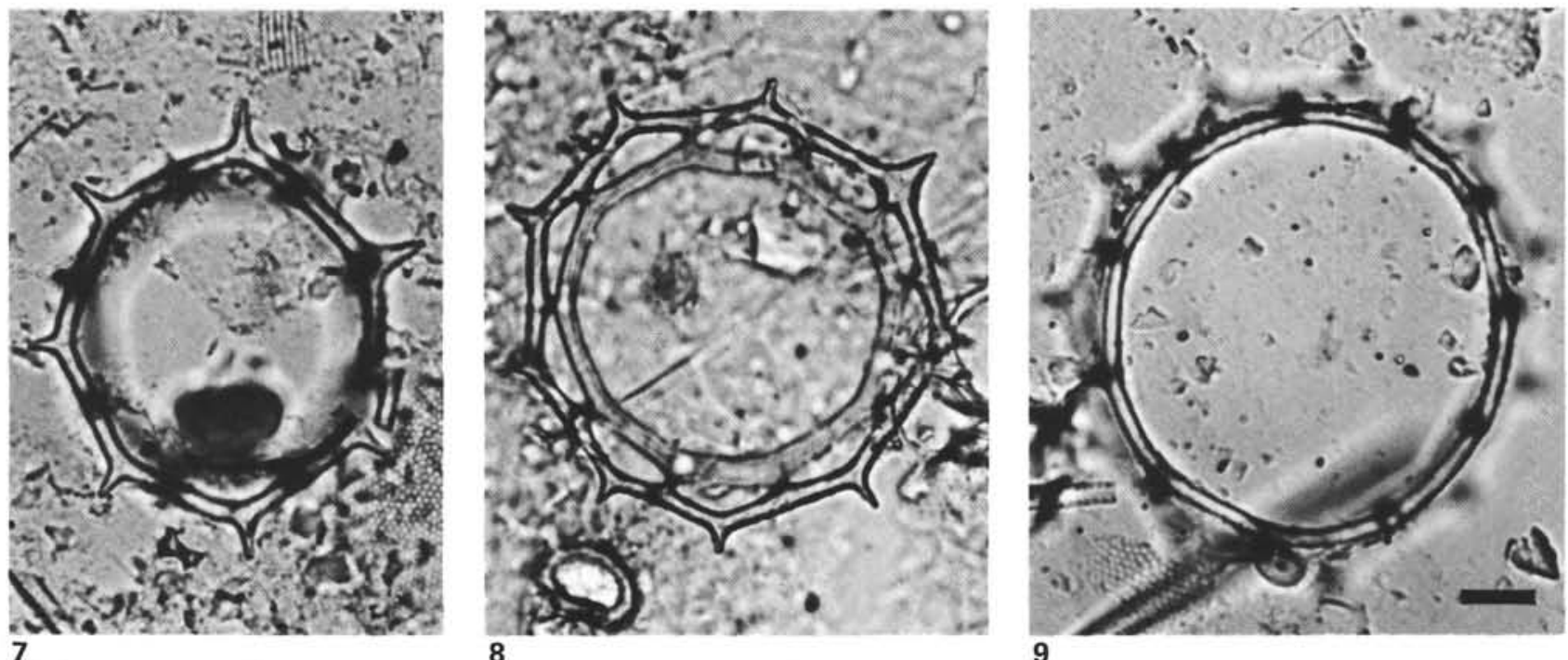

Plate 5. Middle Miocene to lower Pliocene silicoflagellates. (All specimens magnified $\times 800$, bar $=10 \mu \mathrm{m}$.) 1, 2. Dictyocha fibula Ehrenberg ssp. fibula. (1) Sample 591-21,CC, lower Pliocene; (2) Sample 591B-16,CC, middle Miocene. 3. Dictyocha fibula Ehrenberg s. 1., Sample 591B-18,CC, middle Miocene. 4. Dictyocha sp. 1, Sample 591-19,CC, lower Pliocene. 5. Dictyocha perlaevis Frenguelli f. perlaevis, Sample 591-14,CC, lower Pliocene. 6. Dictyocha perlaevis f. pentaradiata n. f., holotype SM.B 13509, Sample 591-20, CC, lower Pliocene. 7. Distephanus polyactis ssp. crassus Bukry, Sample 591B-8,CC, upper Miocene. 8, 9. Distephanus polyactis (Ehrenberg) ssp. polyactis, (8) Sample 591B-4,CC, upper Miocene; (9) Sample 591-21,CC, lower Pliocene. 


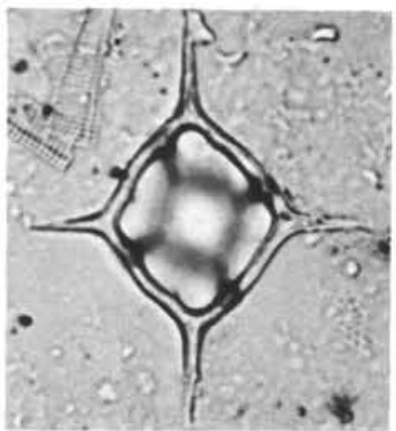

1

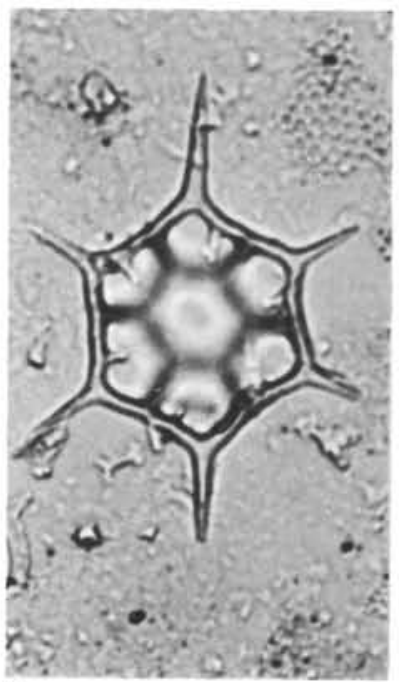

5

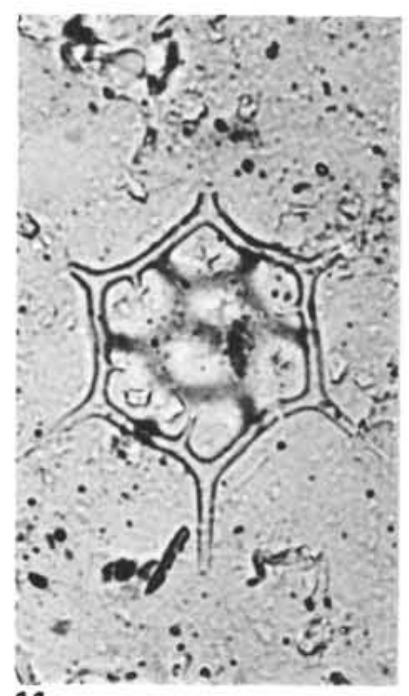

11

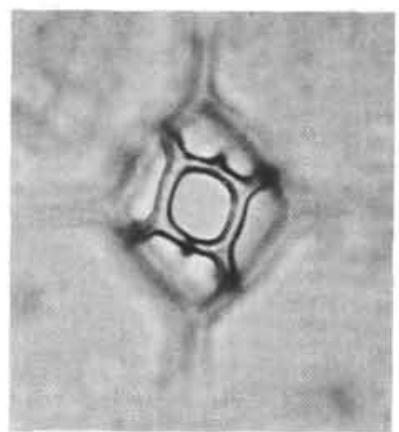

2

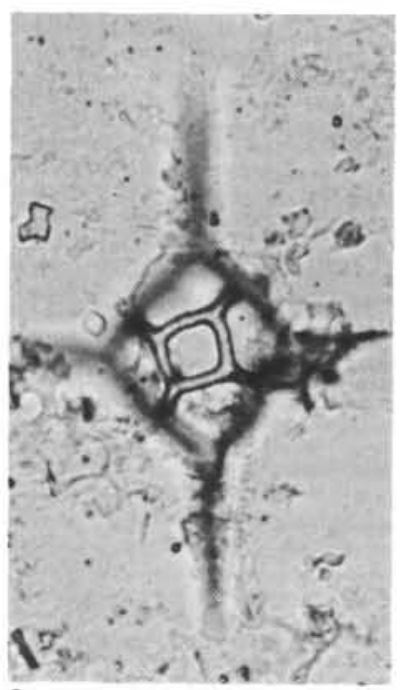

6

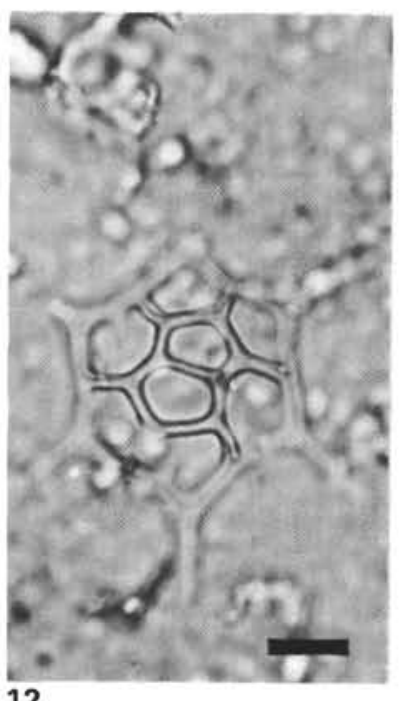

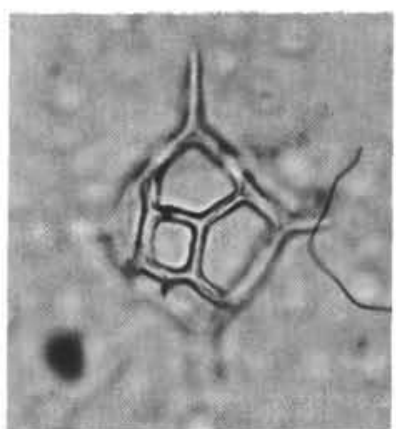

3
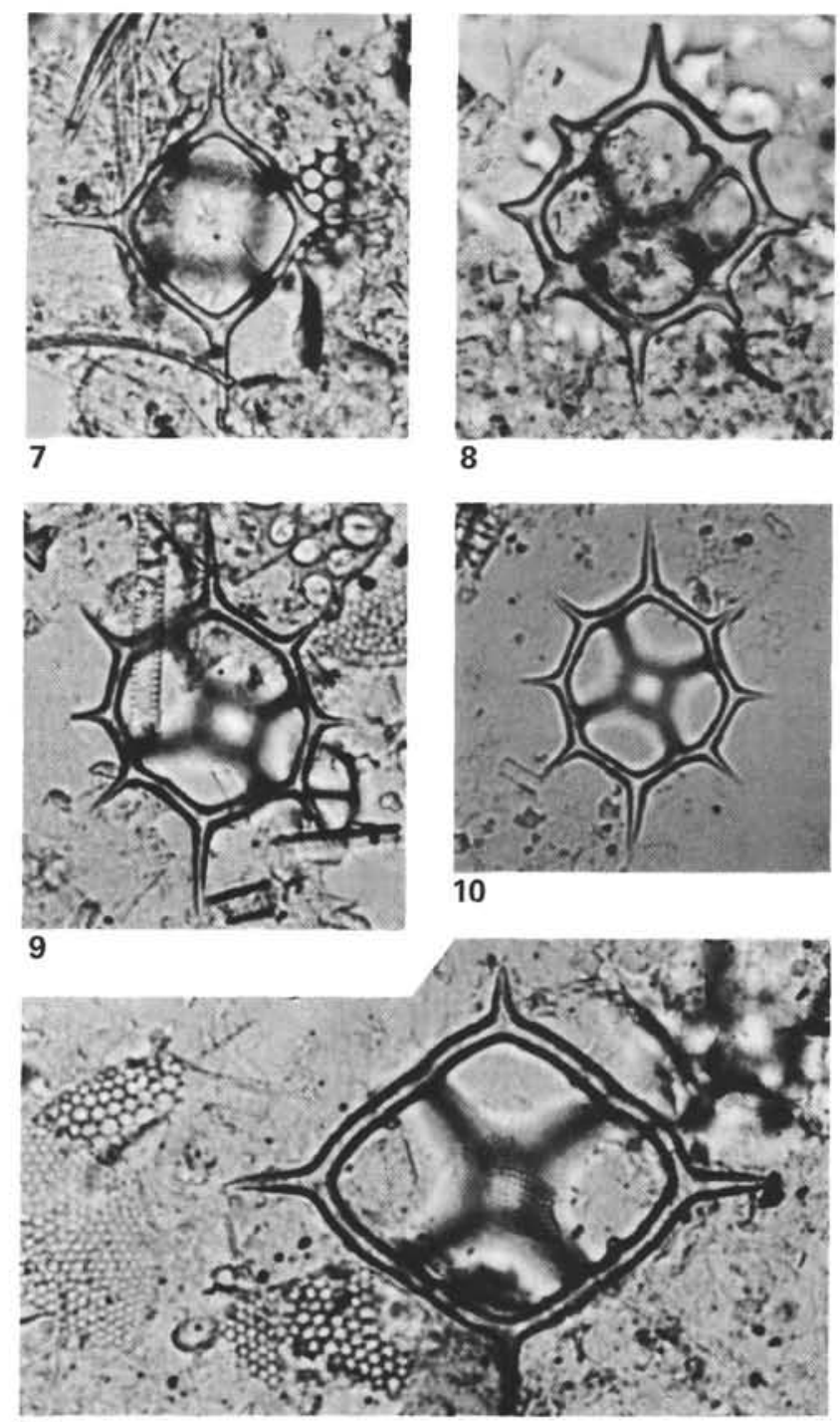

13

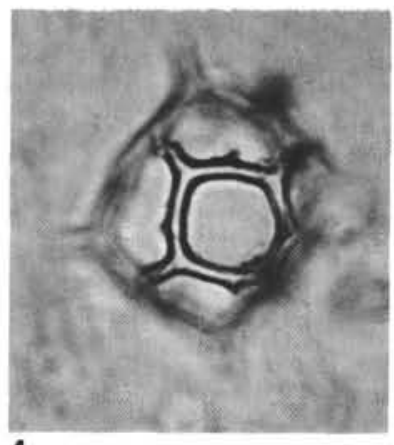

4
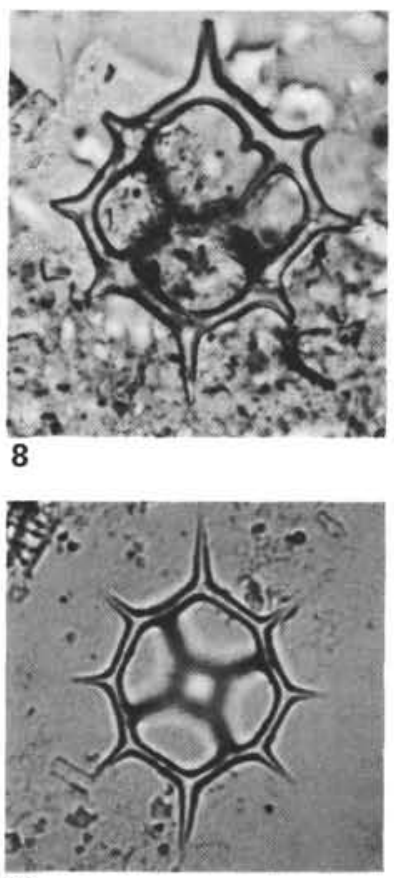

10

Plate 6. Middle Miocene to Quaternary silicoflagellates. (All specimens magnified $\times 800, b a r=10 \mu \mathrm{m}$.) 1-3. Distephanus crux ssp. bispinosus Dumitrică f. bispinosus, $(1,2)$ high and low focus, Sample 591-21,CC, lower Pliocene; (3) Sample 591-24,CC, upper Miocene. 4. Distephanus crux ssp. bispinosus f. mesophthalmus (Ehrenberg), Sample 591-29,CC, upper Miocene. 5. Distephanus aculeatus (Ehrenberg) f. aculeatus, Sample 591-25,CC, upper Miocene. 6, 7. Distephanus crux (Ehrenberg) ssp. crux. (6) Sample 591B-18,CC, middle Miocene; (7) Sample 594A12,CC, middle Miocene. 8. Distephanus stauracanthus f. octagonus (Tsumura), Sample 594-12,CC, Quaternary, allochthonous. 9, 10. Distephanus stauracanthus (Ehrenberg) f. stauracanthus; (9) Sample 591B-16,CC, middle Miocene; (10) Sample 591B-17, CC, middle Miocene. 11, 12. Distephanus aculeatus f. binoculus (Ehrenberg), high and low focus, Sample 591-16,CC, lower Pliocene. 13. Distephanus crux ssp. hannai Bukry, Sample 591B-4,CC, upper Miocene. 


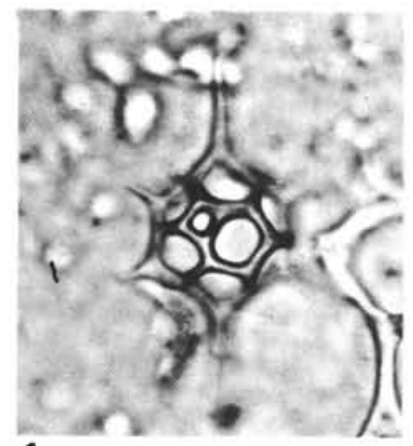

1
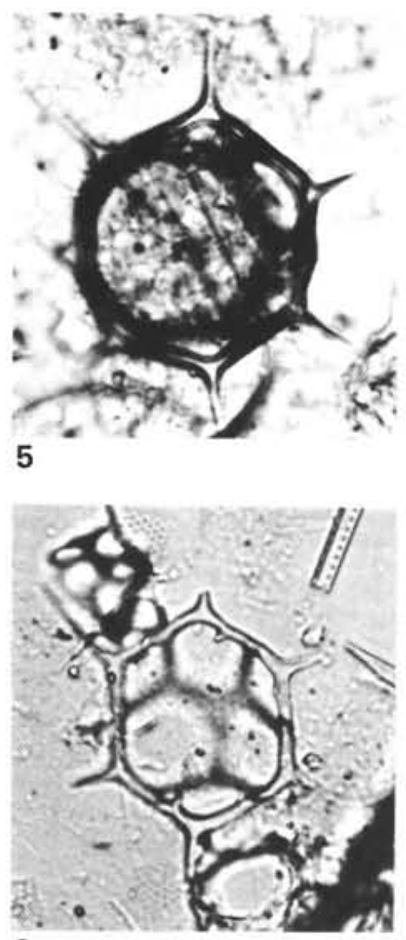

9

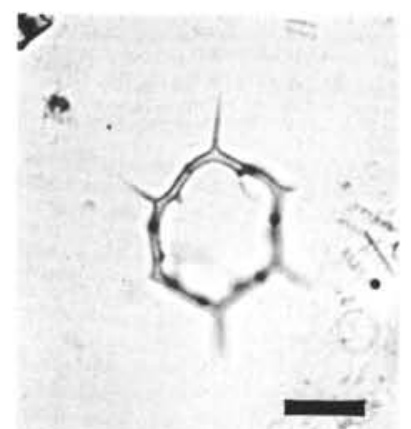

12

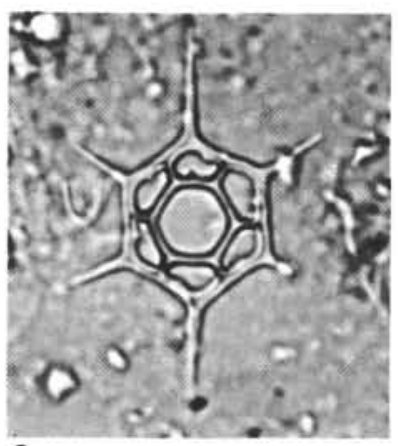

2

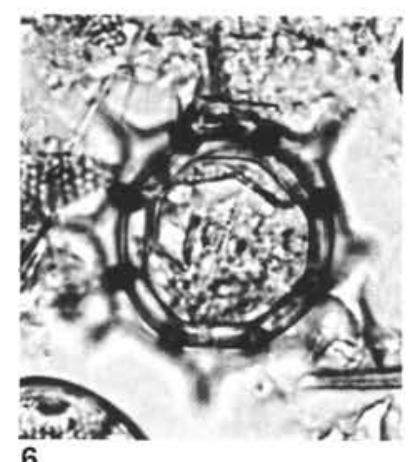

6

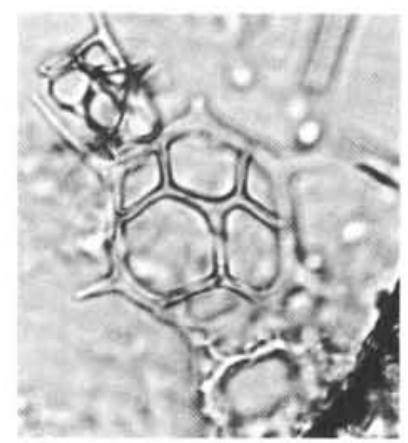

10

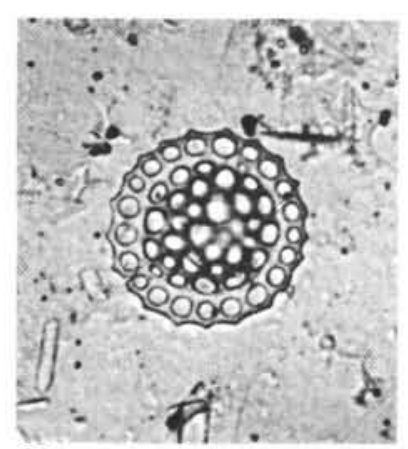

13

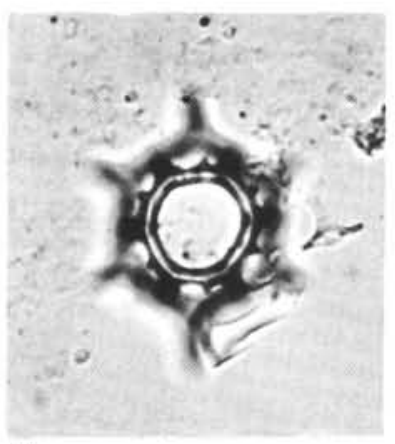

3

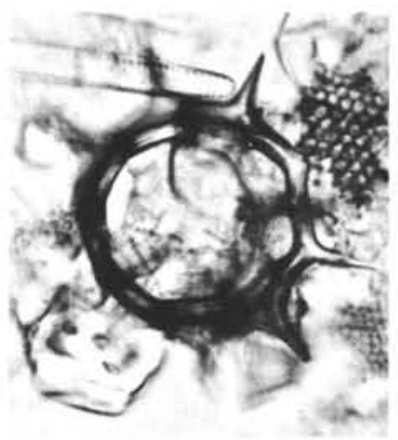

7

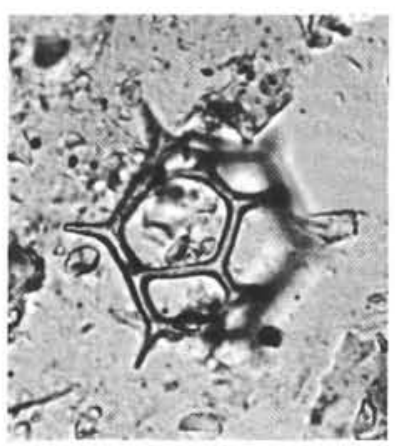

11

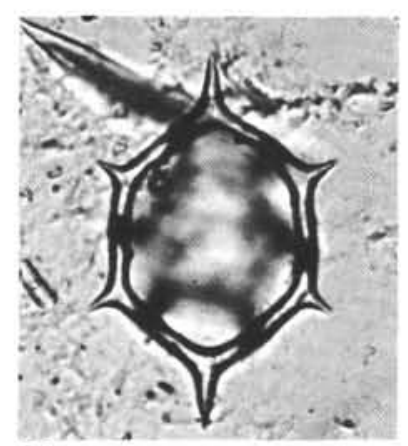

14

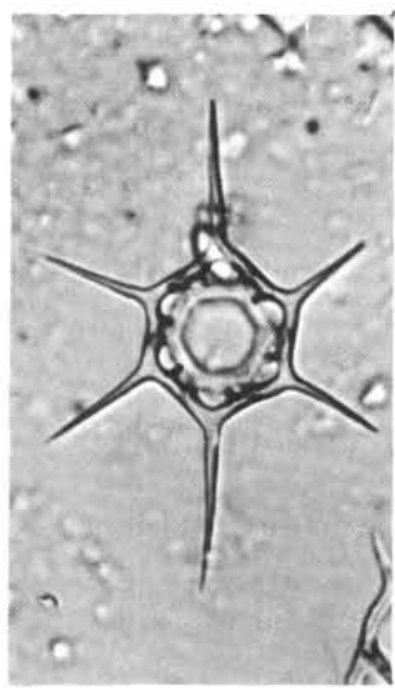

4

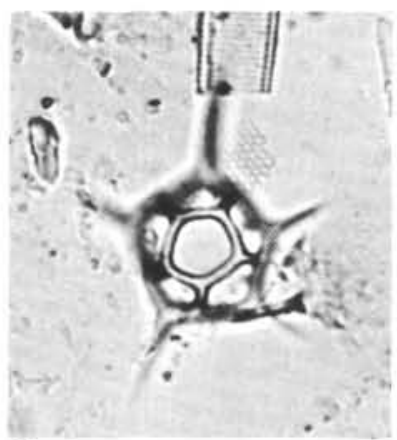

8

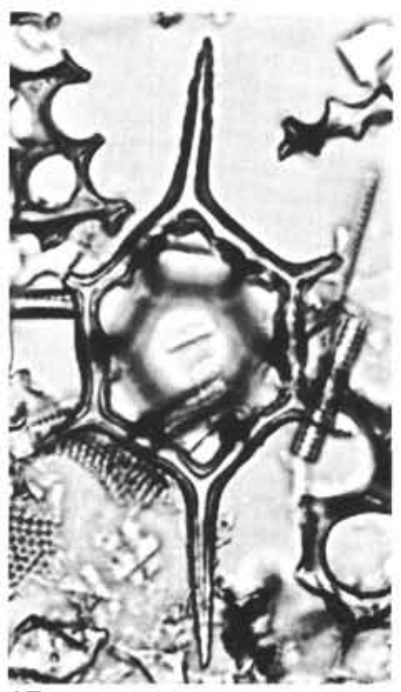

15

Plate 7. Middle Miocene to Quaternary silicoflagellates. (All specimens magnified $\times 800$, bar $=10 \mu \mathrm{m}$.) 1. Distephanus speculum ssp. speculum f. cannopilea-hexacantha (Frenguelli), Sample 591B-1,CC upper Miocene. 2-4. Distephanus speculum (Ehrenberg) ssp. speculum f. speculum, (2) Sample 591-17,CC, lower Pliocene; (3) Sample 594-19,CC, lower Pliocene; (4) Sample 591-21,CC, lower Pliocene. 5. Distephanus speculum ssp. speculum f. septenarius (Ehrenberg), Sample 594-13,CC, Quaternary. 6. Distephanus speculum ssp. speculum f. octonarius (Ehrenberg), Sample 594-13, Quaternary. 7. Distephanus speculum ssp. speculum f. nonarius n.f., holotype SM.B 13510; Sample 594-13,CC, Quaternary. 8. Distephanus speculum ssp. speculum f. pentagonus (Lemmermann), Sample 591-21,CC, lower Pliocene. 9, 10. Distephanus speculum ssp. speculum $\mathrm{f}$. varians Gran and Braarud, high and low focus, Sample 591-20,CC, lower Pliocene. 11. Distephanus speculum ssp. speculum $\mathrm{f}$. pseudofibula Schulz, Sample 594-21,CC, lower Pliocene. 12. Distephanus sp., Sample 591-29,CC, upper Miocene. 13. Macrora stella (Azpeitia), a synuracean sklerite, Sample 591B-17,CC, middle Miocene. 14, 15. Distephanus speculum ssp. giganteus Bukry f. giganteus, (14) Sample 591B-21,CC, middle Miocene; (15) Sample 594-27,CC, upper Miocene. 

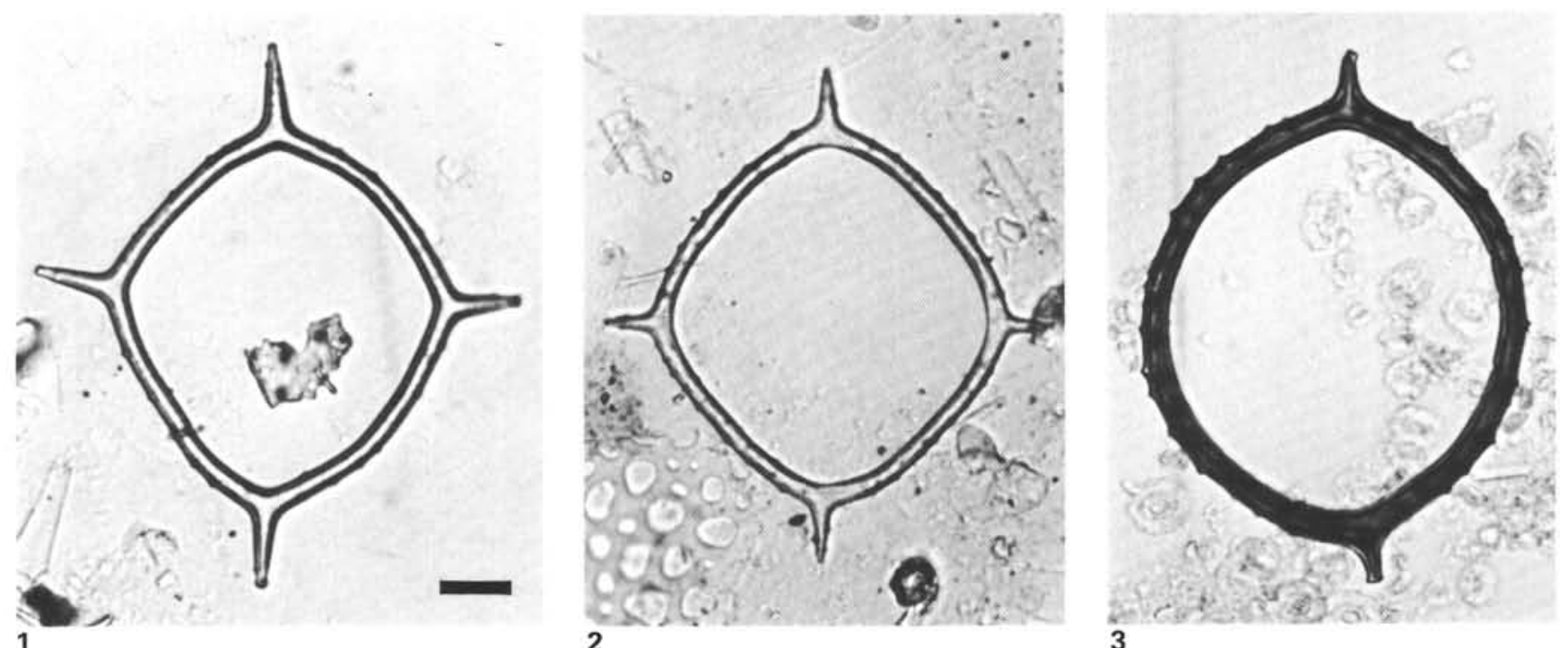

2

3
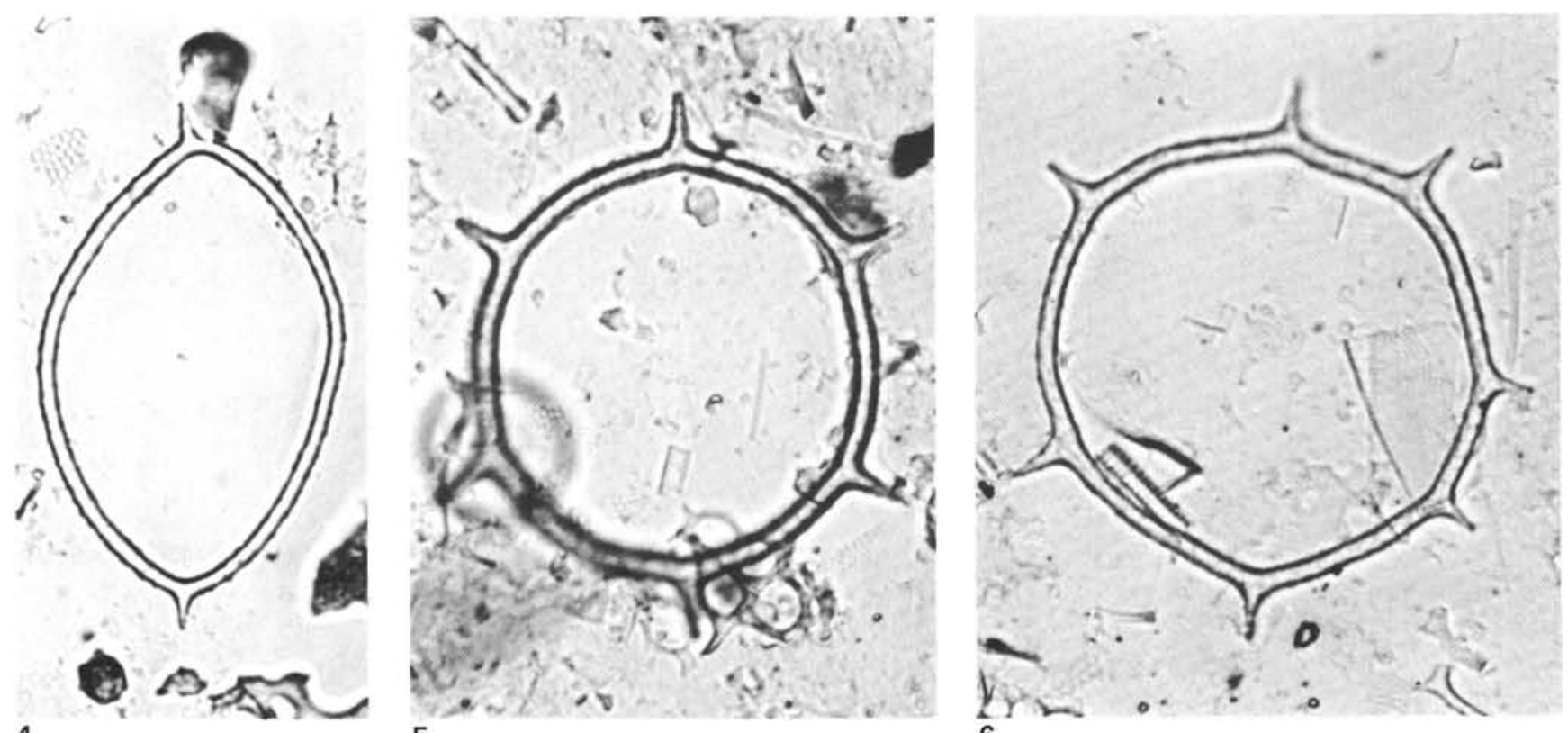

5

6

Plate 8. Middle Miocene to lower Pliocene silicoflagellates. (All specimens magnified $\times 800$, bar $=10 \mu \mathrm{m}$.) 1, 2. Mesocena quadrangula Ehrenberg ex Haeckel, (1) Sample 591-18,CC, lower Pliocene; (2) Sample 591-20,CC, lower Pliocene. 3, 4. Mesocena diodon Ehrenberg, (3) Sample 594-29, CC, middle Miocene; (4) Sample 591B-15,CC, middle Miocene. 5. Mesocena? hexalitha Bukry f. hexalitha, Sample 591-30,CC, upper Miocene. 6. Mesocena? hexalitha f. heptalitha n. f., holotype SM.B 13511, Sample 591-30,CC, upper Miocene. 

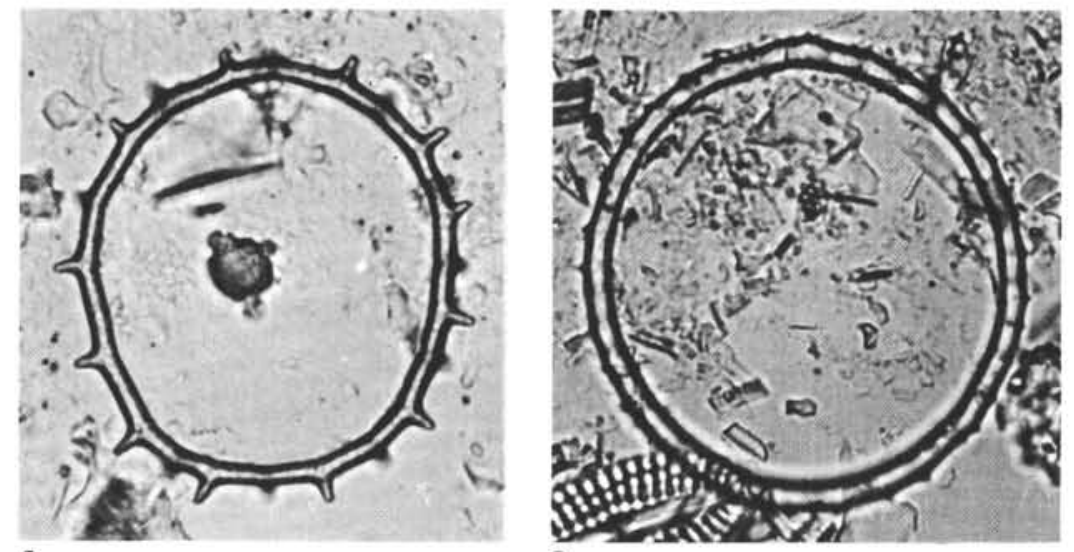

1

\section{2}
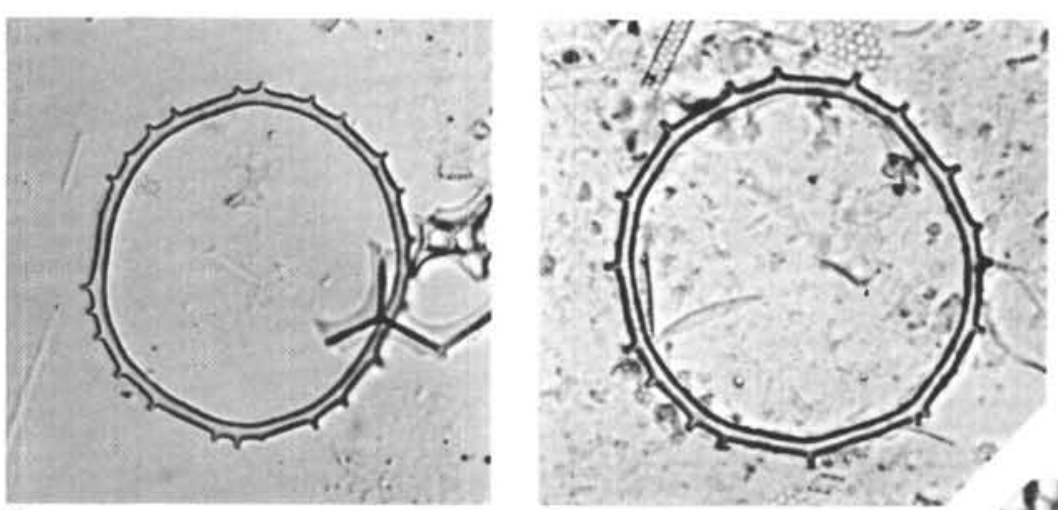

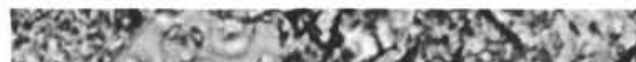

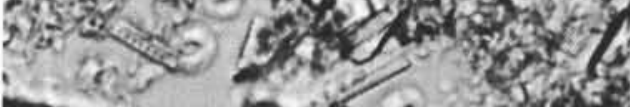

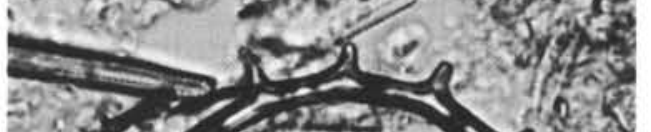

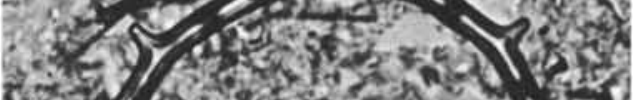

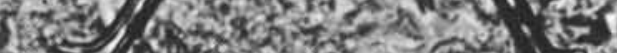

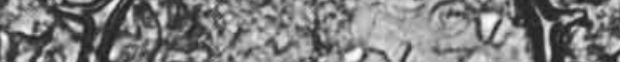
18 (2)

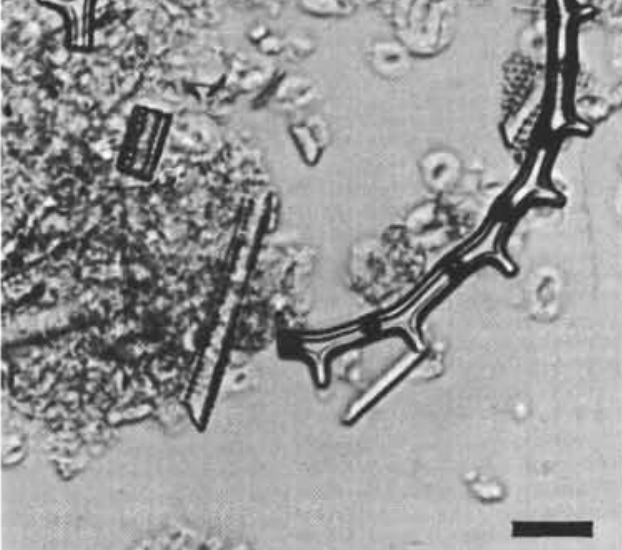

5

3

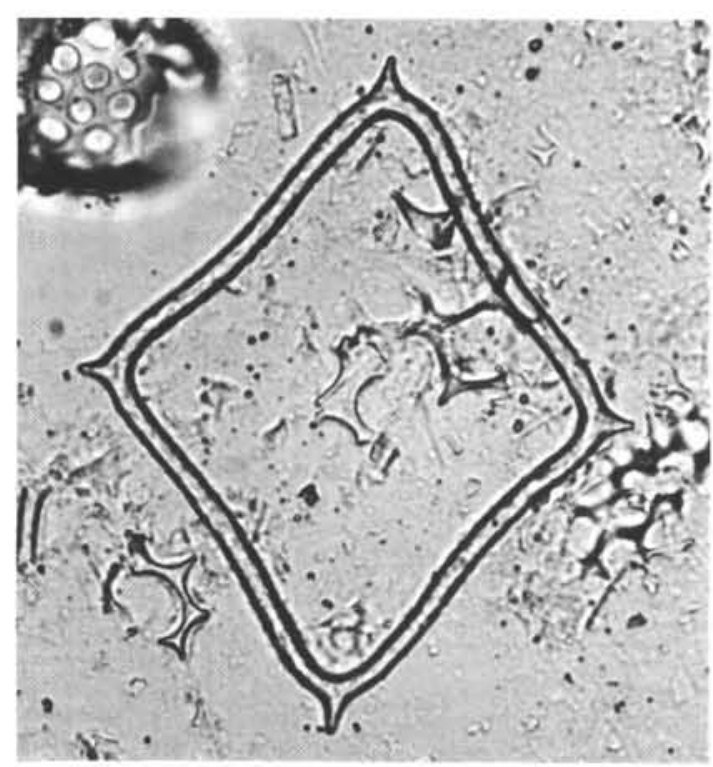

6

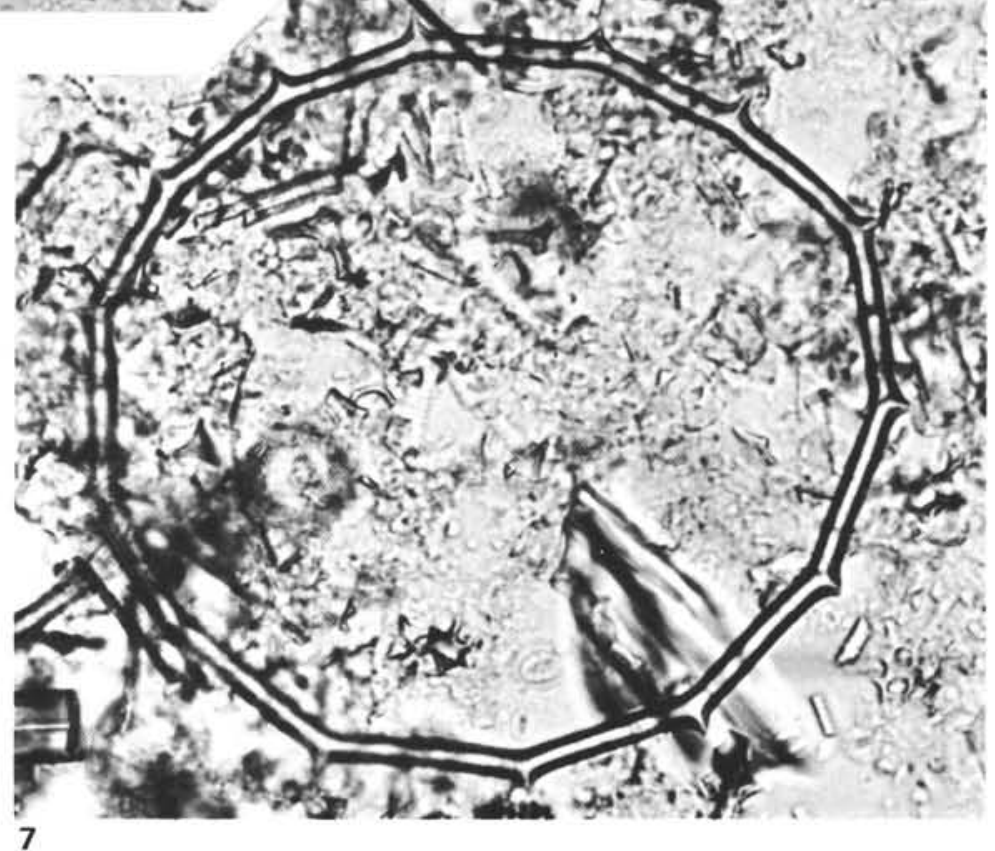

Plate 9. Middle Miocene to lower Pliocene silicoflagellates. (All specimens magnified $\times 800$, bar $=10 \mu \mathrm{m}$.) 1, 5. Paramesocena apiculata (Lemmermann), (1) Sample 591B-9,CC, upper Miocene; (5) Sample 594-28,CC, upper Miocene. 2-4. Paramesocena circulus (Ehrenberg), (2) Sample 594-25,CC, upper Miocene; (3) Sample 591-18,CC, lower Pliocene; (4) Sample 591-18,CC, lower Pliocene. 6. Mesocena elliptica Ehrenberg, Sample 591B-20,CC, middle Miocene. 7. Paramesocena dumitricae (Perch-Nielsen), Sample 594-26,CC, upper Miocene. 


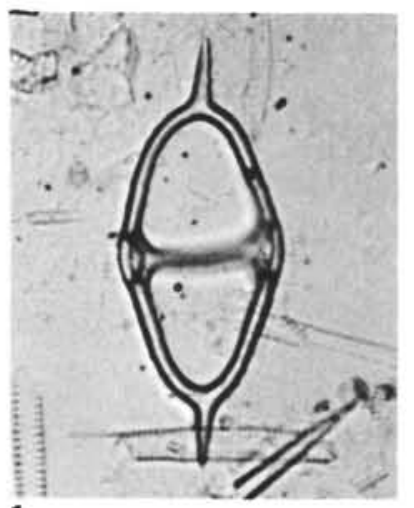

1

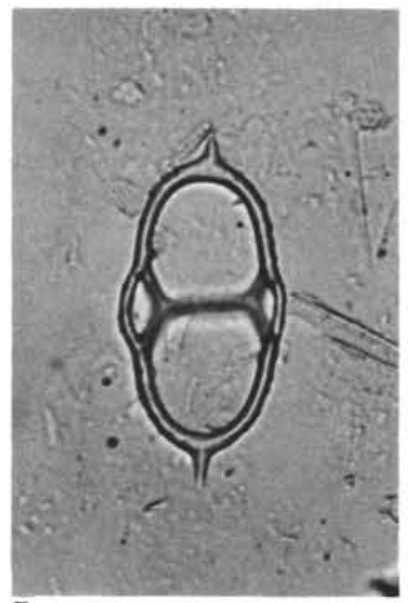

5

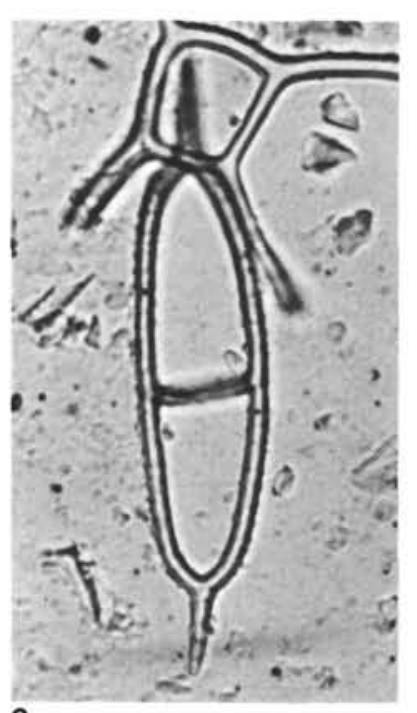

9

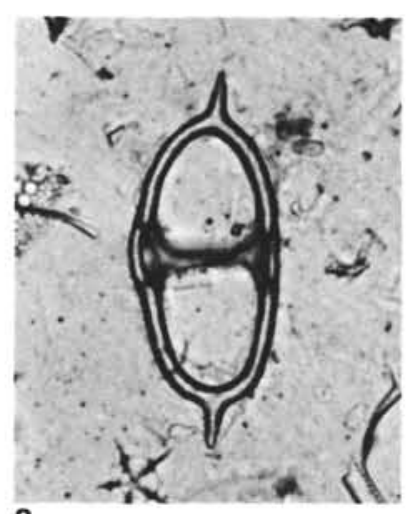

2
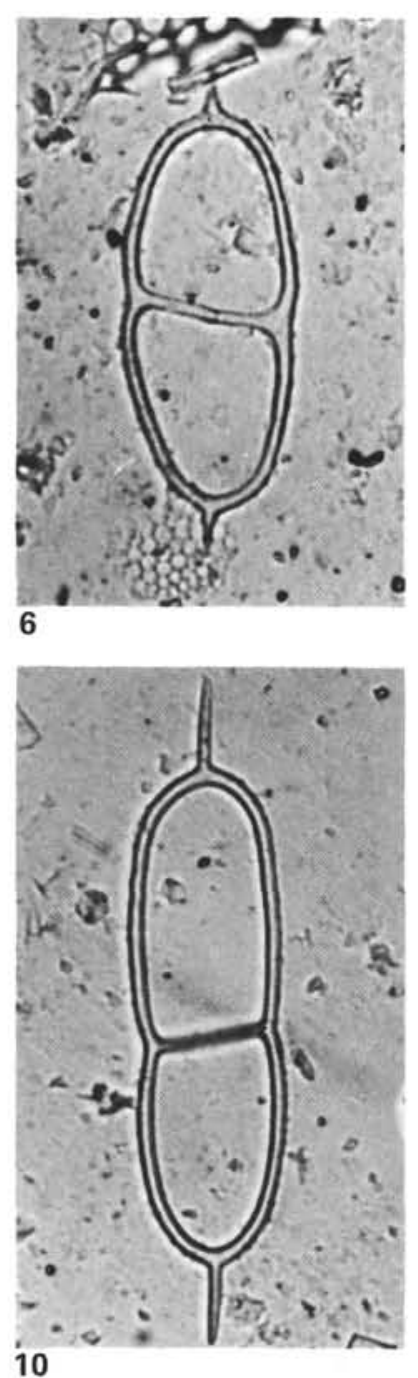

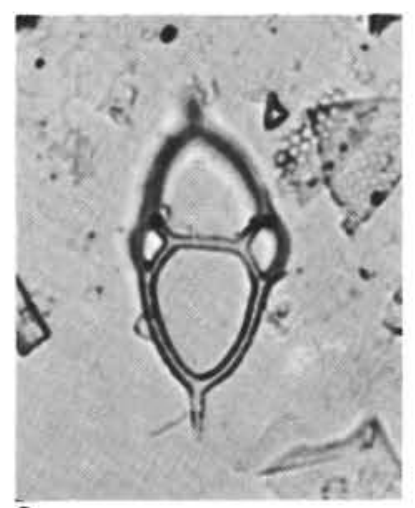

3

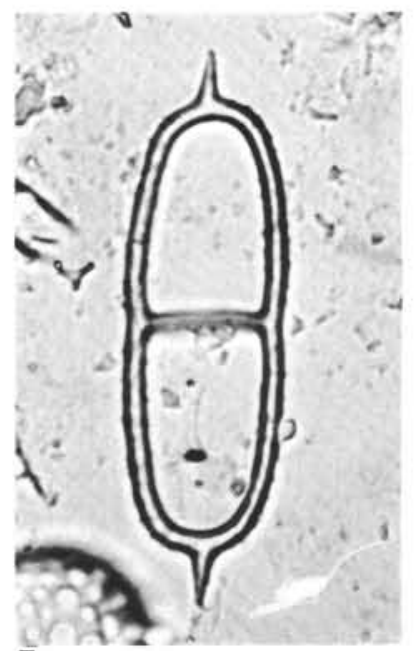

7

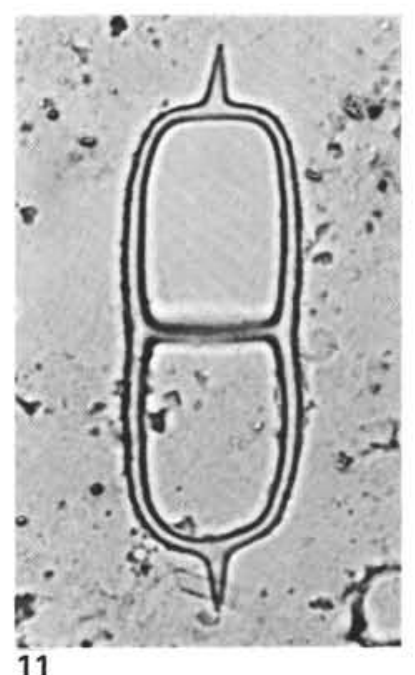

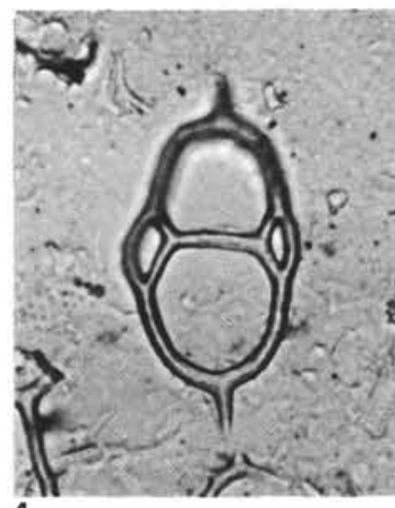

4

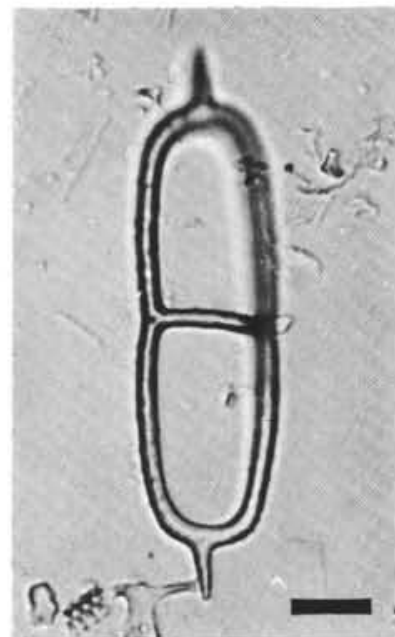

8

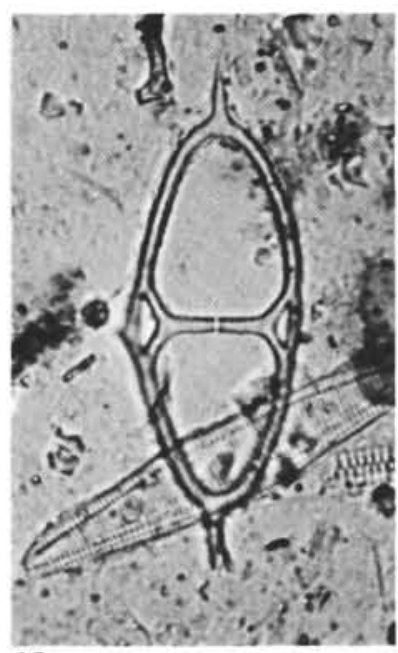

12

Plate 10. Upper Miocene to lower Pliocene silicoflagellates. (All specimens magnified $\times 800, b a r=10 \mu \mathrm{m}$.) 1-5. Neonaviculopsis neonautica ssp. praenautica n. ssp., (1, 2, 4) Sample 591-29,CC, upper Miocene; (3) Sample 591-28,CC, upper Miocene; (5) holotype SM.B 13512, Sample 591-29, CC, upper Miocene. 6-11. Neonaviculopsis neonautica (Bukry) ssp. neonautica f. neonautica, (6-8) Sample 591-23,CC, lower Pliocene; (9-11) Sample 591-22,CC, lower Pliocene. 12. Neonaviculopsis neonautica (Bukry) ssp. neonautica f. praenautica, Sample 591-23,CC, lower Pliocene. 


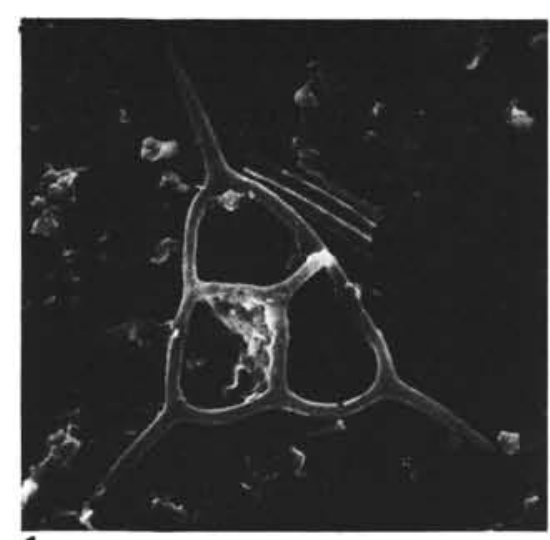

1

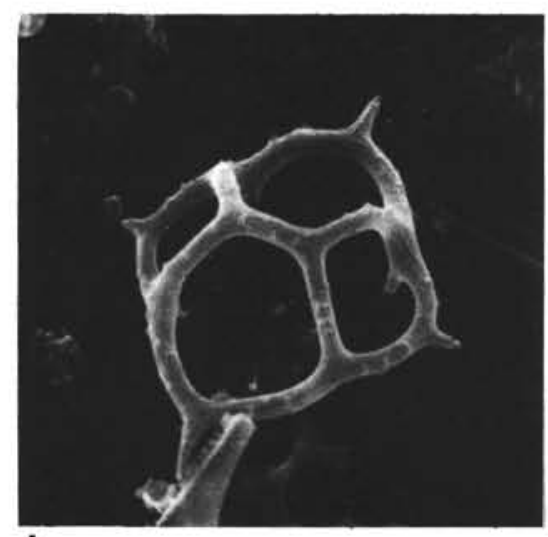

4

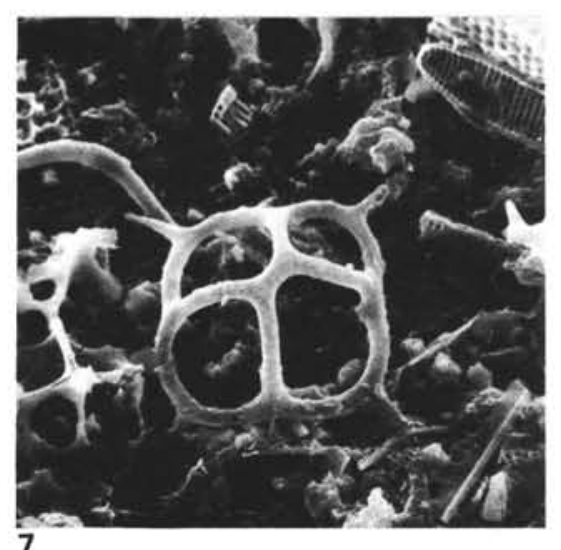

7

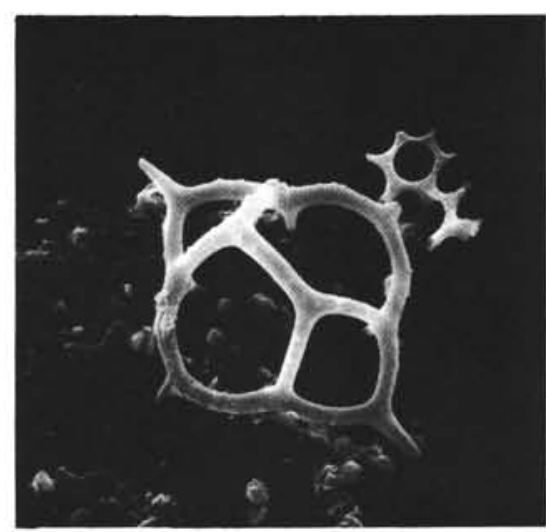

2

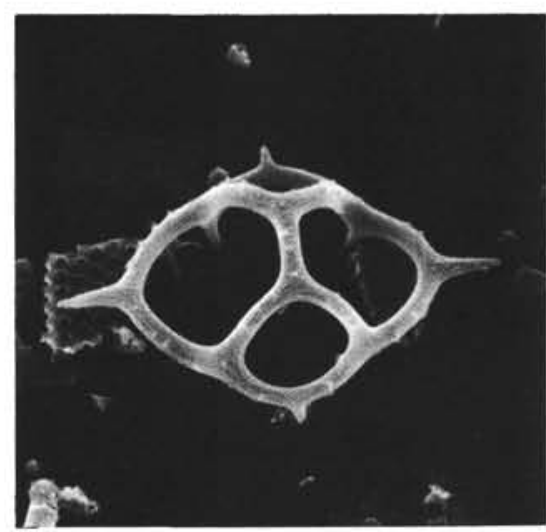

5

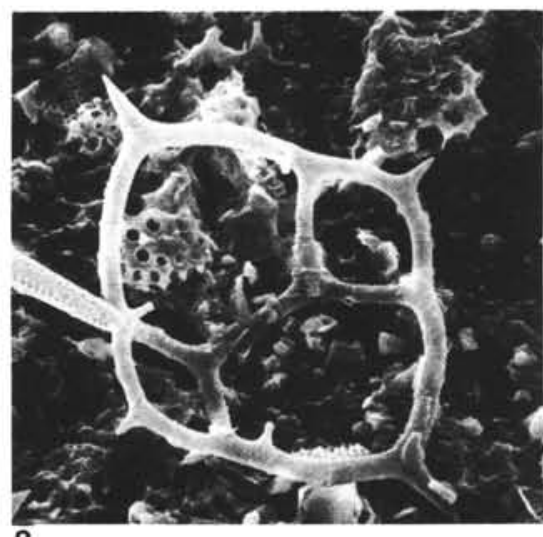

8

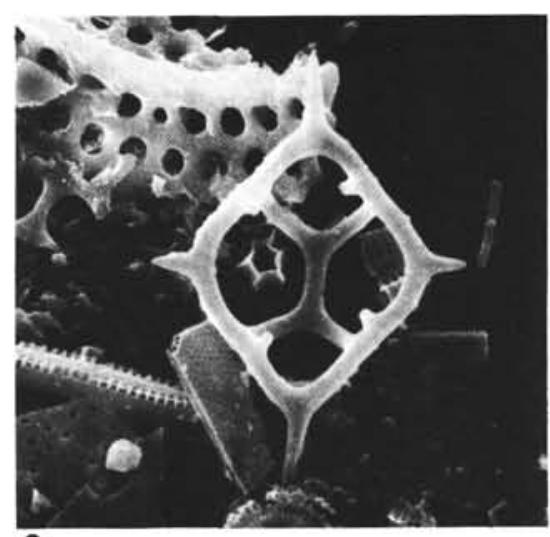

3

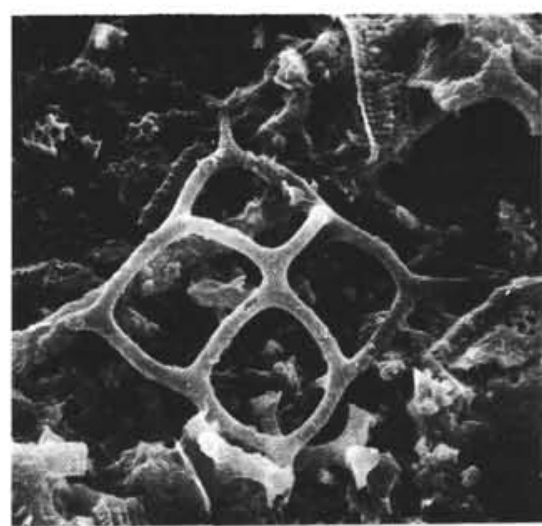

6

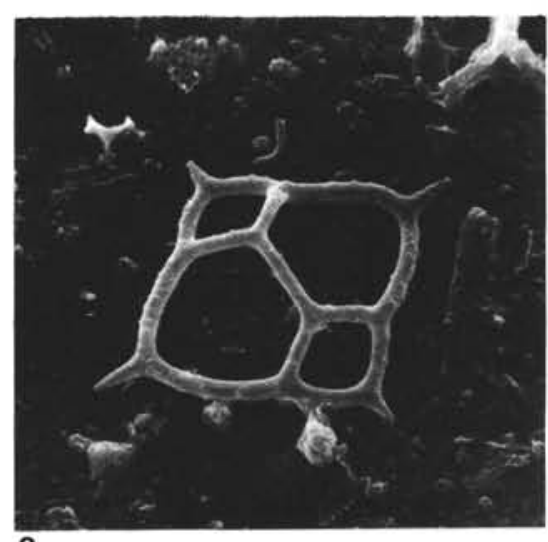

9

Plate 11. Middle Miocene to Lower Pliocene silicoflagellates (Scanning electron micrographs.) 1. Corbisema triacantha (Ehrenberg), apical view, $1200 \times$; Sample 591B-18,CC, middle Miocene. 2. Dictyocha messanensis ssp. stapedia (Haeckel) f. aspinosa, apical view, 1300 ×; Sample 59118,CC, lower Pliocene. 3. Dictyocha extensa (Locker), antapical view, 1200×; Sample 591-29,CC, upper Miocene. 4, 5. Dictyocha varia Locker, (4) apical view, $1800 \times$, Sample 591-20,CC, lower Pliocene; (5) apical view, 1500×, Sample 591-20,CC, lower Pliocene. 6. Dictyocha medusa Haeckel, apical view, $1200 \times$; Sample 591B-4,CC, upper Miocene. 7. Dictyocha sp. 2, apical view, 1200×; Sample 591B-4,CC, upper Miocene. 8, 9. Dictyocha fibula Ehrenberg ssp. fibula, (8) antapical view, $1100 \times$, Sample 591B-4,CC, upper Miocene; (9) apical view, 1050×, Sample 591-29,CC, upper Miocene. 


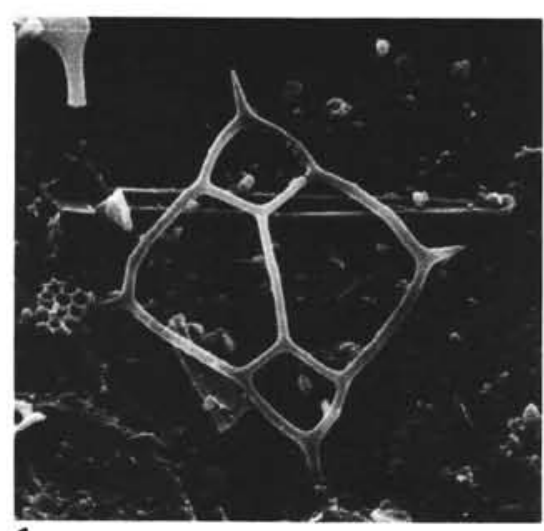

1

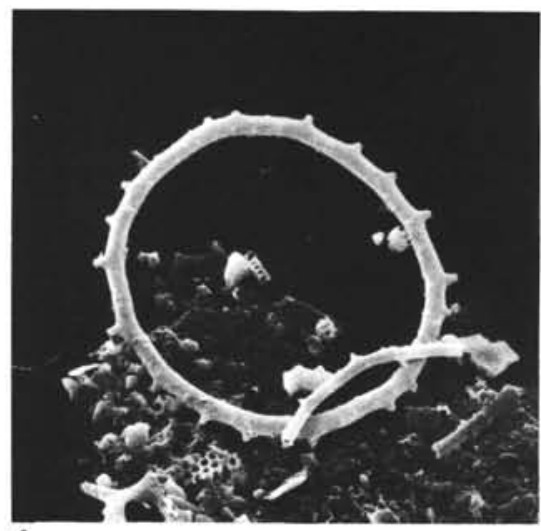

4

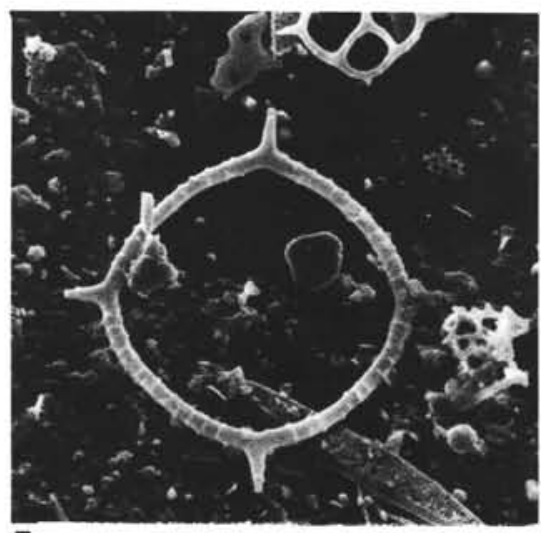

7

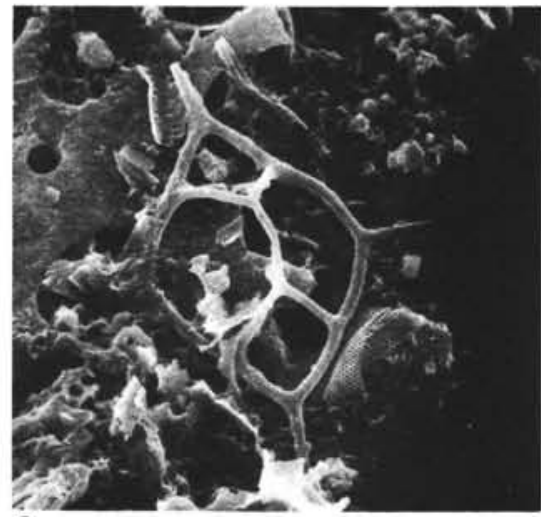

2

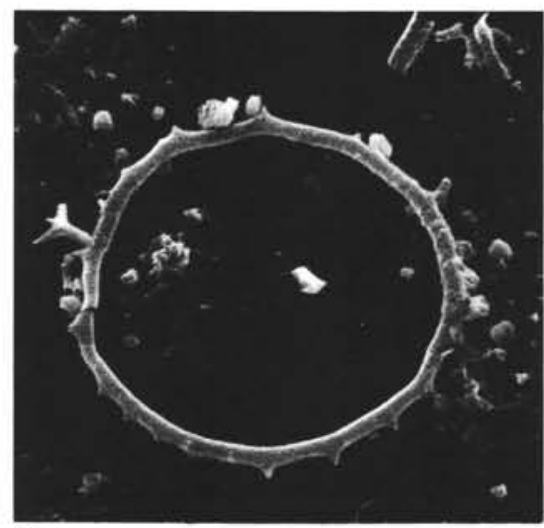

5

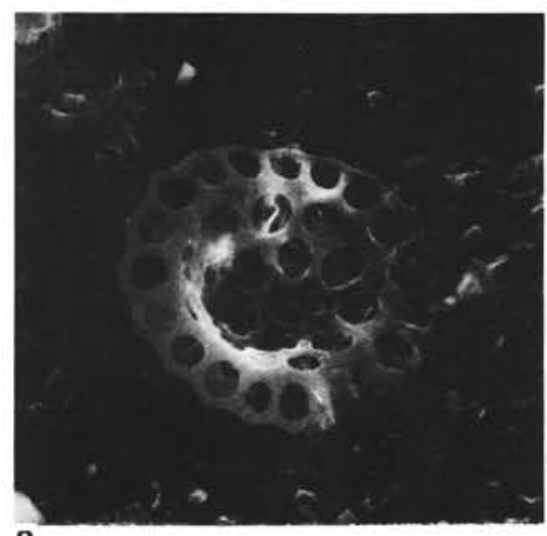

8

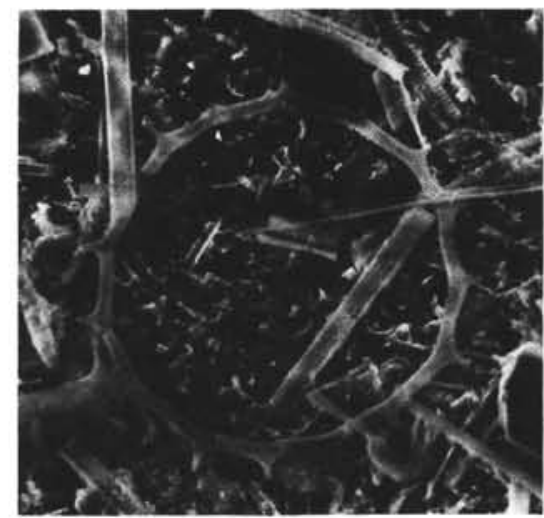

3

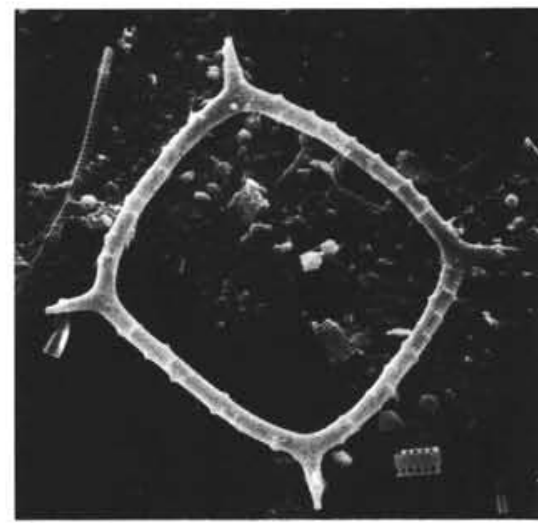

6

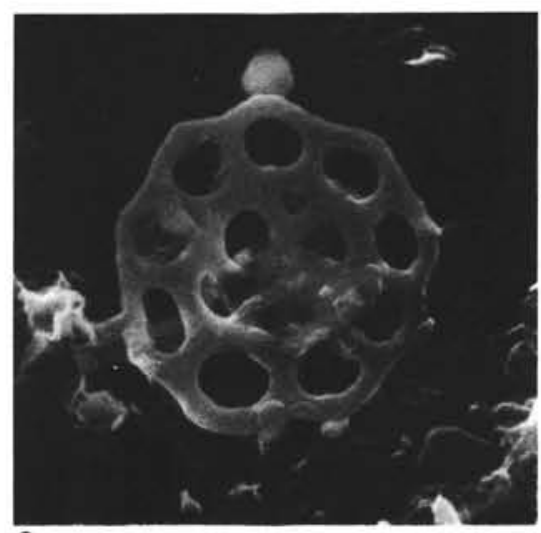

9

Plate 12. Middle Miocene to Lower Pliocene silicoflagellates. (Scanning electron micrographs.) 1. Dictyocha perlaevis Frenguelli f. perlaevis, $900 \times$; Sample 591-20,CC, lower Pliocene. 2. Dictyocha messanensis ssp. aspinosa (Bukry), 1200×; Sample 591B-7,CC, upper Miocene. 3. Paramesocena apiculata (Lemmermann), 650x; Sample 594-28,CC, upper Miocene. 4, 5. Paramesocena circulus (Ehrenberg), 1050 $\times$ and $1100 \times$; Sample 591-18,CC, lower Pliocene. 6, 7. Mesocena quadrangula Ehrenberg ex Haeckel, $1000 \times$ and 550×; Sample 591-20,CC, lower Pliocene. 8, 9. Macrora stella (Azpeitia), $1400 \times$ and 3500 $\times$; Sample 591B-20,CC, middle Miocene. 


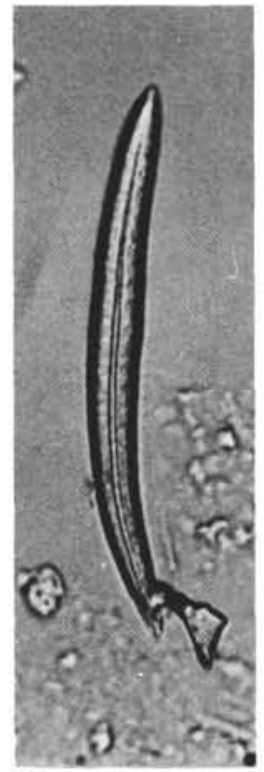

1

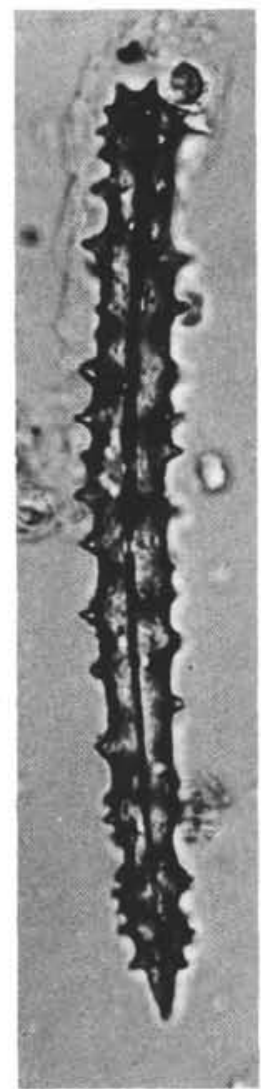

11

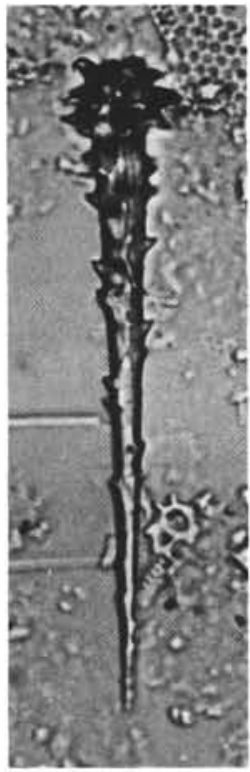

2

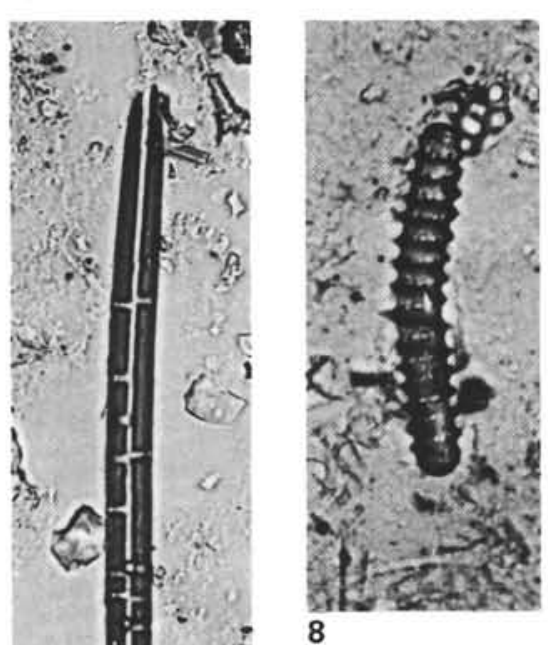

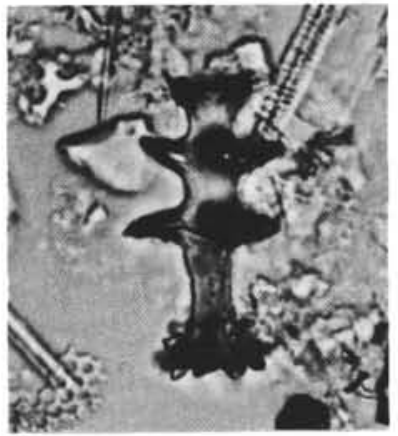

4

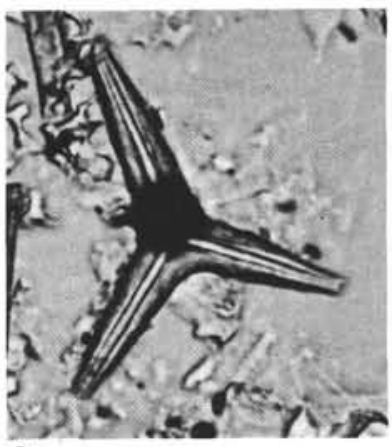

6

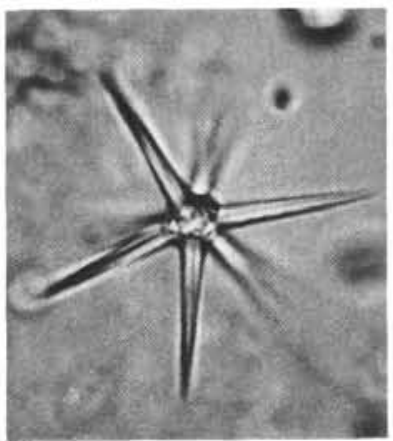

9

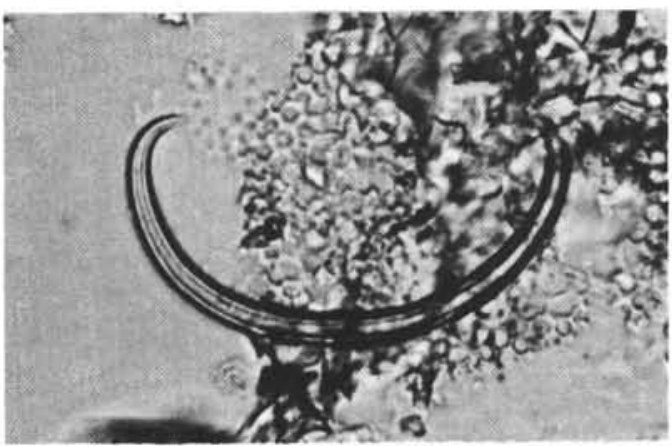

13

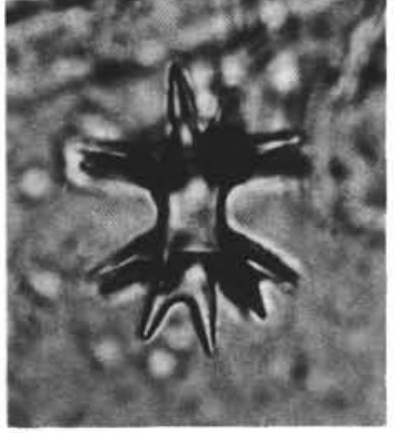

5

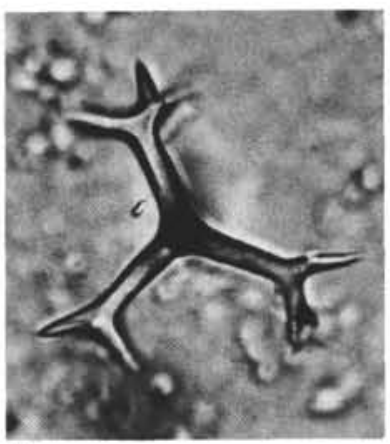

7

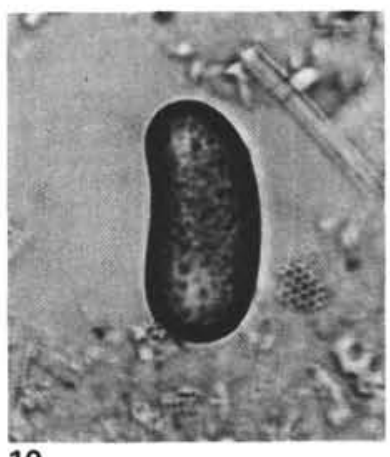

10

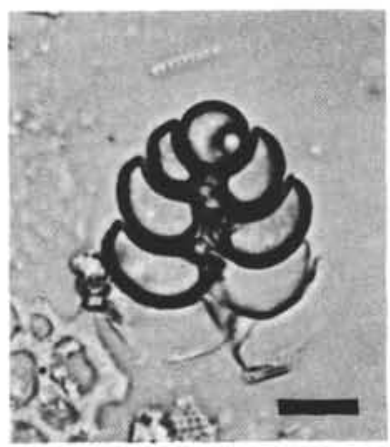

14

Plate 13. Middle Miocene to lower Pliocene sponge spicules; terminology according to Rauff, 1893/94. (All specimens magnified $\times 800$, bar $=10$ $\mu \mathrm{m}$.) 1. Amphiox, Sample 591-29,CC, upper Miocene. 2. Acanthostyl, Sample 591-31,CC, upper Miocene. 3. Spirul, Sample 591-31,CC, upper Miocene. 4. Discorabd, Sample 594-47,CC, middle Miocene. 5. Amphiaster, Sample 591-31,CC, upper Miocene. 6. Oxycalthrop, Sample 594A-17,CC, middle Miocene. 7. Calthrop with branched terminations, Sample 591-18,CC, lower Pliocene. 8. Criccostrongyl, Sample 591B-2,CC, upper Miocene. 9. Oxyaster, Sample 591-17,CC, lower Pliocene. 10. Nephroid rhax, Sample 591-20,CC, lower Pliocene. 11. Acanthostyl, Sample 594-18,CC, lower Pliocene. 12. Amphiox with short accessary channels, Sample 594A-18,CC, middle Miocene. 13. Hooked amphiox, Sample 594A-12,CC, middle Miocene. 14. Silicified biserial foraminifer, Sample 591-26,CC, upper Miocene. 